\title{
MASTER BNL.-50552
}

FUTURE RESIDENTIAL AND COMMERCIAL ENERGY DEMAND IN THE NORTHEAST

John Lee

March 1976

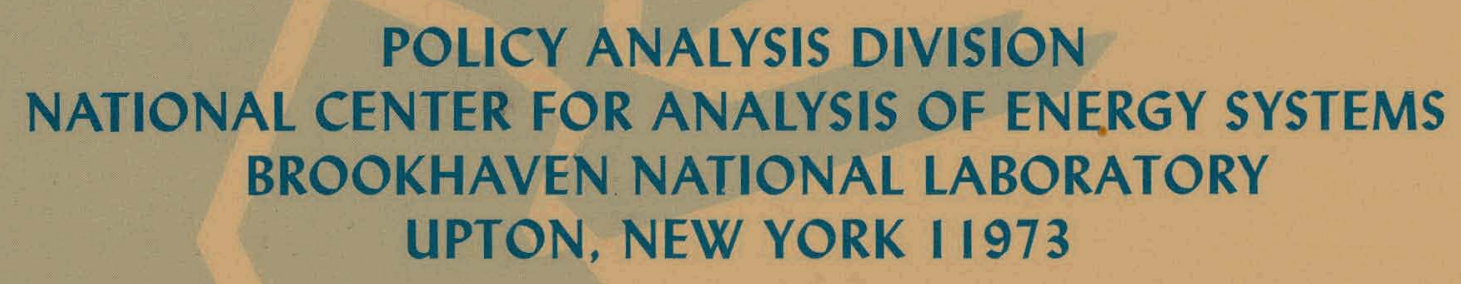

Prepared for the

UNITED STATES ENERGY RESEARCH AND DEVELOPMENT ADMINISTRATION 


\section{DISCLAIMER}

This report was prepared as an account of work sponsored by an agency of the United States Government. Neither the United States Government nor any agency Thereof, nor any of their employees, makes any warranty, express or implied, or assumes any legal liability or responsibility for the accuracy, completeness, or usefulness of any information, apparatus, product, or process disclosed, or represents that its use would not infringe privately owned rights. Reference herein to any specific commercial product, process, or service by trade name, trademark, manufacturer, or otherwise does not necessarily constitute or imply its endorsement, recommendation, or favoring by the United States Government or any agency thereof. The views and opinions of authors expressed herein do not necessarily state or reflect those of the United States Government or any agency thereof. 


\section{DISCLAIMER}

Portions of this document may be illegible in electronic image products. Images are produced from the best available original document. 
BNL 50552

[General, Miscellaneous, and Progress

Reports (Nonnuclear) - TID-4500]

\title{
FUTURE RESIDENTIAL AND COMMERCIAL ENERGY DEMAND IN THE NORTHEAST
}

\author{
JOHN LEE
}

March 1976

Würk suppurted by the Dlvision of Biomedical and Environmental Research of the United States Energy Research and Development Administration under Contract No. E(30-1)-16 in the context of the Brookhaven National Laboratory Regional Energy Studies Program.

POLICY ANALYSIS DIVISION

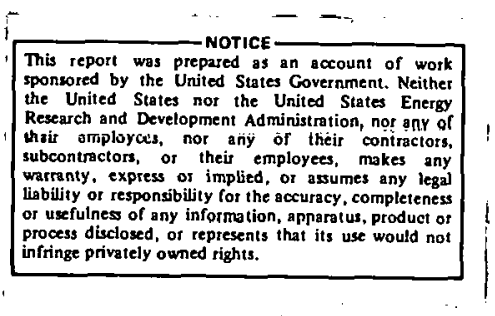

NATIONAL CENTER FOR ANALYSIS OF ENERGY SYSTEMS

BROOKHAVEN NATIONAL LABORATORY

UPTON, NEW YORK 11973 


\section{1}

NOTICE

This report was prepared as an account of work sponsored by the United States Government. Neither the United Stales nor the Unitcd States Energy Research and nevelnpment Administration, nor any of their employees, nor any of their contractors, subcontractors, or their employees, makes any warranty, expless or iniplicd, or assumes any legal liability or responsibility for the accuracy, completeness or usefulness of any information, apparatus, product or process disclosed, or represents that its use would not infringe privately owned rights.

\section{Printed in the United States of America \\ Available from \\ National Technical Information Service \\ U.S. Department of Commerce \\ 5285 Port Royal Koad \\ Springfield, VA 22161}

Price: Printed Copy $\$ 6.00$; Microfiche $\$ 3.00$ 
FOREWORD

This report is one of a number of issue papers prepared as part of the Brookhaven National Laboratory Northeast Energy Perspectives study. The analyses in these papers were performed specifically to assist us in our first integrated study of the energy future of the northeastern united states.

Topics covered by the issue papers include the potential supply. of energy to the Northeast from coal, oil, natural gas, liquefied natural gas (LNG), nuclear power, municipal waste, solar i energy, and wind power, and the demand for energy in the Northeast from the industrial, transportation, and residential and" commercial sectors. In each case a range of estimates of energy supply or demand was constructed to reflect not only a variety of possible policy and technological developments, but also the. basic uncertainties of all such future projections. The integrative analysis which relates the supply and demand picture is presented in "A Perspective on the Energy Future of the Northeast United States."

The issue papers prepared for the Northeast Energy Perspectives study and the summary report, will be available from:

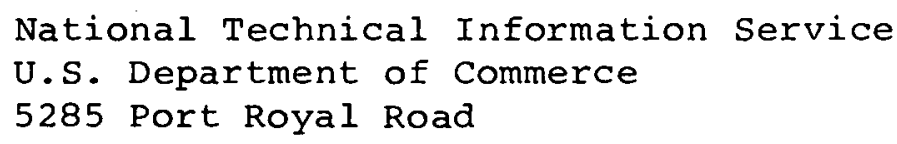

The issue papers and summary report are listed below. 
H. Bronheim, "Future Oil Supply to the Northeast United States," BNL 50557 (June 1976).

R. J. Goettle, IV, "Alternative Patterns of Industrial Energy Consumption in the Northeast," BNL 50555 (March 1976).

R. N. Langlois, "Future Natural Gas Supply to the Northeast," BNL 50558 (April 1976).

J. Lee, "Future Residential and Commercial Energy Demand in the Northeast," BNL 50552 (March 1976).

P. M. Meier and T. H. MCCoy, "Solid Waste as an Energy Source for the Northeast," BNL 50559. (June 1976).

P. M. Meier, T. H. MCCoy, and S. Rahman, "Issues in the Future Supply of Electricity to the Northeast," BNL 50553 (June 1976).

B.: S. Edelston and E. S. Rubin, "Current and Future Use of Coal in the Northeast," BNL 50560 (May 1976), Environmental Studies Institute, Carnegie-Mellon University, Pittsburgh, Penn.

V. L. Sailor and F. J. Shore, "The Future of Nuclear Power in the Northeast," BNL 50551 (March 1976).

G. R. Bray, S..K. Julin and J. A. Simmons, "Supply of Liquefied Natural Gas to the Northeast," BNL 50556 (April 1976), Science Applications, Inc., 1651 Old Meadow Road, McLean, Va.

System Design Concepts, Inc., "Transportation Energy Consumption and Conservation Policy Options in the Northeast." BNL 50554 (April 1976), System Design Concepts, Inc., 9 Rector Street, New York, I.Y. Y. 10006.

J. Brainard et al., Editors, "A Perspective on the Energy Future of the Northeast United States," BNL 50550 (June I976). 


\section{ABSTRACT}

In 1972 the Northeast consumed 5.02 quadrillion Btu's (quads) or $44 \%$ of its energy use in the residential and commercial sectors. of this total, about two-thirds ( 3.30 quads) was consumed in residential households and the balance ( 1.72 quads) in commercial buildings. By end use, space heating is dominant in both sectors, accounting for about $71 \%$ of the energy used in the residential sector and $76 \%$ in the commercial sector. In terms of fuel distribution, both sectors are highly dependent on oil, with more than half of their energy supplied from petroleum products.

Based on existing demographic projections and considering different levels of change in technology, government policy, consumer behavior, and related factors, three alternative energy consumption patterns were constructed for 1985 and 2000. The Base Case projections, which assume a continuation of the consumption patterns which have developed since the "energy crisis" of 1973-74, indicate a total residential energy use in the region that remains roughly at the 1972 level until 1985. This consumption is projected to increase at an annually compounded growth rate of $0.6 \%$ from 1985 to 2000. The commercial energy demand is projected to grow at an annual rate of $2.7 \%$ between 1972 and 1985 and $4.1 \%$ between 1985 and 2000 .

The conservation scenarios indicate that there is a tremendous potential for energy conservation in the two sectors. Universal application of technology which is currently available at reasonable cost and slight alterations of life style would reduce the average energy growth in the combined residential and commercial sectors from an annual rate of $1.7 \%$ to almost zero growth between 1972 
and 2000. A more severe conservation case which assumed direct governmental intervention, maximum utilization of current technology, and some public sacrifice of convenience and changes in lifestyle could reduce the energy consumption in 2000 to about the 1972 level. 
CONTENTS

I. Summary • • •

A. Introduction . . . . : . . . . . . . 1

B. Base Year (1972) Energy Consumption . . . . 3

C. 1985 and 2000 Energy Demand - Base Case . . . 5

1. Residential Growth Rates . . . . . . . 5

2. Commercial Energy Growth • • • • • • 8

D. The Potential for Energy Conservation • - • . 8

II. Residential Energy Demand Projections • • • • • 13

A. Methodology • • . • • • • • • • . . 13

B. Residential Inventory and Projections . . . . . 13

1. Base-year (1972) Inventory . • • . . . " 13

2. Population and Households • • • • • . 15

3. 1985 and 2000 Inventory - • • • • • • 15

C. Unit Demand and Saturation by End Use • • • 17

III. Commercial Energy Demand Projections. • . . • •

A. Methodology • • • • • • • • • • . . 21

B. Commercial Inventory and Projections • • • •. 21

1. 1972 Floor-space Inventory • • • • . . . 21

2. Commercial Floor-space Projections -

C. Unit Demand by End Use . • • • • • • • • • 25

IV. Energy Impacts of Conservation Measures • • • • 27

A. Conservation and Demand Projections. . . . 27

1. Base Case • • . • . . . . . • . 27

2. Moderate Conservation Case - . . . . . 28

3. Strong Conservation Cáse * • . . . • 28

B. Measures for Reducing Energy Consumptions • • 29

Áppendix A. Fuel Mix Tables . • . . • • • • $\quad 37$

Appendix B. Mode Shift Analysis . • . • • : . . 127 
1. Summary of Residential and Commercial End Use of Energy, 1972

2. 'Summary of Residential and Commercial Energy Consumption by Fuel Type, 1972 • • • • • • • • 4

3. 1985 Northeast Residential and Commercial Energy DemandBase Case - • • • • • • • • • • • • • • 6

4. 2000 Northeast Residential and Commercial Energy Demand, Base Case . . . • • . • . . . . . 6

5. Summary of Region I Residential and Commercial Energy Demands by Fuel Type, 3.985 and $2000 \ldots . . . . . .10$

6. Summary of Region II Residential and Commercial Energy Demands by Fuel Type, 1985 and 2000 - . . . . . 11

7. Summary of Region III Residential and Commerical Energy Demands by Fuel Type, 1985 and 2000 • • . . . . 11

8. Summary of Northeast Region Residential and Commercial Energy Demands by Fuel Type, 1985 and 2000 • • • . 11

9. Summary of Residential End Use by Housing Type and Fuel, 1972

10. Population by Region.

11. Number of Persons Per Household, Historical and Projected 16

12. Residential Inventory - • • • • • • • • • • 18

13. Annual Unit Demand for Residential End Uses, Except

Lighting and Miscellaneous Appliances • : • • 19

14. Annual Unit Demand and Saturation for Lighting and Miscellaneous Electric Appliances . • • • • • . 19

15. New Commercial Floor Space Construction in the U.S. • . 24 16. Commercial Floor Space Inventory . • • . . . . . . 24

17. 1972 Commercial Unit Demand by End Use, Northeast Region 25

18. Summary of Conservation Scenarios - • • • • • • • 30

A-1 to A-86. Fuel Mix Tables, Residential and Commercial sectors, Regions I to III • • . . • • •

B-1. Northeast Residential and Commercial Energy Demand Mode Shift to Electricity . . . . . . . . . . 123

B-2. Northeast Residential and Commercial Energy Demand.Mode Shift to Electricity and Gas • • • . . • . 129

B-3. Northeast Residential and Commercial Energy Demand Mode Shift to Oil and Gas . . . . . . . . . . 129 


\section{LIST OF FIGURES}

Page

1. Energy Growth in the Residential and Commercial Sectors (1972-2000)-Base Case and Conservation

Scenarios

2. Schematic Description of Methodology for Projecting Future Residential Energy Demand. . . . . .

3. Schematic Description of Methodology for Projecting Future Commercial Energy Demand. Euture commercial En 


\section{SUMMARY}

\section{A. Introduction}

The purpose of this report is twofold. First, it presents a range of energy demand projections in the residential and "commer-" cial sectors for the Northeast United Stätes. These projections are an integral part of the Northeast Energy Perspectives study being carried out by the Energy Policy Analysis Division at Brookhaven National Laboratory (BNL) to analyse the major energy issues of the region and the national energy policy issues that require a regional scale of analysis. second, the projections and their underlying data and analysis provide a framework for assessing the regional impact of possible policy changes, technological innovations, and energy conservation strategies.

The region under study covers the New England states (Region I), New York (Region II), Penrisylvania, New Jersey, Delaware, Maryland, and the District of Columbia (Region III). In most cases, projections were made at the subregional level and then aggregated to the total Northeast. ' Since 1972 is the most recent' year for which fairly complete and consistent data are available, it was chosen as the base year in order to provide a reference point for developing the energy demand forecasts for the years 1985 and 2000. Forecasts of regional economic activities are.. based on the 1972 OBERŚ projection. ${ }^{1}$. Other primary sources of information are published reports and documents from government., .. agencies, business associations, and private institutions. In the absence of adequate recorded information, data have been estimated or extrapolated. The methods and sources of data used in making such estimates are given later in this report. 
The basic methodology employed for projecting future residential and commercial energy demands involved two major steps. First, the determinative factors such as housing stock by type and various categories of commercial floor space were projected for the future reference years. These projections were then combined with projected unit energy demands, saturation rates, and fuel mixes in terms of disaggregated end use to establish the total energy requirements for each demand category (e.g., residential space heating). Detailed discussions of the methodologies and data sources used in deriving values tor these fáctors are presented in seuliuns iI and III.

. No single projection of demand can indicate with certainty what will occur in the future. Therefore, in this study several projections were constructed, covering a wide but interesting range of demand possibilities. The three projections included in this report--the base case, a moderate conservation case, and a strong conservation case--were designed to reflect different levels of change in technology, government policy, consumer behavior, and related factors. Section IV describes the detailed assumptions on which these cases were constructed.

Appendix A cuntains a sel of fuel mix tablco for oach subregion: These are worksheets that use the factors generated in Sections II and III to establish the demand projections at the subregional level. The disaggregated format ot the fuel mix tables is required in order to evaluate technologies or conservation measures that may apply to very specific end uses.

Included in Appendix B are summary tables of energy demand by fuel type, developed by assuming some mode shifts between fuels. These mode shift cases were constructed primarily for use in supplydemand analysis in the Northeast Energy Perspectives study and are not discussed in detail. 
This study represents an initial, exploratory effort to develop a regional model for projecting residential and commercial energy demands: Much of the work described in this report is therefore preliminary and subject to refinement or modification. This study should be expanded to include in-depth analyses of the various policy options available to bring about implementation of the conservation measures considered in this study and the costs and benefits of these measures. A thorough examination in this area is currently under way in the BNI Regional Energy Studies Program, of which the BNL Northeast Energy Perspectives study is a part:

B. Residential and Commercial Energy Consumption: Base Year, 1972.

In 1972 the Northeast United States consumed 5.02 quadrillion, or $10^{15}$, Btu (quad) of energy in the residential and commercial sectors. Of this total, about 66\% (3.30 quads) was consumed in residential households and $34 \%$ ( 1.72 quads) in commercial

- buildings. The detailed end use and fuel distribution by region are shown in Tables 1 and 2 , from which several significant conclusions can be drawn. The combined residential and commercial sector, with $44 \%$ of the total energy use in the Northeast, ${ }^{*}$ is dominant as compared with industrial, transportation, and electric utility energy consumption. By end use; space heating is dominant in both sectors, accounting for about $71 \%$ of the total energy used in the residential sector and $76 \%$ in the commercial sector. In terms of fuel distribution, both sectors are highly dependent on oil, with $54 \%$ of the combined total energy supplied from petroleum products. The data sources and methodologies used to derive these figures are discussed in detail by Lee. ${ }^{2}$

* Total regional energy consumption, including fuel used by electric utilities, was estimated at $14.4 \times 10^{15}$ Btu in 1972 . 
SUMMARY OF RESIDENTIAL AND COMMERCIAL END USE OF ENERGY, $\left(10^{12}\right.$ Btu) $1972^{2}$

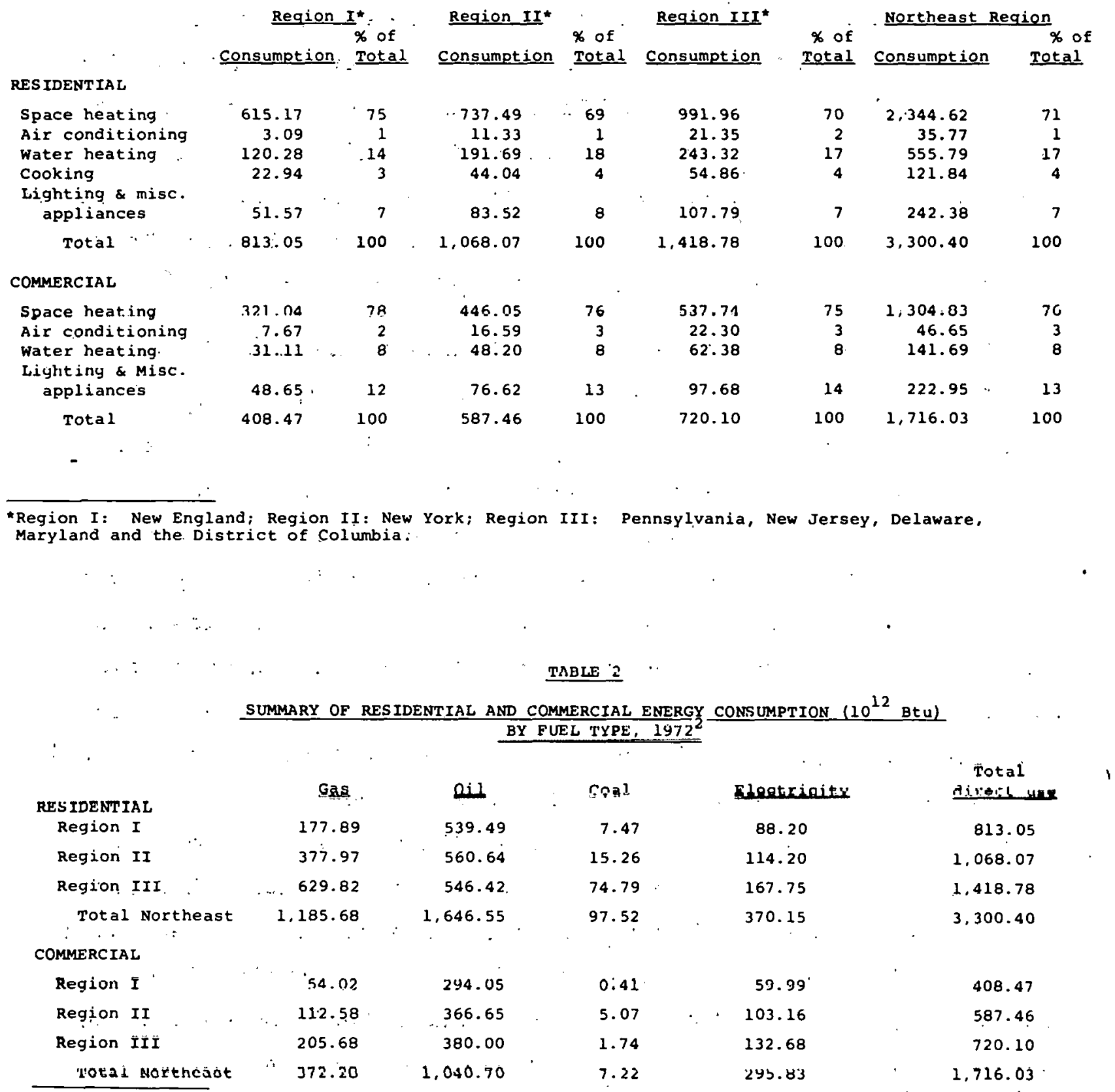

Note: The number of figures obtained do not represent basic precision but are retained tor consistency and calculational purposes. 


\section{1985 and 2000 Energy Demand - Base Case}

The base case projections (like all others) are conditional forecasts, based on an extension of past and present relationships believed to have future relevance for the regional energy use patterns. The assumptions on which these relationships are formulated in the base case reflect a long-run growth situation without major government policy and economic changes. These assumptions (with no probability of realization attached to them) are described in detail in section IV.

The residential and commercial base case demands in the region are projected to grow, respectively, from 3.30 quads and 1.72 quads in 1972 to 3.35 quads and 2.41 quads in 1985 and to reach 3.65 quads and 4.41 quads by the year 2000. These projections do not include losses incurred by the power plants in converting primary fuels to electricity and other distribution losses. The projected demand by end use is detailed in Tables 3 and 4 .

\section{Residential Growth Rate}

Total residential energy use in the region is expected to stay at the 1972 level until 1985 and to increase slowly at an annually compounded growth rate of $0.6 \%$ from 1985 to 2000 . The low rate of growth is due to the slight decline in energy use projected for space heating. Although space heating will continue to be the primary energy user, the average per unit consumption ${ }^{*}$ is expected to decline $21 \%$ by 1985 and $35 \%$ by 2000 . These reductions offset the effect of household growth projected (19.7\% by 1985 and $47.6 \%$ by 2000). The major contributors to this decrease in per unit heating demand are summarized below: *Calculated as the ratio of total direct energy use for space heating to the number of households in the region. Average per unit demand is estimated at $133\left(10^{6}\right.$ Btu/household) in 1972, 105 in 1985, and 86 in 2000. If losses incurred by power plants are included, reduction in per unit energy resource consumption would be $16 \%$ by 1985 and $23 \%$ by 2000 . 
TABLE 3

1985 NORTHEAST RESIDENTIAL AND COMMERCIAL ENERGY DEMAND $\left(10^{12}\right.$ Btu)

BASE CASE

\begin{tabular}{|c|c|c|c|c|c|}
\hline \multicolumn{6}{|l|}{ RESIDENTIAL } \\
\hline Space heating & 690 & 1405 & 108 & 2203 & 66 \\
\hline Air conditioning & - & - & 61 & 61 & 2 \\
\hline Water heating & 286 & 230 & 109 & 625 & 19 \\
\hline $\begin{array}{l}\text { Cooking } \\
\text { Lighting \& misc. }\end{array}$ & 97 & - & 34 & 131 & 4 \\
\hline $\begin{array}{l}\text { Lighting \& misc. } \\
\text { appliances }\end{array}$ & - & - & $\underline{329}$ & $\underline{329}$ & $\underline{19}$ \\
\hline TOTAL & 1173 & 1635 & 641 & 3349 & 100 \\
\hline COMMERCIAL & & & & & \\
\hline Space heating & 255 & 1414 & 74 & 2743 & 72 \\
\hline Air conditioning & 3 & - & 84 & 86 & 4 \\
\hline Water heatiny & 110 & - & 104 & 215 & 9 \\
\hline $\begin{array}{l}\text { Lighting of misc. } \\
\text { appliances }\end{array}$ & - & $=$ & $\underline{366}$ & 366 & 15 \\
\hline TOTAL & 368 & 1414 & 628 & 2410 & 100 \\
\hline
\end{tabular}

TABLE 4

2000 NORTHEAST RESIDENTIAL AND COMMERCIAL ENERGY DEMAND (10 ${ }^{12}$ Btu) DASE CASE

\begin{tabular}{|c|c|c|c|c|c|c|}
\hline \multirow{2}{*}{\multicolumn{7}{|c|}{ RESIDÉNTIAL }} \\
\hline & & & & & & \\
\hline space heating & 597 & 1384 & 248 & & 2229 & 61 \\
\hline Air ronditiening & - & - & 101 & & 101 & 3 \\
\hline Water heating & 279 & 235 & 186 & & 680 & 19 \\
\hline $\begin{array}{l}\text { Cooking } \\
\text { Llaheing \& mise. }\end{array}$ & 90 & - & 51 & & 142 & 4 \\
\hline appliances & $=$ & - & $\underline{482}$ & & 482 & $\underline{13}$ \\
\hline TOTAL & 966 & 1620 & 1067 & & 3654 & 100 \\
\hline COMMERCIAL & & $\therefore$ & & - & & \\
\hline Space heating & 255 & 2664 & 265 & & 3183 & 12 \\
\hline Air conditioning & 3 & - & 177 & & 180 & 4 \\
\hline water heating & 113 & - & 261 & & 373 & 8 \\
\hline $\begin{array}{c}\text { Lighting \& misc. } \\
\text { appliances }\end{array}$ & - & - & 671 & & 671 & $\underline{16}$ \\
\hline TOTAL & 370 & 2664 & 1374 & & 4407 & 100 \\
\hline
\end{tabular}


System efficiency: This includes home design efficiency and mechanical efficiency of the heating devices. Under the base assumptions, the average system efficiency will improve significantly for both existing and new housing units (Appendix A). This improvement reflects the impact of retrofit in existing homes, replacement of old heating devices, better standards for new construction, and improved equipment design.

Fuel mix: The increase in penetration of electric heat from $1 \%$ to $5 \%$ in 1985 and $11 \%$ in 2000 would mean a significant reduction in per unit consumption (at point of entry) because of the greater efficiency of electric systems* (including heat pumps).

Consumer energy ethic: The base case assumes a continuation. of the energy ethic developed during the recent energy shortage (e.g., thermostat setback from $72^{\circ} \mathrm{F}$ to $70^{\circ} \mathrm{F}$ ). This would result. in a saving of $7 \%$ to $10 \%$ in unit consumption over the 1972-2000 period for all households. Since the base case does not assume any major changes in lifestyle or alteration of the consumer's standard of living, the conservation impact is significantly below its full potential.

Housing mix: The present housing stock in the region consists predominantly of single-family homes. Current trends, however, are toward various forms of multifamily housing and mobile homes. This shift toward smaller housing units tends to decrease energy requirements for space heating.

*Inclusion of energy losses at power plants (assuming an average efficiency of $33 \%$ ) would increase the overall annual growth rate. to $0.6 \%$ between 1972 and 1985 and $1.5 \%$ between 1985 and 2000 . However, the inclusion of such losses in a demand analysis. seems inappropriate because it raises the issue of power plant fuel or efficiency, which properly belongs in a supply analysis. 
Despite the low overall growth rate for the projection period, energy use by air conditioning and miscellaneous electric appliances is projected to increase at a fast rate of $2.7 \%$ annually between 1972 and 2000, in Iine with the projected high rates of growth in air-conditioning and appliance saturations.

\section{Commercial Energy Growth}

Energy use in the commercial sector is expected to increase at a much faster pace than in the residential sector with a projected annual growth rate of $2.7 \%$ between 1972 and 1985 and $4.1 \%$ between 1985 and 2000. This is a direct consequence of the implicit assumption in our projection basis that the regional economy will become more service oriented. The projection basis and methodology for this sector are discussed in section III.

From the standpoint of end use, although space heating will continue to be the primary energy use, its relative share in the total is expected to drop somewhat between 1972 and 2000. This is due to the high growth rates of energy use in lighting and appliances and in air conditioning, with annual growth rates of 4.1 and $4.8 \%$ respectively from 1972 to the year 2000. The share of enerqy use by water heating is expected to remain at. the present level of $8 \%$ of the commercial total.

\section{The Potential for Energy Conservation}

The base case projection discussed above quantifies the residential and commercial energy demand by end use and fuel type under the current energy use patterns. In this section, the potential for energy conservation in the residential and commercial sectors is summarized by presenting the energy demands estimated under two different conservation scenarios.

* OBERS projections ${ }^{l}$ show the dominance of commercial activities (services, trade, finance, government, etc.) in the growth of the regional economy over the next 25 years. 
These scenarios assume different implementation levels of the conservation measures included in the base case (see section IV). These levels were developed to reflect different degrees of change in government policy and technology without explicit reference to quantitative response functions for energy demand. An analysis of the response of the energy consumer to policy or economic changes is difficult to perform at the regional level and is not the primary intention of this study.

The growth rates shown in Figure 1 indicate that it is possible, with some technological improvements and slight altering of lifestyle, to reduce energy growth in the combined residential and commercial sectors from an annual rate of $1.72 \%$ to almost zero growth between 1972 and 2000 (0.3\% in the strong conservation case). Note that zero energy growth does not mean zero economic growth. In this study, OBERS projections of economic growth ${ }^{1}$ were used as a basis for all three energy demand scenarios. The $0.3 \%$ growth rate in the strong conservation case implies a reduction in total energy demand of $32 \%$ from that calculated in the base case. The moderate conservation case would reduce the annual growth to $1.1 \%$ and the total energy demand in 2000 by $16 \%$ from the base case projection. It might be noted that, on the average, residential and commercial demand in the U.S. has been following a trend since 1973 that is close to the moderate conservation case. Tables 5 to 8 present the energy demand by fuel type for the three cases in the subregions and the entire Northeast. 


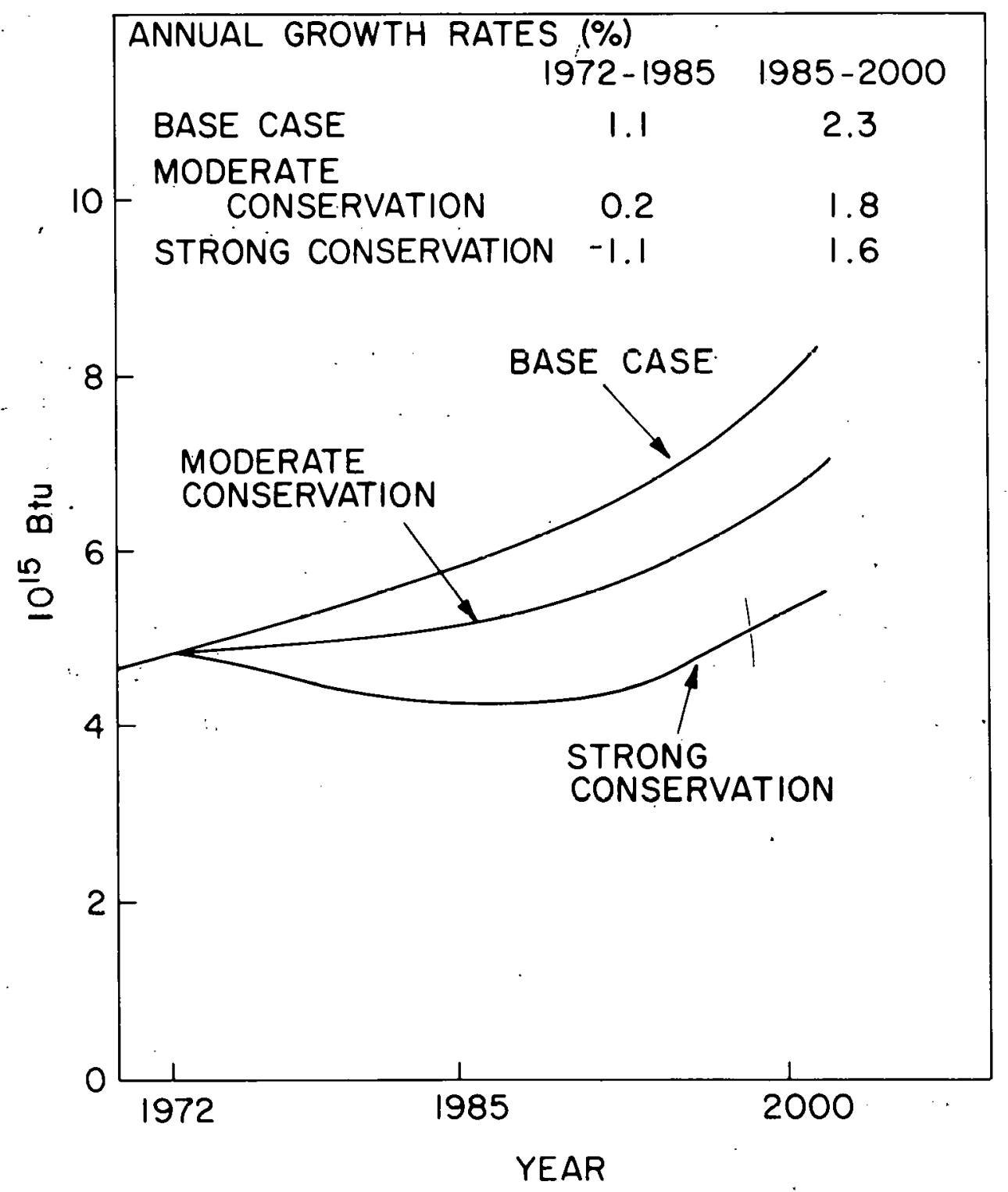

Figure 1. Energy growth in the residential and commercial sector (1972-2000) - base case and conservation scenarios. 
TABLE 5

SUMMARY OF NEW ENGLAND RESIDENTIAL AND COMMERCIAL ENERGY DEMANDS (10 ${ }^{12}$ BtU)

BY FUEL TYPE, 1985 and 2000

\begin{tabular}{lll} 
& \multicolumn{3}{c}{1985} \\
\hline Base & Conservation Cases \\
Case & Moderate & Strong
\end{tabular}

\begin{tabular}{ll}
\hline \multicolumn{2}{c}{2000} \\
Base & Coṇservation Cases \\
Case & Moderate
\end{tabular}

RES IDENT IAL

$\begin{array}{lccccrr}\text { Oil } & 513 & 477 & 363 & 489 & 424 & 297 \\ \text { Gas } & 166 & 156 & 124 & 145 & 132 & 98 \\ \text { Electricity } & 139 & 133 & 120 & 227 & 197 & 158 \\ \text { Solar } & - & - & 6 & - & 37 & 79 \\ \quad \text { TOTAL } & 818 & 766 & 613 & 861 & 790 & 582\end{array}$

COMMERCIAL

$\begin{array}{lcc}\text { Oil } & 421 & 348 \\ \text { Gas } & 50 & 41 \\ \text { Electricity } & 122 & 101 \\ \text { Solar } & - & - \\ \quad \text { TOTAL } & 593 & 490\end{array}$

$348 \quad 302$

302

750

550

419

41

36

51

37

29

88

286

185

141

- -

-

49

80

426

1087

821

669

TABLE 6

SUMMARY OF NEW YORK RESIDENTIAL AND COMMERCIAL ENERGY DEMANDS $\left(10^{12}\right.$ Btu) BY FUEL TYPE, 1985 and 2000

\begin{tabular}{|c|c|c|c|c|c|c|}
\hline \multirow[b]{2}{*}{. } & \multicolumn{3}{|c|}{1985} & \multicolumn{3}{|c|}{$2000^{\circ}$} \\
\hline & $\begin{array}{l}\text { Base } \\
\text { Case }\end{array}$ & $\begin{array}{l}\text { Conservation } \\
\text { Moderate }\end{array}$ & $\begin{array}{l}\text { Cases } \\
\text { strong }\end{array}$ & $\begin{array}{l}\text { Base } \\
\text { Case } \\
\end{array}$ & $\begin{array}{l}\text { Conservation } \\
\text { Moderate }\end{array}$ & $\begin{array}{l}\text { Cases } \\
\text { strong }\end{array}$ \\
\hline $\begin{array}{l}\text { RF.S TDFNTTA T, } \\
\text { Oil }\end{array}$ & 549 & 514 & 399 & 530 & 454 & $319^{\circ}$ \\
\hline Gas & 344 & 311 & 248 & 311 & 266 & $196^{\circ}$ \\
\hline Electricity & 192 & 181 & 162 & 340 & 297 & 243 \\
\hline Solar & - & - & 9 & - & 5.5 & 87 \\
\hline TOTAL & 1085 & 1006 & 818 & 1181 & 1072 & $.845 \ldots$ \\
\hline COMMERCIAL & & & & & & \\
\hline Oil & 477 & 396 & 344 & 860 & 630 & 461 \\
\hline Gas & 99 & 82 & 71 & 109 & 74 & $54^{\circ}$ \\
\hline Electricity & 228 & 189 & 164 & 483 & 354 & 259 \\
\hline Solar & - & - & - & - & 68 & 106 \\
\hline TOTAL & 804 & 667 & 579 & 1452 & 1126 & 880 \\
\hline
\end{tabular}


TABLE 7

SUMMARY OF REGION III RES IDENTIAL AND COMMERCIAL ENERGY. DEMANDS (10 12 Btu) BY FUEL TYPE, 1985 and 2000

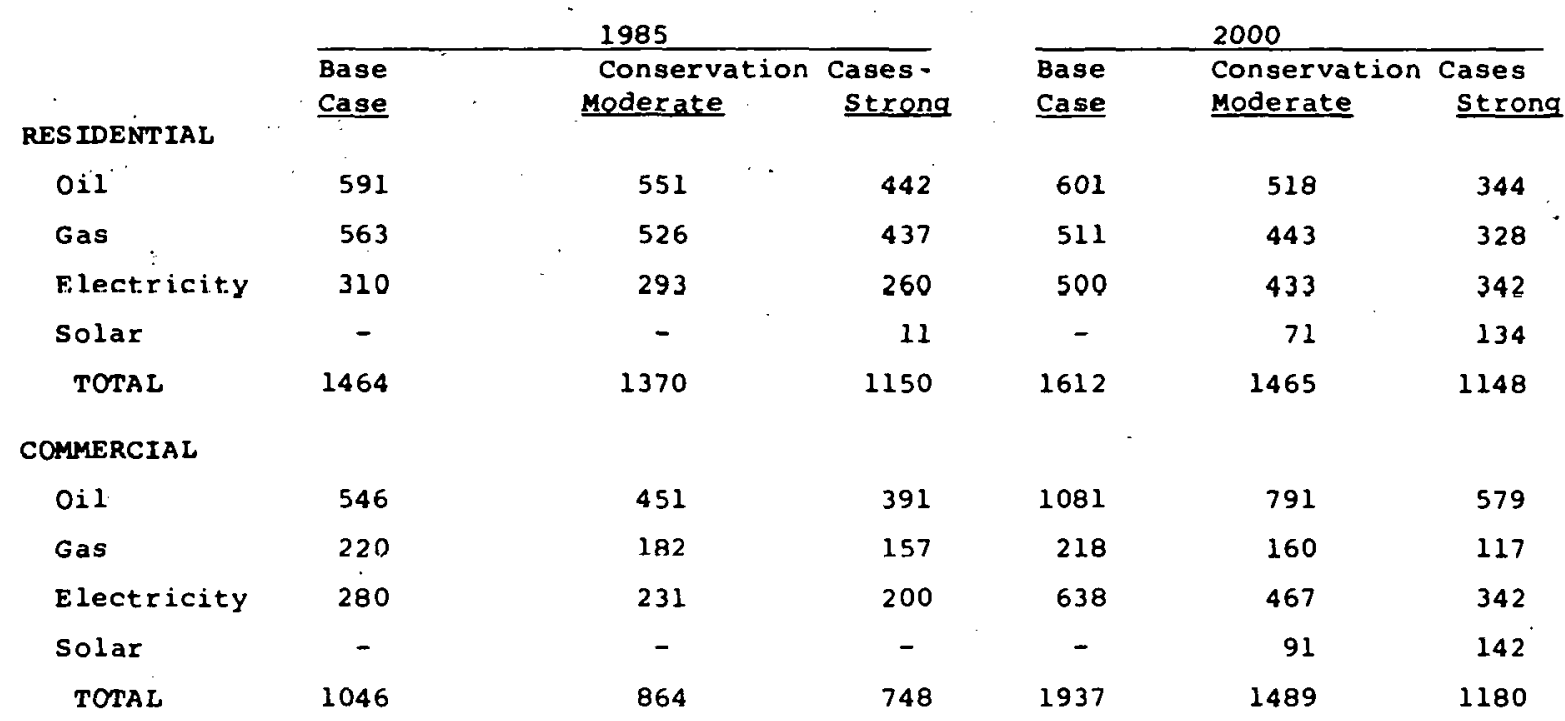

"New Jersey, Pennsylvania, Delaware, Maryland and D.C.

TABLE 8

SUMMARY OF NORTHEAST REGION RES IDENTIAL AND COMMERCIAL ENERGY DEMANDS $\left(10^{12}\right.$ BtU) BY FUEL TYPE, 1985 and 2000

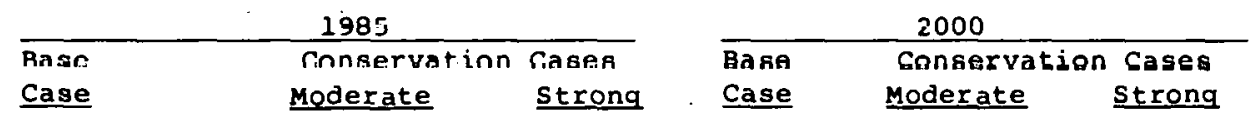

RES IDENT IAL

\begin{tabular}{|c|c|c|c|c|c|c|}
\hline Oil & 1652 & 1542 & 1204 & 1621 & 1396 & 959 \\
\hline Gas & 1073 & 993 & 809 & 967 & 841 & 622 \\
\hline Electricity & 641 & $607^{\circ}$ & 543 & 1067 & 928 & 743 \\
\hline Dolar. & . & - & 36 & - & 363 & 304 \\
\hline TOTAL & 3366 & 3142 & 2581 & 3655 & 3328 & 2628 \\
\hline \multicolumn{7}{|l|}{ OMMERCIAL } \\
\hline Oil & 1443 & 1194 & 1037 & 2691 & 1971 & 1459 \\
\hline Gas. & 368 & 305 & 264 & .370 & 272 & 199 \\
\hline Electricity & 630 & 521 & 452 & 1374 & 1006 & 742 \\
\hline solar & - & - & - & - & 207 & 438 \\
\hline TOTAL & 2441 & 2020 & -1753 & 4435 & 3456 & 2838 \\
\hline
\end{tabular}




\section{RESIDENTIAL ENERGY DEMAND PROJECTIONS}

\section{A. Methodology}

The residential energy demand projections are determined by the prime energy consuming unit, the household. The number of households for the future reference years is derived from two primary factors: population and family size. Their relationship is given by:

$$
\text { Projected households }=\text { projected population } \begin{array}{r}
\text { persons per } \\
\text { household }
\end{array}
$$

Housing type, saturation of utilizing devices, and unit demand by end use are also included in establishing the energy projections. Housing is classified into single-family detached, low-density, low-rise, and high-rise units, and mobile homes. End-usè saturation is categorized by space heating, water heating, air conditioning, cooking, and lighting and miscellaneous appliances. The calculation of annual energy demand involves multiplying the total number of housing units having each end use by the annual unit demand developed in this study. Figure 2 is a schematic representation of the inputs and methodology used in projecting residential energy demand.

B. Residential Inventory and Projections

1. Base-Year (1972) Inventory The housing inventory for 1972 was escalated from that given in the 1970 Census of Housing ${ }^{3}$ by using the average yearly growth rate between 1960 and 1970 given in the 1972 U.S. Statistical Abstract. ${ }^{4}$ These date were then categorized into four housing types*

* The 1970 housing mix was assumed in categorizing the 1972 housing types. A fifth type, the mobile home, is introduced in future years as it becomes more significant in number. 


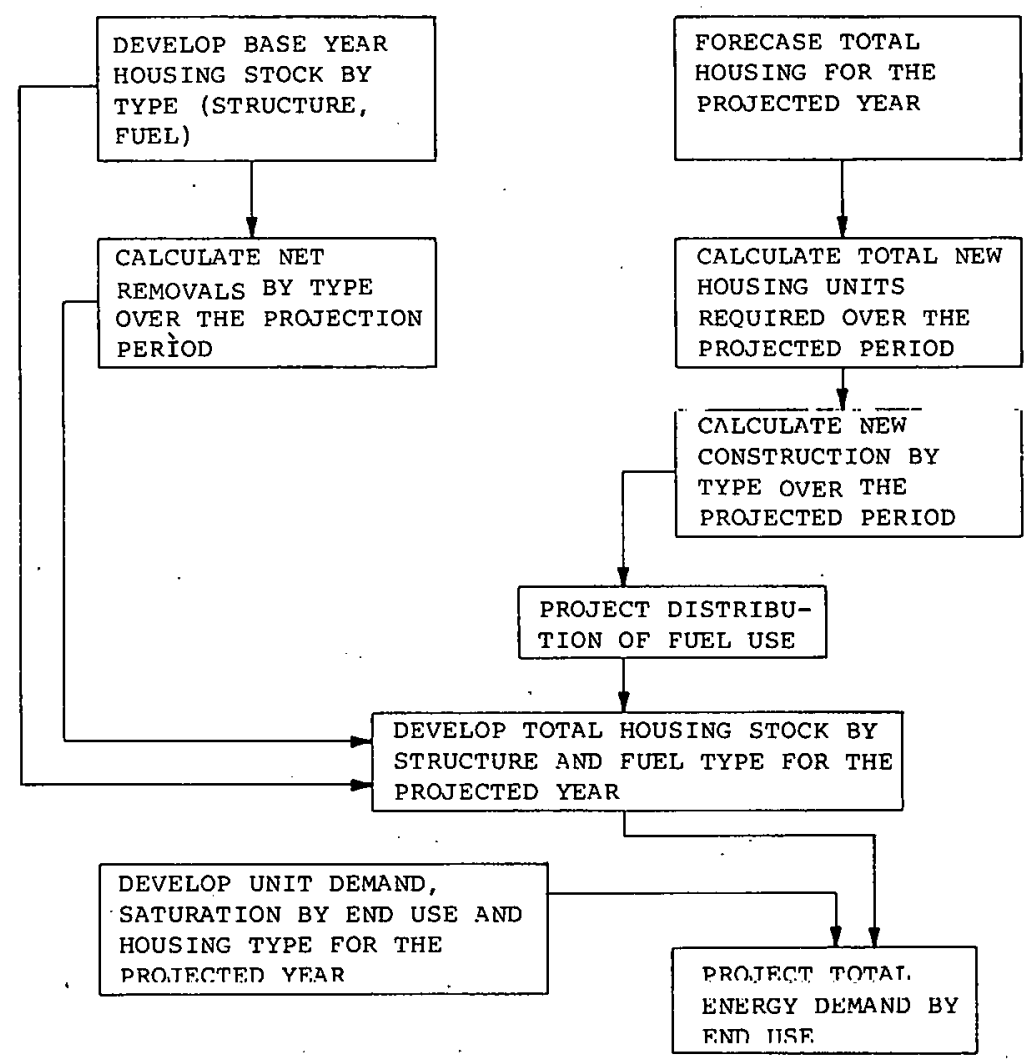

Figure 2. Schematic description of methodology for projecting future residential energy demand. 


\begin{tabular}{|c|c|c|}
\hline Single-family & - & one-unit detached structures \\
\hline Low-density & - & $\begin{array}{l}\text { one-unit attached structures and } 2 \text { to } 4 \\
\text { unit structures }\end{array}$ \\
\hline Low-rise & - & structures with 5 to 19 housing units \\
\hline High-rișe & $\dot{-}$ & structures with 20 or more units \\
\hline
\end{tabular}

Table 9 presents the base-year housing stock by type and fuel mix by end use.

2. Population and Households. As already stated, projections of the total housing stock are based on the projected population and persons per household. They are therefore long-term housing demand projections and are independent of short-term fluctuations of new housing construction rates. The population figures for 1985 and 2000 were taken from the Bureau of the census series $E$ population projection ${ }^{1}$ and are presented in Table 10 .

Estimates of the average number of persons per household for the future reference years were based on the historical trend in the three subregions. The significant decline shown for the future is due to the effects of a long-term reduced birth rate. Table 11 shows projected household size by region and the nation as a whole.

3. 198.5 and 2000 Inventory. The disaggregation of total projected households into housing units by structure type (indicated by subscript $K$ ) is based on

where

$$
\mathrm{HE}_{\mathrm{K}}=\mathrm{HB}_{\mathrm{K}}+\mathrm{C}_{\mathrm{K}}-\mathrm{R}_{\mathrm{K}^{\prime}}
$$

$$
\begin{aligned}
& { }_{\mathrm{HE}}=\text { housing stock at end of projection period, } \\
& { }^{\mathrm{HB}}{ }_{\mathrm{K}}=\text { housing stock at beginning of projection } \\
& \text { period } \\
& \mathrm{C}_{\mathrm{K}}=\text { number of new units constructed during }
\end{aligned}
$$


TABLE 9

SUMMARY OF RESIDENTIAL END USE BY HOUS ING TYPE AND PUEL, $1972^{3}$

$\left(10^{3}\right.$ households)

$\begin{array}{cl}\text { Region } & \begin{array}{l}\text { Housing type } \\ \text { I }\end{array} \\ & \begin{array}{l}\text { Lingle-family } \\ \text { detached } \\ \text { Low density } \\ \text { Low rise } \\ \text { High rise }\end{array} \\ \text { II } & \text { Single-family } \\ \text { detached } & \text { Low density } \\ & \text { Low rise } \\ & \text { High rise } \\ & \text { Single-family } \\ \text { Jelduled } \\ \text { LII } & \text { Low density } \\ & \text { High rife }\end{array}$

\begin{tabular}{rrr} 
& \multicolumn{3}{c}{ Space heat } \\
\hline Gas & 0.1 & Elect \\
& & 8 \\
453 & 1502 & 4 \\
255 & 846 & \\
82 & 273 & \\
33 & 109 & \\
& & \\
875 & 1351 & 41 \\
552 & 853 & 2 \\
299 & 462 & 14 \\
575 & 889 & 27 \\
& & \\
1891 & 1813 & 169 \\
1109 & 1061 & 96 \\
332 & 308 & 3 \\
250 & 240 & 2
\end{tabular}

water heating

cooking

Gas Qil Electricity

Gas Qil Electricit

Air conditioning

Electricity

82
46
15
6

$\begin{array}{rrrr}20 & 658 & 967 & 431 \\ 11 & 371 & 545 & 24 \\ 4 & 120 & 176 & \\ 1 & 48 & 70 & \end{array}$

432
243
79
31

$\begin{array}{rr}843 & 206 \\ 476 & 116 \\ 153 & 37 \\ 61 & 15\end{array}$

1008

$568 \quad 313$

313
101
40

$\begin{array}{rrrrrrrrr}41 & 34 & 990 & 1128 & 184 & 1634 & 184 & 483 & 1013 \\ 26 & 22 & 625 & 712 & 116 & 1032 & 116 & 305 & 640 \\ 14 & 12 & 339 & 386 & 63 & 559 & 63 & 165 & 346 \\ 27 & 23 & 651 & 742 & 121 & 107.5 & 121 & 318 & 666\end{array}$

165
96
38
$2 ?$

$\begin{array}{rrr}247 & 2392 & 990 \\ 145 & 1399 & 579 \\ 13 & 106 & 168 \\ 37 & 31.6 & 131\end{array}$

$\begin{array}{rrr}742 & 2316 & 289 \\ 434 & 1471 & 169 \\ 136 & 127 & 19 \\ 98 & 332 & 38\end{array}$

1320
772
221
1174

TABLE 10

POPULATION BY REGION ${ }^{1}$

(Thousands)

$\begin{array}{cccc}\text { Reqion } & \text { 1972 } & \text { 1985 } & \underline{2000} \\ \text { I } & 12,105.0 & 13,528.3 & 15,226.3 \\ \text { II } & 18,367.0 & 20,132.9 & 22.438 .4 \\ \text { III } & 24,625.0 & 27,791.3 & 31.164 .7 \\ \text { Total Northeast } & 55.097 .0 & 61.452 .5 & 68.829 .4\end{array}$

TABRE 11

NUMRER OF PERSONG PFR HOLSEHOUD

HISTORICAL AND PROJECTED ${ }^{3}$

\begin{tabular}{|c|c|c|c|c|c|c|}
\hline Reqion & 1950 & 1960 & 1970 & 1972 & 1985 & 2000 \\
\hline I & 3.56 & 3.37 & 3.25 & 3.23 & $3.03^{\mathrm{a}}$ & $2.80^{a}$ \\
\hline II & 3.42 & 3.20 & $3.0 y$ & 3.013 & $2.80^{7}$ & 2. $b U^{\nexists}$ \\
\hline III & 3.53 & 3.39 & 3.35 & 3.17 & $2.96^{\mathrm{a}}$ & $2.70^{\mathrm{a}}$ \\
\hline U.S. & 3.37 & 3.33 & 3.14 & 3.06 & $2.95^{b}$ & $2.68^{b}$ \\
\hline
\end{tabular}

Based on the average reduction rate between 1950 and 1970 .

${ }^{b}$ Ford Poundation projection.' 


$$
\begin{aligned}
\mathrm{R}_{\mathrm{K}}= & \text { net removals from housing stock during projection } \\
& \text { period. }
\end{aligned}
$$

The net removal rates were taken from a Project Independence Task Force Report. ${ }^{6}$ These rates have been developed by A.D. Little, Inc., from the Northeast regional data on housing inventory change from 1950 to 1960 and 1960 to 1970. The net removal rates have been examined with respect to the implied life of each type of structure and the general age characteristics of the region's housing inventory. These rates were applied to the base-year. housing stock to generate the net removals by structure type for the region.

The aggregate new construction in the region over the projection period was obtained by subtracting the base-year inventory (less removals) from the total projected households at the end of the period. Total new construction was distributed among structure types on the basis of the distribution of new units projected in ref. 6. The distribution implies that the construction trend is shifting from single-family structures to various forms of multifamily housing and increasing numbers of mobile homes. The nèw units by structure type $\left(\mathrm{C}_{K}\right)$, plus the base-year inventory $\left(\mathrm{HB}_{\mathrm{K}}\right)$, less the removals $\left(R_{K}\right)$, equal the projected inventory $\left(H_{K}\right)$. Table 12 presents the housing inventory by type and region based on these calculations.

\section{c. Unit Eemand and Saturation by End Use}

In general, unit demands are a function of building type, location, fuel type, and end-use efficiency. For space heating, unit demands for existịng housing units (buildings existing,in 1972) were derived from the average unit demands in ref. 6 based.. on values of heating degree day and average house size. Unit. demands for new housing units were derived in a BNL report.. 7 Unit demands for water heating, air conditioning, and lighting and 
TABLE 12

\begin{tabular}{|c|c|c|c|c|c|c|c|}
\hline & $\begin{array}{c}1972 \\
\text { Inventory } \\
\end{array}$ & $\begin{array}{c}\text { New } \\
\text { construction } \\
(\underline{1972-85)}\end{array}$ & $\begin{array}{r}\text { Removals } \\
(1972-85) \\
\end{array}$ & $\begin{array}{c}1975 \\
\text { Inventory }\end{array}$ & $\begin{array}{c}\text { New } \\
\text { construction } \\
(1975-2000)\end{array}$ & $\begin{array}{c}\text { Removals } \\
(1975-2000)\end{array}$ & $\begin{array}{c}2000 \\
\text { Inventory }\end{array}$ \\
\hline REGION I & 3.740 & 1,440 & 715. & 4.465 & 1,952 & 979 & 5,438 \\
\hline Single-fanily & 2,023 & 670 & 221 & 2,472 & 1.040 & 316 & 3,196 \\
\hline Low-density & 1.140 & 344 & 326 & 1.158 & 420 & 382 & 1.196 \\
\hline Low-rise & 368 & 192 & 91 & 469 & 232 & 126 & 575 \\
\hline High-rise & 148 & 46 & 37 & 157 & 60 & 42 & 175 \\
\hline Mobile home & 61 & 188 & 40 & 209 & 200 & 113 & 216 \\
\hline REGION II & 6,057 & 2,385 & 1,252 & 7,190 & 3,510 & 1.725 & 8,975 \\
\hline Single-family & 2.272 & 753 & 248 & 2.777 & 1,318 & 350 & 3,745 \\
\hline Low-density & 1,434 & 432 & 392 & 1.474 & 716 & 486 & 1,704 \\
\hline Low-rige & 777 & 406 & 192 & 991 & 532 & 267 & 1,256 \\
\hline High-rise & 1.497 & 463 & 370 & 1.590 & 573 & 429 & 1,734 \\
\hline Mobile home & 77 & 331 & 50 & 358 & 371 & 193 & 536 \\
\hline REGION III & 7.781 & 2,922 & 1.314 & 9.389 & 3.976 & 1.823 & 11,542 \\
\hline Single-family & 4,053 & 1,343 & 443 & 4,953 & 2,140 & 624 & 6,469 \\
\hline Low-density & 2,371 & 715 & 483 & 2,603 & 830 & 601 & 2,832 \\
\hline Low-rise & 688 & 360 & 169 & 879 & 436 & 237 & 1.078 \\
\hline High-rise & 537 & 166 & 133 & 570 & 210 & 154 & 626 \\
\hline Mobile home & 132 & 338 & 86 & 384 & .360 & 207 & 537 \\
\hline NORTHEAST REGION & 17., 578, & 6,747 & 3,281 & 21,044 & 9.438 & 4,527 & 25.955 \\
\hline Single-family & 8,348 & 2,766 & 912 & 10,238 & 4.498 & 1,290 & 13,446 \\
\hline Low-density & 4,945 & 1,491 & 1,201 & 5.235 & 1,966 & 1.469 & 5,732 \\
\hline Low-rise & 1,033 & 958 & 452 & 2,339 & 1,200 & 630 & 2,909 \\
\hline High-rise & 2,182 & 675 & 540 & 2,317 & 843 & 625 & 2,535 \\
\hline Mobile home & 270 & 857 & 176 & 951 & 931 & 513 & 1,369 \\
\hline
\end{tabular}

miscellaneous appliances were obtained from refs. 2 and 6 . Table 13 shows the average annual unit demand by end use and fuel type for the existing housing units. Unit demands for retrofitted homes and new construction can be found in Appendix A.

Saturation rates for space heating, water heating, and cooking were assumed to be unity for all reference years. The saturation is defined as the fraction of the potential demand for a particular energy use that is actually being fulfilled at a given time. For example, if $95 \%$ of all households have refrigerators and the potential demand for refrigerators is taken to be one per house, the saturation is 0.95. For air conditioning and miscellaneous electric appliances, saturation rates were derived from a census of housing ${ }^{8}$ and saturation growth rates given in ref. 6. For most appliances, the saturation is cxpcctcd to incrcacc oignificantly. However, unit demand for some of these appliances is projected to decrease somewhat because of design improvements. Table 14 summarizes the saturation rates and unit demands for lighting and miscellaneous appliances. 
TABLE 13

ANNUAL UNIT DEMAND $\left(10^{6}\right.$ Btu) PÓR RESIDENTIAL END USES, EXCEPT

LIGHTING AND MISCELLANEOUS APPLIANCES, 1972

End Use $\frac{\text { Housing type }}{\text { space heating Single-family }}$ detached Low density Low rise High rise

water heating single-family detached Low density Low rise High rise

Electricity

Reqion I Reqion II Reqion III Reqion I Reqion II Reqion III Reqion I Reqion II. Reqion III

\begin{tabular}{|c|c|c|c|c|c|c|c|c|}
\hline 176 & 150 & 143 & 209 & 182 & 170 & 83 & 71 & 68 \\
\hline 124 & 106 & 101 & 148 & 126 & 120 & 59 & 50 & 48 \\
\hline 84 & 72 & 68 & 100 & 85 & 81 & 40 & 34 & 32 \\
\hline 78 & 67 & 63 & 93 & 80 & 75 & 37 & 31 & 30 \\
\hline 43 & 43 & 43 & 39 & 39 & 39 & 25 & 25 & 25 \\
\hline 32 & 32 & 32 & 29 & 29 & 29 & 18 & 18 & 18 \\
\hline 27 & 27 & 27 & 25 & 25 & 25 & 16 & 16 & 16 \\
\hline 27 & 27 & 27 & 25 & 25 & 25 & 16 & 16 & 16 \\
\hline
\end{tabular}

cooking single-family detached Low density

Low rise

$\begin{array}{lllll}9.6 & 9.6 & 9.6 & 9.6 & 9.6 \\ 8.2 & 8.2 & 8.2 & 8.2 & 8.2 \\ 7.2 & 7.2 & 7.2 & 7.2 & 7.2\end{array}$

Air conditioning

Room

7.2

7.2

9.6
8.2
7.2
7.2

9.6
8.2
7.2
7.2

3.7

3.7

$3.1 \quad 3.1$

$\begin{array}{lll}2.8 & 2.8 & 2.8 \\ 2.8 & 2.8 & 2.8\end{array}$

tioning Rontral

TABLE 14

\begin{tabular}{|c|c|c|c|c|c|c|}
\hline \multirow[b]{3}{*}{ End-Use Device } & \multicolumn{6}{|c|}{ AND MISCELLANEOUS ELECTRIC APPLIANCES $2,6,8$} \\
\hline & \multicolumn{3}{|c|}{ Saturation } & \multicolumn{3}{|c|}{ Unit Demand $\left(10^{6}\right.$ Btu $)$} \\
\hline & 1972. & $\underline{1985}$ & 2000 & 1972 & $\underline{1985}$ & $\underline{2000}$ \\
\hline Lighting & 1.00 & 1.00 & 1.00 & 3.10 & 3.10 & 3.10 \\
\hline Dishwasher & 0.24 & 0.70 & 0.90 & 1.30 & 1.15 & 1.15 \\
\hline Washing machine & 0.85 & 0.90 & 0.95 & 0.35 & 0.35 & 0.35 \\
\hline Dryer & 0.33 & 0.50 & 0.70 & 3.40 & 3.40 & 3.40 \\
\hline Color TV & 0.43 & 0.90 & 1.00 & 2.10 & 1.50 & 1.50 \\
\hline BEW TV & 0.82 & 0.80 & 0.70 & 1.20 & 0.40 & 0.40 \\
\hline Freezer & 0.22 & 0.35 & 0.50 & 4.80 & 4.50 & 4.20 \\
\hline Refrigerator & 1.00 & 1.10 & 1.25 . & 4.50 & 4.50 & 4.50 \\
\hline $\begin{array}{l}\text { Misc. small } \\
\text { oppliancoo }\end{array}$ & 0.60 & 0.30 & 0. A. & 2.50 & 2.50 & 2,50 \\
\hline Average & 0.60 & 0.73 & 0.88 & & & \\
\hline
\end{tabular}


THIS PAGE

\section{WAS INTENTIONALLY}

LEFT BLANK 


\section{A. Methodology}

The commercial sector as defined in this study is an agglomeration of diverse activities including wholesale and retail trade, finance and insurance, services, schools, hospitals, cultural and recreational establishments, and government institutions. The basic approach used to project the disaggregated energy demand for future reference years' is similar to that used in the residential area. First, the floor-space inventories associated with the commercial activities listed above are forecast by building type. The building categories include offices, retail establishments, schools, hospitals, and miscellaneous buildings.* Then the end-use demand per unit area is developed by building type. The disaggregated energy demands are the product of these two factors. Figure 3 is a schematic representation of the methodology used.

\section{B. Commercial Inventory Projections}

1. Base-Year Inventory. Since few historical and current regional data have been published on commercial floor space, the 1972 commercial inventory was developed by regionalizing a national inventory developed in ref. 6. The office building inventory was regionalized by using total number of employees in services, finance, insurance, real estate, and government. Regional distribution of retail inventory was based on employment in wholesale and retail trade. School inventory was distributed according to

\footnotetext{
* Miscellaneous buildings include passenger and freight terminal buildings, religious buildings, social and recreational buildings, etc.
} 


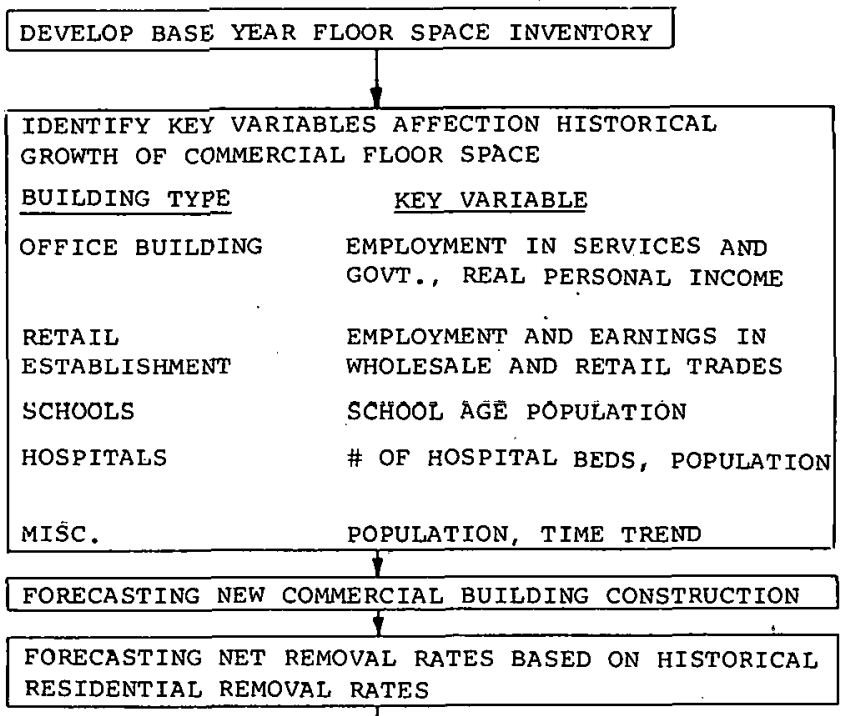

DEVELOP UNIT ENERGY DEMAND BY BUILDING TYPE FOR VARIOUS USES 1

ESTIMATE FUTURE FUEL MIX FOR END USES 1

CALCULATE ENERGY DEMAND BY BUILDING TYPE FOR FND USES

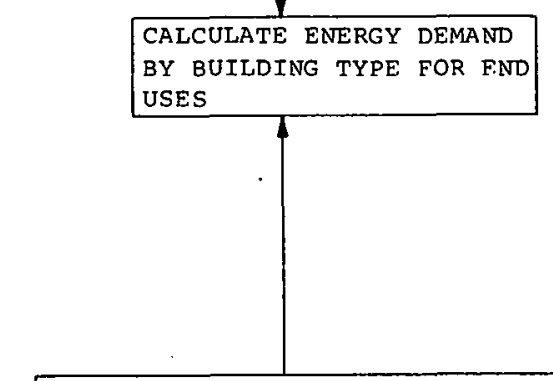

CALCULATE TOTAL FLOOR SPACE BY BUILDING TYRE FOR THE FROJECTED YEAR

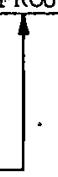

Figure 3. Schematic description of methodology for projecting future commercial energy demand. 
school-age population, hospitals by number of hospital beds, and miscellaneous buildings by total population in the region:

2. Commercial filoor space Projections. Accurate projections of commercial floor space on the regional level are difficult to make since there is little information on future commercial building construction. The method used here to forecast commercial inventory involves four basic steps: (1) Forecast new construction by building type on the national level for the periods 1972-1985 and 1985-2000, (2) regionalize new construction estimated in (1), (3) forecast regional removal rates for the same period, and (4) calculate the total inventory by building type for the future reference years.

In the absence of a regional model, national estimates of commercial floor space were derived on the basis of the regression analysis presented in ref. 6. The net addition of commercial floorspace in one year over a previous year's inventory is

where

$$
\mathrm{N}_{n+1}=\mathrm{Y}_{\mathrm{n}+1}-\mathrm{S}_{\mathrm{n} \mathrm{R}^{\prime}}
$$

$$
\mathrm{Y}_{\mathrm{n}+1}=\text { new construction in year } \mathrm{n}+1 ; \mathrm{s}_{\mathrm{n}}=\text { total }
$$

inventory in year $n$, and $R_{n}=$ demolition rate in year $n$. The inventory in year $n+1$ is $s_{n+1}=s_{n}+N_{n+1}$. substituting, we have

or

$$
s_{n+1}=s_{n}+Y_{n+1}-s_{n} R_{n}=Y_{n+1}+\left(1-R_{n}\right) s_{n}
$$

$$
\begin{aligned}
S_{n+1}= & Y_{n+1}+\left(1-R_{n}\right) Y_{n}+\left(1-R_{n}\right)^{2} Y_{n-1}+\cdots \\
& \left(1-R_{1}\right)^{n_{1}} Y_{1}+s_{0}\left(1-R_{0}\right)^{n+1},
\end{aligned}
$$

where $s_{0}$ is the base-year inventory. 
In projecting new construction in the years 1985 and 2000 , real personal income values and population from the OBERS projection $^{l}$ were used. Yearly new construction between 1972 and future reference years was derived by assuming linear growth in new construction between projection periods. The cumulative total of new floor space by building type is summarized in Table 15 .

As with the base-year inventory, new construction was regionalized by apportioning the total according to regional personal income forecasts, earnings in wholesale and retail trade from OBERS projections, 1 and the Bureau of the census series $E$ population projection. ${ }^{1}$

TABLE 15

NEW COMMERCIAL FLOORSPACE CONSTRUCTION $\left(10^{6} \mathrm{CL}^{2}\right)$ in the U.G.

Building type
Office
Retail
School
Hospital
Miscellaneous

$1972-1985$
3,984
5,740
3,234
1,132
4,445

$\underline{1985-2000}$

8,740

13,205

4,404

1,691

0,687

Forecasting removals from the cumuerial inventory is difficult because of the lack of data on current and historical removal rates and the age distribution of the buildings. In this report, we have used the regional removal rates estimated in ref. 6, which were assumed to be the salle as regidential removal rates in the region for the 1960-1970 period.

Thr base-year inventory and the results of the forecast are summarized in Table 16. 
TABLE 16

\begin{tabular}{|c|c|c|c|c|c|c|c|c|}
\hline \multirow[b]{2}{*}{ Region } & \multirow[b]{2}{*}{ Building type } & \multicolumn{6}{|c|}{$\frac{\text { COMMERCIAL FLOOR-\$PACE INVENTORY }}{\left(10^{6} \frac{\mathrm{ft}}{2}\right)}$} & \multirow[b]{2}{*}{$\underline{2000}$} \\
\hline & & 1972 & $\begin{array}{c}\text { New } \\
\text { Construction } \\
\underline{1972-85}\end{array}$ & $\begin{array}{l}\text { Removals } \\
1972-85 \\
\end{array}$ & 1985 & $\begin{array}{c}\text { New } \\
\text { Construction } \\
1985-2000 \\
\end{array}$ & $\begin{array}{l}\text { Removals } \\
1985-2000 \\
\end{array}$ & \\
\hline I & Office & 234 & 247 & 26 & 455 & 538 & 31 & 962 \\
\hline . & Retail & 274 & 336 & 30 & 580 & 772 & 35 & 1317 \\
\hline & School & 287 & 179 & 32 & 434 & 144 & 36 & 542 \\
\hline & Hospital & 118 & 65 & 13 & 170 & 97 & 15 & 252 \\
\hline & Miscellaneous & 465 & 256 & 52 & 669 & 501 & 59 & 1111 \\
\hline II & Office & 416 & 441 & 46 & 781 & 868 & 53 & 1596 \\
\hline & Retail & 440 & 485 & 47 & 878 & 1287 & 57 . & 2108 \\
\hline & School & 447 & 241 & 49 & 639 & 331 & 58 & 912 \\
\hline & Hospital & 197 & 97 & 22. & 272 & 144 & 25 & 391 \\
\hline . & Miscellaneous & 705 & 381 & 78 & 1008 & 739 & 90 & 1657 \\
\hline III & Office & 484 & 502 & 54 & 932 & 1091 & 61 & 1962 \\
\hline & Retail & 579 & 717 & 64 & 1232 & 1608 & 69 & 2771 \\
\hline & School & 624 & 401 & 69 & 956 & 498 & 80 & 1374 \\
\hline & Hospital & 222 & 134 & 25 & 331 & 200 & 28 & 503 \\
\hline & Miscellaneous & 945 & 527 & 104 & 1368 & 1026 & 121 & 2273 \\
\hline Northeast & $\begin{array}{l}\text { Office } \\
\text { Retail } \\
\text { School } \\
\text { Hospital } \\
\text { Miscellaneous }\end{array}$ & $\begin{array}{r}1134 \\
1293 \\
1358 \\
537 \\
2115\end{array}$ & $\begin{array}{r}1160 \\
1538 \\
821 \\
296 \\
1164\end{array}$ & $\begin{array}{r}126 \\
141 \\
150 \\
60 \\
234\end{array}$ & $\begin{array}{r}2168 \\
2690 \\
2029 \\
773 \\
3045\end{array}$ & $\begin{array}{r}2497 \\
3667 \\
973 \\
441 \\
2266\end{array}$ & $\begin{array}{l}145 \\
161 \\
174 \\
68 \\
270\end{array}$ & $\begin{array}{l}4520 \\
6196 \\
2828 \\
1146 \\
5041\end{array}$ \\
\hline
\end{tabular}

C. Unit Demand by End Use

The unit demands (Btu/ft ${ }^{2}$ ) in this sector were originally derived in ref. $6^{\circ}$ for the Northeast and were based on specific assumptions about the building design and energy system characteristics. * They are probably best regarded as prototypical., not average, values. Projections based on these unit demands are far less certain than those in the residential sector because of the wide variance in energy consumption per square foot between similar buildings with comparable utilizing devices. However, in establishing the 1972 commercial energy consumption in the region, these unit demands have produced results that are in excellent agreement with other independently reported data. ${ }^{2}$ This has led to the conclusion that they are representative of the construction and design standard within each region. Table 17 shows the unit demands by end use for 1972 commercial buildings. In forecasting the future energy demand, some of these figures have been reduced to reflect conservation impacts. These reductions, while significant, imply no major changes in technology or Iifestyle. Detailed discussions of these points are presented in sertion IV. 
TABLE 17

1972 COMMERCIAL UNIT DEMAND $\left(10^{6}\right.$ Btu $)$ BY END USE, NORTHEAST REGION ${ }^{2}$

\begin{tabular}{|c|c|c|c|c|c|c|c|c|}
\hline \multirow{2}{*}{$\begin{array}{l}\text { Reqion } \\
\text { Reques }\end{array}$} & \multirow[b]{2}{*}{ Building type } & \multicolumn{3}{|c|}{ Space heating } & \multirow[b]{2}{*}{ Coal } & \multicolumn{2}{|c|}{ Air conditioning } & \multirow{2}{*}{$\frac{\text { Miscellaneous Appliances }}{\text { Electricity }}$} \\
\hline & & Gas & Qil & Electricity & & Electricity & Gas & \\
\hline \multirow{4}{*}{ I } & office & 310 & 313 & 165 & 345 & 0 & 160 & 6 \\
\hline & Retail & 172 & 174 & 92 & 191 & 10.8 & 17.9 & $\begin{array}{l}31.6 \\
34.0\end{array}$ \\
\hline & School & 275 & 278 & 146 & 306 & 8.5 & 14.1 & 27.2 \\
\hline & Hospital & 333 & 336 & 176 & 370 & 12.0 & 20.0 & 71.3 \\
\hline & Other & 172 & 174 & 92 & 191 & 10.8 & 17.9 & 31.6 \\
\hline \multirow[t]{5}{*}{ II } & Office & 267 & 270 & 142 & 297 & 12.2 & 20.3 & 31.6 \\
\hline & Retail & 148 & 150 & 79 & 165 & 13.6 & 22.7 & 34.0 \\
\hline & School & 237 & 240 & 126 & 264 & 10.7 & 17.9 & 27.2 \\
\hline & Hospital & 287 & 290 & 152 & 319 & 15.2 & 25.4 & 71.3 \\
\hline & Other & 148 & 150 & 79 & 165 & 13.6 & 22.7 & 31.6 \\
\hline \multirow[t]{5}{*}{ III } & Office & 249 & 252 & 133 & 277 & 13.7 & 22.8 & 31.6 \\
\hline & Retail & $138^{\circ}$ & 140 & 74 & 154 & 15.3 & 25.5 & 34.0 \\
\hline & School & 221 & 224 & 118 & 247 & 12.0 & 20.1 & 27.2 \\
\hline & Hospital & 268 & 271 & 142 & 298 & 17.1 & 28.6 & 71.3 \\
\hline & Other & 138 & 140 & 74 & 154 & 15.3 & 25.5 & 31.6 \\
\hline
\end{tabular}

The values of unit demands were adjusted for the three Northeast subregions on the basis of the average annual heating degree days in each area. Population-weighted annual heating degree days were estimated at 6320 for Region I, 5480 for Region II, and 5090 for Region III.

$\checkmark$ 
Section I demonstrated the significance of conservation measures in reducing the region's energy demand in the residential and commercial sectors. The purpose of this section is to evaluate the conservation measures included in this study ${ }^{9}$ and to provide a detailed description of the three levels of implementation of each measure on which the three scenarios--the base case, the moderate conservation case, and the strong conservation case--were constructed.

\section{A. Conservation and Demand Projection}

1. Base Case. The energy demands for the base case were calculated under the assumption of no major technological, price, or government policy changes. Some conservation measures were included because current market forces alone are expected to bring about their implementation, although certain market imperfections are assumed to remain. This means that gradual improvements in efficiency can be expected for most elements of the energy system in new construction and some reduction in unit energy demand for existing structures. It is assumed that some existing structures will be retrofitted with better insulation and that their heating units will receive better maintenance. All buildings are assumed to be operated in a less energy intensive fashion; e.g., residences will have their thermostats set back from $72^{\circ} \mathrm{F}$ to $70^{\circ} \mathrm{F}$ for heating. The fuel mix for the residential sector was estimated on the basis of the fuel mix in existing housing units and the following assumptions about new housing units:

(a). The number of new gas-heated homes will equal the number nf remnvals from the existing gas-heated hnusing stock.

(b) Thirty percent of the new structures built between 1972 and 1985 will be electrically heated, and 50\% thereafter. 
(c) The remaining new housing units will be heated by oil.

For the commercial sector, the amount of natural gas used and the relative market share of oil were kept constant at the 1972 levels, the remaining demand being met by electricity. The use of other fuels and solar energy was assumed to be negligible.

2. Moderate Conservation Case. The energy demands for this case were projected under the assumption of a higher implementation level of the conservation measures considered in the base case. It is assumed that government policies to improve the operation of the market system will be implemented. In this case, the public is not generally asked to sacrifice convenience or to change lifestyle.

All the measures are assumed to be in the economic selfinterest of the consumer. The fuel mix is altered from that in the base case by the assumption that $25 \%$ of the structures built between 1985 and 2000 will receive $50 \%$ of their space heat demand from solar devices. For water heating, solar energy is assumed to supply $35 \%$ of the demand for these structures. The amount of solar energy used reduces the total demand for oil, gas, and electricity, compared with base case requirements.

3. Strong Conservation Case. For this case, it is assumed that government policies strongly affect conservation measures through direct requlation and alteration of prices. Some public sacrifice: of convenience and changes in lifestyle are expected. In the residential sector, all new fossil-fuel heated homes are assumed to be built in accordance with ASHRAE-90 standards. It is assumed that 40\% of the new electric homes built between 1972 and 1985 will use heat pumps, and $100 \%$ thereafter. Retrofits of existing homes are implemented at $5 \% / y r$. to 1985 , compared with $2 \%$ in the moderate conservation case and $1 \%$ in the base case. 
Existing commercial buildings are expected to reduce their unit energy demands by 25 to $35 \%$ through advances in technology and changes in operating procedures. For new commercial buildings, reductions are expected to reach $50 \%$.

Table 18 summarizes the levels of implementation and the estimated impacts of each measure under the three scenarios.

B. Measures for Reducing Energy Consumption

The assessments and justifications behind some of the conservation measures in Table 18 that have significant impact on regional energy use are discussed below.

Conservation measure: Improved insulation of existing homes through retrofits of insulation, storm windows, and storm doors. and through recaulking.

Backqround: The Federal Power Commission ${ }^{10}$ estimates that the addition of ceiling insulation to an existing family home can reduce the annual energy requirements for space heating by 10 to $37 \%$. The specific savings realized in any particular home would depend on the amount of insulation already installed--the better the original insulation, the less effective the additional ceiling insulation. The FPC estimates that further savings, up to another $20 \%$, could be realized by weather-stripping, recaulking, and the addition of storm windows and doors where these do not already exist.

BNL calculations ${ }^{7}$ indicate that an average saving of $30 \%$ per unit could be achieved in single family homes in the Northeast by retrofitting insulation, storm windows, and storm doors and by recaulking. To be conservative, half this amount (15\%) is assumed as the average saving per unit, on the premise that not everyone will perform complete retrofits (some will perform only 
TABLE 18

SUMMARY OF CONSERVATION SCENARIOS

\section{CONSERVATION MEASURES \\ RESIDENXIAL - Space Heating \\ Improved insulation in existing homes - retrofits of insulation, storm windows. family homes. \\ 2. Improved insulation in new homes - adoption of energy conservation building codes. \\ 3. Improved maintonanoo of oxicting oil and gas furnaces. \\ 4. Improved design of new gas and oil heating systems. \\ 5. Use of electric heat pumps instead of resistance heating.}

6. Solar space heating in new homes

7. Lowered thermostats

Aix_conditioning

1. Improved insulation

2. Improvod efficioncy - now air condilioner's

3. Higher thermoetet lovels

- Water Heating

1. Improved efficiency and ingulation of of now water heatore.

2. Use'of solar energy for water heating

- coukline

1. Improved efficiency of ovens - microwave

- Liahting and Miscellaneous Electric

1. Improved efficiency - fluoregcent lights, Inperave

COMMRCIpI - Space Heating, cooling and Lighting

1. Reduced demand in exlating bulldings lowered thermootato, improved oposst in lowered thermostato, improved oposst
procedures, reduced lighting levelo.

2. Improved efficiencies in new buildinga air conditioning, total energy systems, liqhting levels, etc.

3. Space heating and water heating from colar onerty.

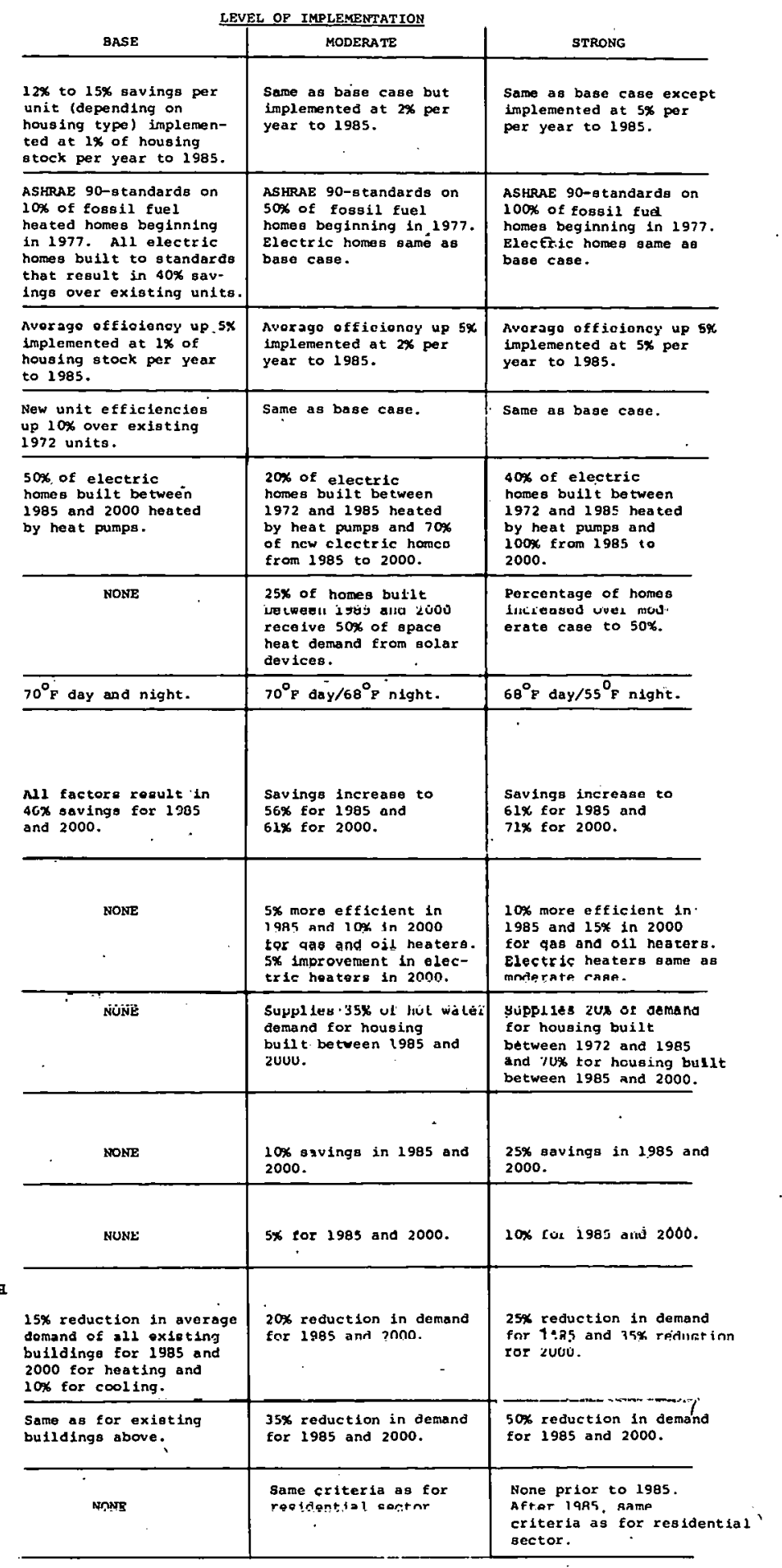


partial retrofits, neglect to recaulk, etc.) and that imperfect workmanship will deny the homeowner some of the savings that are theoretically possible.

Smaller savings are available in high-rise residential buildings through retrofits of insulation because of their lower surface-tovolume ratios compared with single-family dwellings. For these structures, it is assumed that retrofits of insulation will reduce fuel consumption for space heating by an average of $12 \%$.

Scenarios: 1. Base Case. 1\% of the existing residential structures are retrofitted per year through 1985: No further retrofits are performed thereafter. Average savings per unit (i.e., decreases in unit energy demand) are 15\% for single-family homes and $12 \%$ for high-rise apartment buildings:

2. Moderate Case. $2 \%$ of the existing residential structures are retrofitted per year through 1985 .

3. Strong Case. $5 \%$ of the existing residential structures are retrofitted per year. All houses not demolished are eventually retrofitted.

Conservation measure: Improved insulation in new homes-adoption of energy-conserving building codes.

Background: The Board of Directors of ASHRAE recently (Aug. 11, 1975) appioved Llie Iung-delualed AsHRAE 90-P (now 90-75) standards for construction. 11 These are model building codes designed to save energy used in home heating. ASHRAE estimates that these standards will "save at least 10-20\% of the energy now used in residential structures and possibly twice as much in industrial, commercial, governmental, and institutional buildings."ll 
Scenarios: 1. Base Case. Beginning in 1977, 10\% of all new homes are constructed in accordance with ASHRAE 90-75. An average reduction in unit demand of 15\% compared with the 1972 level is achieved.

2. Moderate Case. $50 \%$ of all new homes are constructed in accordance with ASHRAE 90-75 starting in 1977. This level of implementation will depend on adoption of the code by FHA and some state and local governments in the Northeast (Berg $^{12}$ has estimated that FHA standards have a direct effect on $\sim 35 \%$ of now construction).

3. Strong Case. All new homes are constructed in accordance with ASHRAE 90-75 starting in 1977. This level of implementation will probably depend on national adoption of the cuale.

Conservation measure: Improved maintenance of existing oil and gas furnaces.

Background: A limited Field study ${ }^{13}$ indicates that the average efficiency of oil-fired furnaces could be raised by 10 to $15 \%$ through improved maintenance. Similar data have not been found for gas-fired furnaces, but research on energy use in a new community in New Jersey ${ }^{14}$ has revealed a $25 \%$ spread in. efficiencies in gas heating in almost.identical awellings. The operation of the less efficient units could probably be improved through better maintenance.

Scenarios: 1. Base Case. Market forces result in better maintenance of space heating furnaces. Average efficiencies in 1985 improve by $5 \%$ for gas and oil furnaces, implemented at $1 \%$ of existing housing stock per year to 1985 .

2. Moderate Case. Federal, state, and local 
governments encourage improved maintenance by (a) providing more comprehensive field data on typical installations, (b) developing a set of "approved" maintenance schedules and procedures, and (c) providing information to the public. Under these assumptions, average efficiencies of renting units improve by. $5 \%$ implemented at $2 \%$ per year to 1985 .

3. Strong case. In addition to the above, some state governments require an annual efficiency inspection similar to auto safety inspections. Implementation rate for improved maintenance increases to $5 \%$ per year to 1985 .

Conservation measure: Improved design of new gas and oil heating systems.

Backqround: Conventional home heating systems are constructed from components made by different manufacturers which are assembled by the contractor with little or no attempt to obtain an optimized system. A unified system featuring improved burner designs that lose less heat out the flue, burn more of the fuel, include heat storage tanks, more flexible controls, etc., has the potential of improving the overall efficiency of heating systems by an additional $20 \%$. $^{15}$

Scenarios: For all three cases, new unit efficiencies improve: by $10 \%$ over current efficiencies by 1985. No improvement's thereafter.

Conservation measure: Solar energy for space and water heating. Background: A study by Westinghouse special systems ${ }^{16}$ shows that solar energy for space and water heating can beciome competitive in most regions of the country in the 1985-2000 period. The Northeast is identified as a primary market because of its high population density and annual heating requirements. It is economically 
impractical, however, to design solar systems to provide $100 \%$ of the heating requirements of buildings. The size of a solar collector to absorb, and a storage subsystem to hold, enough energy to carry the building through protracted periods of cloudy days would be so great that the cost would be prohibitive. Solar systems therefore require conventional components such as gasor oil-burning furnaces as auxiliary systems. It was estimated that solar systems providing $50 \%$ of the space heat and $95 \%$ of the water heat would be economically feasible for the Northeast region.

Scenarios: 1. Base Case. Solar energy is not used on a significant scale to replace conventional fuel for space and water heating.

2. Moderate case. 25\% of new homes and commercial buildings built between 1985 and 2000 receive bU\% ot their space heating requirements from solar systems. For water heating, solar energy supplies $35 \%$. This level of implementation calls for technological improvements to reduce solar system equipment costs.

3. Strong case. The percentage of new homes and commercial buildings utilizing solar systems for space heating increases to 50\%. For water heating, solar energy supplies $20 \%$ of the requirement for homes built between 1972 and 1985 and $70 \%$ for homes and commercial buildings built between 1985 and 2000 . This level of implementation would require government action to provide incentives such as income tax credits or reductions, lowcost insured loans, or government-guaranteed loans.

Conservation measure: Use of electric heat pumps instead of resistance heating.

Background: A heat pump is basically a modified air-conditioning system in which functions of the evaporator and the condenser can be interchanged to it to heat or cool the desired space. The 
coefficient of performance of current heat pumps varies between 2 and $3.5,17$ That is, for every Btu a heat pump consumes in electricity, it produces two or three in heating. It was assumed in this study that a new home with a heat pump would be 2.8 times as efficient as existing resistance-heated homes. If problems of reliability are solved, heat pumps could be highly competitive with electric resistance systems in life-cycle cost effectiveness and minimum energy consumption.

Scenarios: 1 . Base Case. $50 \%$ of new electric homes built between 1985 and 2000 use heat pumps.

2. Moderate Case. $20 \%$ of nèw electric homes built between 1972 and 1985 and $70 \%$ of those built from 1985 to 2000 use heat pumps.

3. $40 \%$ of new electric homes built between 1972 and 1985 and $100 \%$ of those built from 1985 to 2000 use heat pumps. Significant improvements in heat-pump compressor reliability would occur.

Conservation measure: Reduced heating and cooling levels, improved operating procedures, improved efficiencies in new commercial buildings.

Background: In the commercial sector, the more complicated interrelationships between energy demands and building structures do not permit easy analysis of the effect of the various conservation measures applicable to this sector. A.D. Little ${ }^{6}$ estimates that reductions of 15 to $35 \%$ in energy requirements of existing commercial buildings and 15 to $50 \%$ in new construction can be achieved by employing such energy conservation measures as reduced . heating and cooling levels, improved operating procedures, retrofits, and improved design of new buildings and utilizing devices. Improved 
design commonly involves reduction in glass area, better insulation, better building orientation, solar shading schemes, and incorporation of heat recovery schemes. Improved operating procedures can be achieved through a periodic maintenance program, minimized partial load operation, and nighttime setbacks.

Scenarios: 1. Base case. Average demand is reduced by $15 \%$ in all commercial buildings in 1985 and 2000 for space heating and $10 \%$ for cooling.

2. Moderate Case. $20 \%$ reduction in heating demand is achieved in existing buildings and $35 \%$ in new buildings for 1985 and 2000 ; 10\% for cooling.

3. Strong case. $25 \%$ reduction in heating demand for existing buildings is achieved for 1985 and 35\% reduction for 2000; 50\% in new buildings for 1985 and 2000. Cooling demand is reduced by $10 \%$ for 1985 and 2000 in all commercial buildings. 


\section{APPENDIX A}

\section{FUEL MIX TABLES}

Projections of energy demands in this report have been made on a detailed end-use, or disaggregated, basis in order to evaluate technologies or energy policies that may apply to specific end uses. To evaluate the use of heat pumps for space heating, for example, the system efficiency of an electric-resistance heated home may be upgraded and the reduction of fuel demand calculated through this framework. Projections made in this disaggregated manner may underestimate the total energy demand in the future because of unanticipated new uses of energy. However, such additional demands, as they become known, can readily be incorporated into the demand projection by upgrading the unit basic demand of miscellaneous end use in the residential and commercial sectors.

The projections of energy demands and the fuel mix for the reference years are developed in the fuel mix tables included in this appendix. Before describing the methodology used to develop the projections, it is useful to define several parameters :

1. Fuel demand, $D_{i}$, is the quantity of a fuel, * $i$, actually consumed in a specific demand category, such as residential space heating or commercial air conditioning.

2. Total fuel demand, $D_{s}$ is the total fuel reguired to satisfy the requirements of a specific demand category. Electricity is considered as a fuel in this sense and $D_{s}=\sum_{i} D_{i}$.

* "Fuel" as used in this sense includes electricity. 
3. Relative system efficiency, $e_{i}$, is the relative effectiveness with which fuel, $i$, is used in a demand category. This parameter depends on the utilization technology employed. For space heating, $e_{i}$ is defined as 1 for existing electrically heated homes. The values of $e_{i}$ for other structures are given in the fuel mix tables.

4. Degree of saturation, $S$, is the fraction of the potential demand for a. particular energy use actually being fulfilled at a given time. For example, if 95\% of all households have refrigerators and the potential demand for refrigerators is taken to be one per house, $S=0.95$.

b. Unit Energy Demand, $E_{u}$, is the amount ot energy per unit that would be required for a specific end use, assuming a relative system etticiency, $e_{i}$, of $100 \%$ for each fuel employed. Thus, for a given end use, the actual fuel demand per unit is $\mathrm{E}_{\mathrm{u}} / \mathrm{e}_{i}$, where $e_{i}$ is the actual relative system efficiency.

6. Fuel fraction, $f_{i}$, is the fraction of the total number of energy consuming units (basis) that is satisfied by using the i-th fuel.

The unit basic demand derived for each end use is independent of $e_{i}$ and is projected on the basis outlined in Table 18. By specifying the fuel fraction, $f_{i}$, and relative system efficiency, $e_{i}$, the fuel demands, $D_{i}$, can be derived by the equation:

$$
D_{i}=E_{11} \times S \times b \times f_{i} \div e_{i} \text {, The sperifir assumptions }
$$

made in each demand category and the basis for the base-case projection are described on the worksheets that follow. 
FUEL MIX TABLE A-1

Region: I

Scetor: RUSTDIENATAL

Cate $\varepsilon_{i}$ ry: SIMGLE FAMILY DETACHED

End use: SPACE HEATING

DIRECT FUEL USE

METHLANE

Existing

Retrofitied

New-improved

New-FHA-MPS

FUEL OIL

Existing

Retrofitted

New -improved

New-FHA-MPS

ELECTRICITY

Existing

New- Improved

Heat pump

OTHER

TOTAL FUEL DEMAND, D, $10^{12} \mathrm{Btu}$

BASIS , $10^{3}$ Households

SATURATION, S

UNIT BASIC DEMAND, $\mathrm{E}_{\mathrm{u}}$, $10^{6} \mathrm{Btu} /$ household

REFERENCE TECHNOLOGTES:

DATA SOURCES :

BASIS OF PROJECTION S:

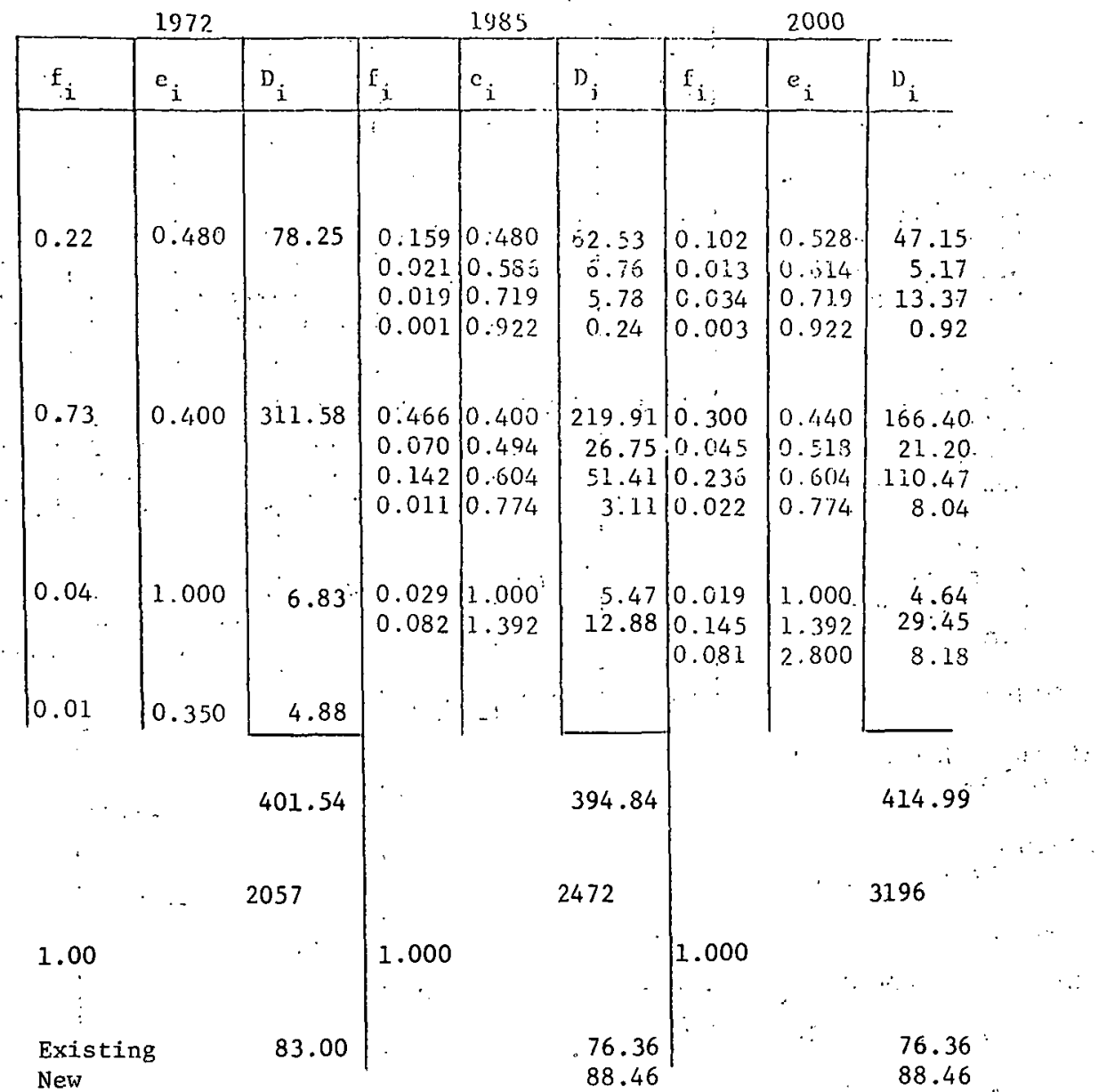

Fossil fuel burners, electric resistance heat and heat pump.

$D_{i}, f_{i}, e_{i}$, and $E_{u}$ for 1972 were obtained from ref. 2 .

The basic unit demand for all housing units. was reduced by $7 \%$ through thermostat setback from $72^{\circ} \mathrm{F}$ to $70^{\circ} \mathrm{F}$. For new housing units estimate of basic unit demand was based on an average house size of $1600 \mathrm{ft} .{ }^{2}$ Improved system efficiencies were obtained from ref. 7. It was assumed that $30 \%$ of all new houses between 1972-1985 will be electrically heated and $50 \%$ thereafter. It was also assumed that $50 \%$ of the new electrically heated homes built after 1985 will use heat pumps. Natural gaa lise. was kept at the 1972 consumption level, with the remaining demand met by oil. Coal use and solar energy were assumed to be negligible. 
FUEL MIX TABLE A-2

Region: I

Sector: RESIUENTIAL

Categ.ory: LOW DENSITY

End use: SPACE HEATING

DLRECT FUEL USE

METHANE

Fristing

Retrofitted

New-improved

New-FIA-iPS

FUEL OIL

Existing

Retrofitted

New-iriproved

NCW-FHA-TPS

ELECTRICITY

Existing

New-improved

Heat pump

OTHER

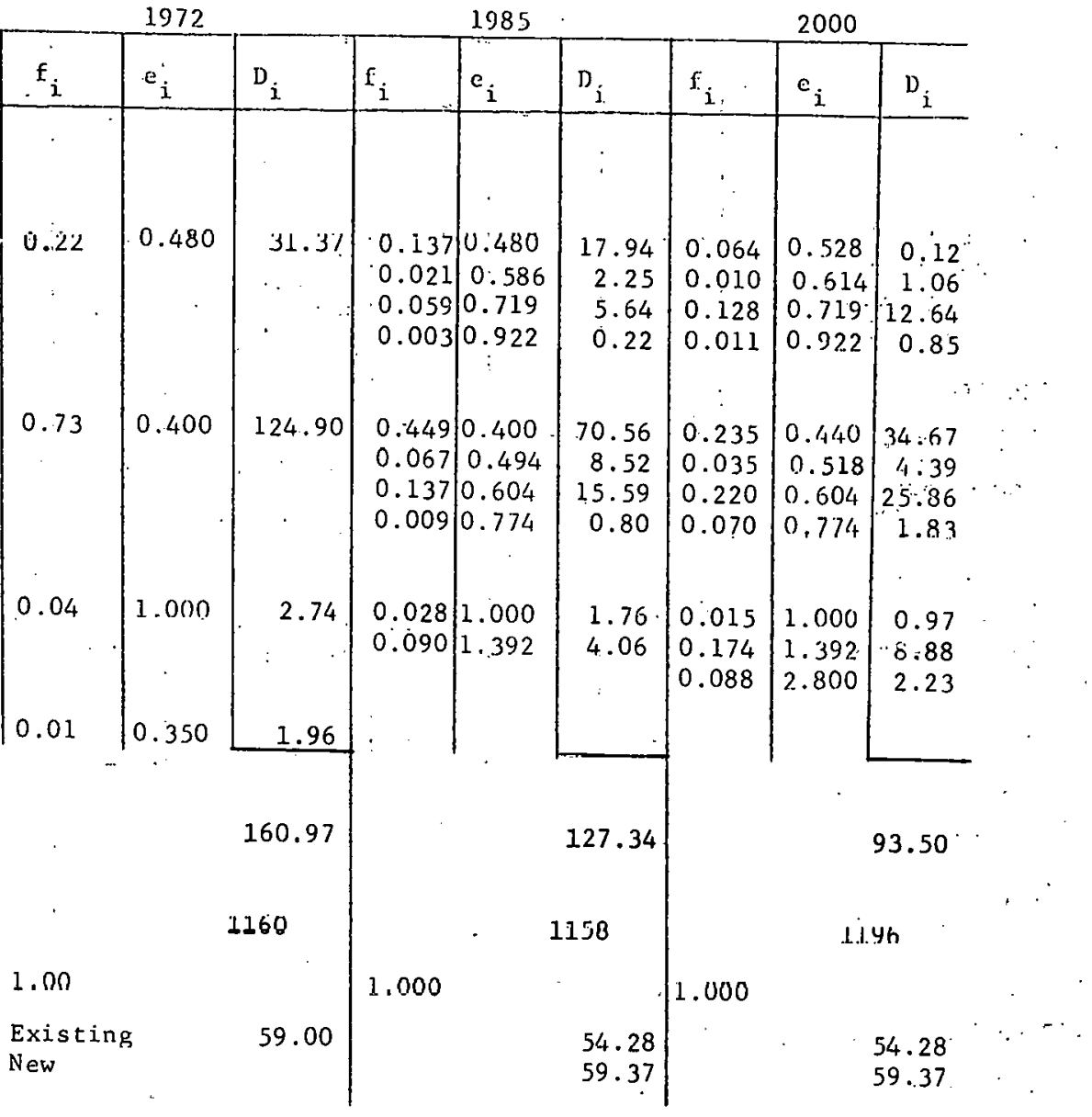

REFERENCE TECHNOLOGIES:

DATA SOURCES:

See Table $A-1$.

See Table A-1.

BASIS OF PROJECTION : Same as in Table $\mathrm{A}-1$ except that average unit size was assumed
to be $1100 \mathrm{ft} 2$. 
FUEL MIX TABLE A-3

Region: I

Sector: RESLUENTIAL

Categury: LOW RISE

End use: SPACE HEATING

DIRECT FUEL USE

METHANE

Existing

Retrofitted

New-improved

New-FHA-MPS

FUEL OIL

Existing

Retrofitted

Nev-jmp roved

New-FHA-iPS

ELECTRICITY

Existing

New-improved

Heat pump

OTHER

TOTAL FUEL DEMAND, D, $10^{12} \mathrm{Btu}$

BASIS

$10^{3}$ households

SATURATION, S

1.00

UNIT BASIC DERLAND, $E_{u}$,

$10^{6} \mathrm{Btu} /$ household

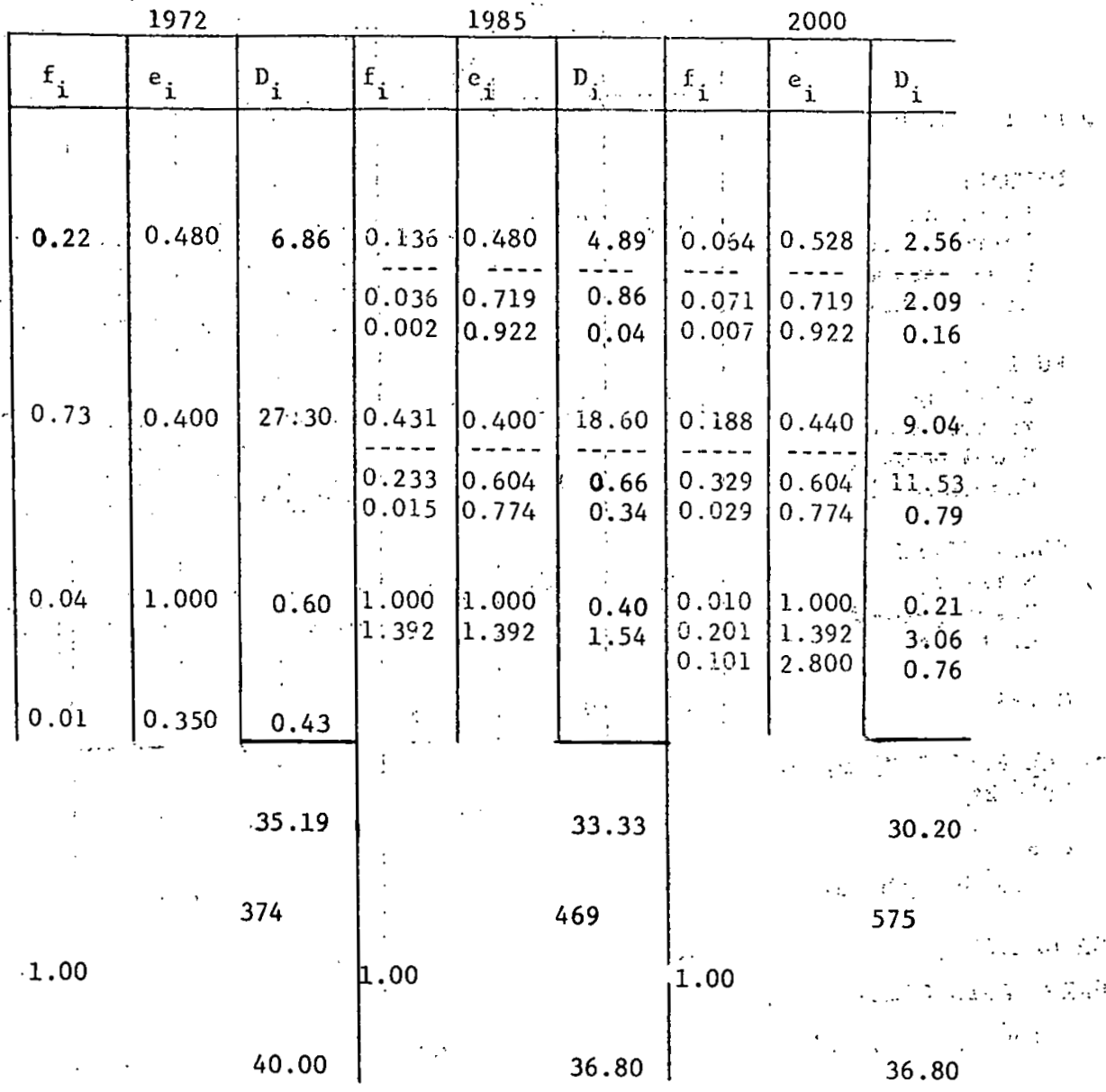

REFERENCE TECHNOLOGIES:

DATA SOURCES:

BASIS OF PROJECTION:

Seè Table A-1.

Same as in Table A-l, except that àverage unit size was assumed to be $900 \mathrm{ft}^{2}$. 
FUEL MIX TABLE A-4

Region: I

Sector: PESIDENTIAL

Category: HIGH RISE

End use: SPACE HEATING

DIRECT FUEL USE

METHANE

Existili:

Retrofitted

New-improved

New-FHA-MPS

FUEL OTLL

Existing

Retrofitted

New-Improved

New-FHA -MPS

ELEC'TRICITY

Existing

New-improved

Heat pump

OTHER

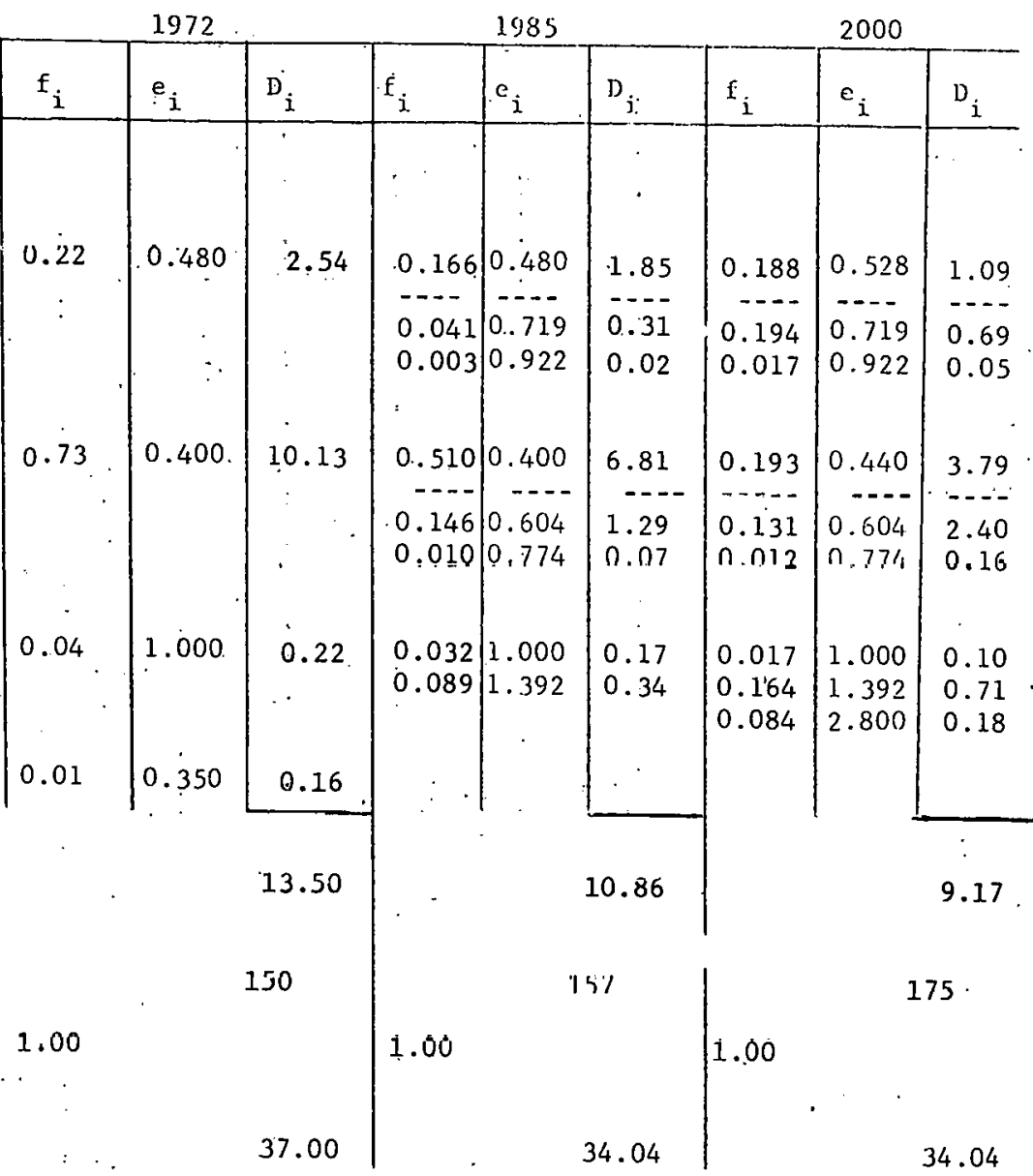

REFERENCE TECHNOLOGTES:

DATA SOURCES:

See Table A-l.

BASIS OF PROJECTION :

Same as in Table A-3. 
Region: I

Scctor: RESIDENTTAI

Category: MOBILE HOMES

End use: SPACE HEATING

DIRECT FUEL USE

METHANE

Existing

Retrofitted

New-improved

New - FHA - MPS

FUEL OIL

Existing

Retrofitted

New-improved

New-FHA-MPS

ELECTRICITY

Existing

New-improved

Heat pump

OTHER

TOTAL FUEL DEMAND, D, $10^{12} \mathrm{Btu}$

BASIS

$10^{3}$ households

SATURATION, S

UNIT BASIC DEMAND, $\mathrm{E}_{\mathrm{u}}$, $10^{6}$ Btu/household

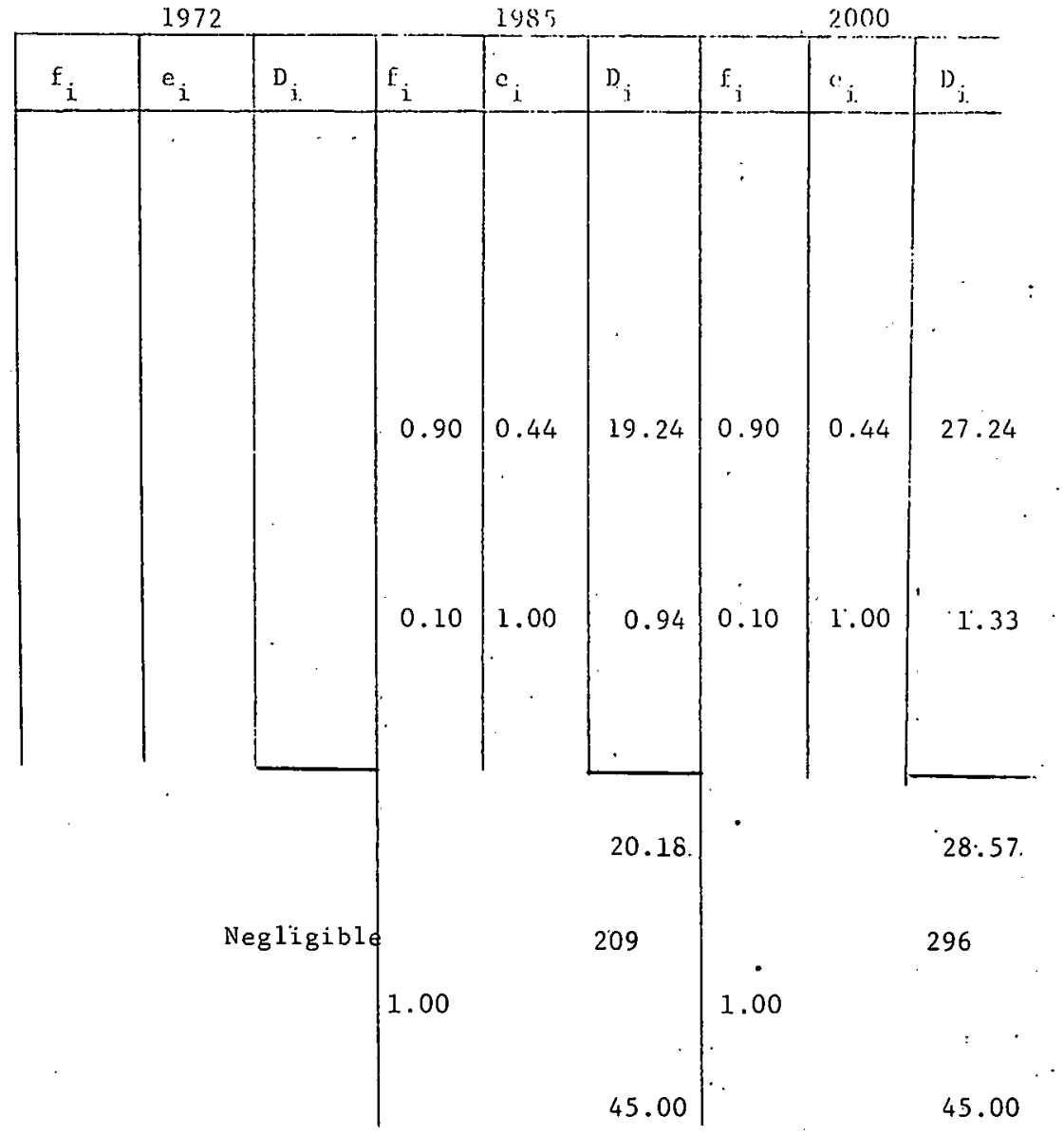

REFERENCE TECHNOLOGIES:

DATA SOURCES :

Fossil fule burners, electric resistance heat.

$f_{i}$, ref. $6 ; e_{i}$, ref. 7 .

BASIS OF PROJECTION:

Estimates of future $f_{i}$ 's were based on current fuel mix.. 
FUEL MIX T/BILE A-6

Region: I

Sector: RESTIJENSSAL

Category: ALL HOUSING TYPES

End use: AIR CONDITIONTNG

DIRECT FUEL USE

METHANE

Existing

Ketrotitted

New-improved

Ner-FHA-MPS

FUEL OIL

Fxisting

Retrofitted

New-improver

New-FHA-NPS

ELECTRICITY ,

ROOM

CENTRAL

OTHER

TOTAL FUEL. DEMAND, D, $10^{12} \mathrm{Btu}$

BASIS

103 households

SATURATION, S

UNIT BASIC DENAND, Eu

( $10^{6} \mathrm{Btu} /$ household)

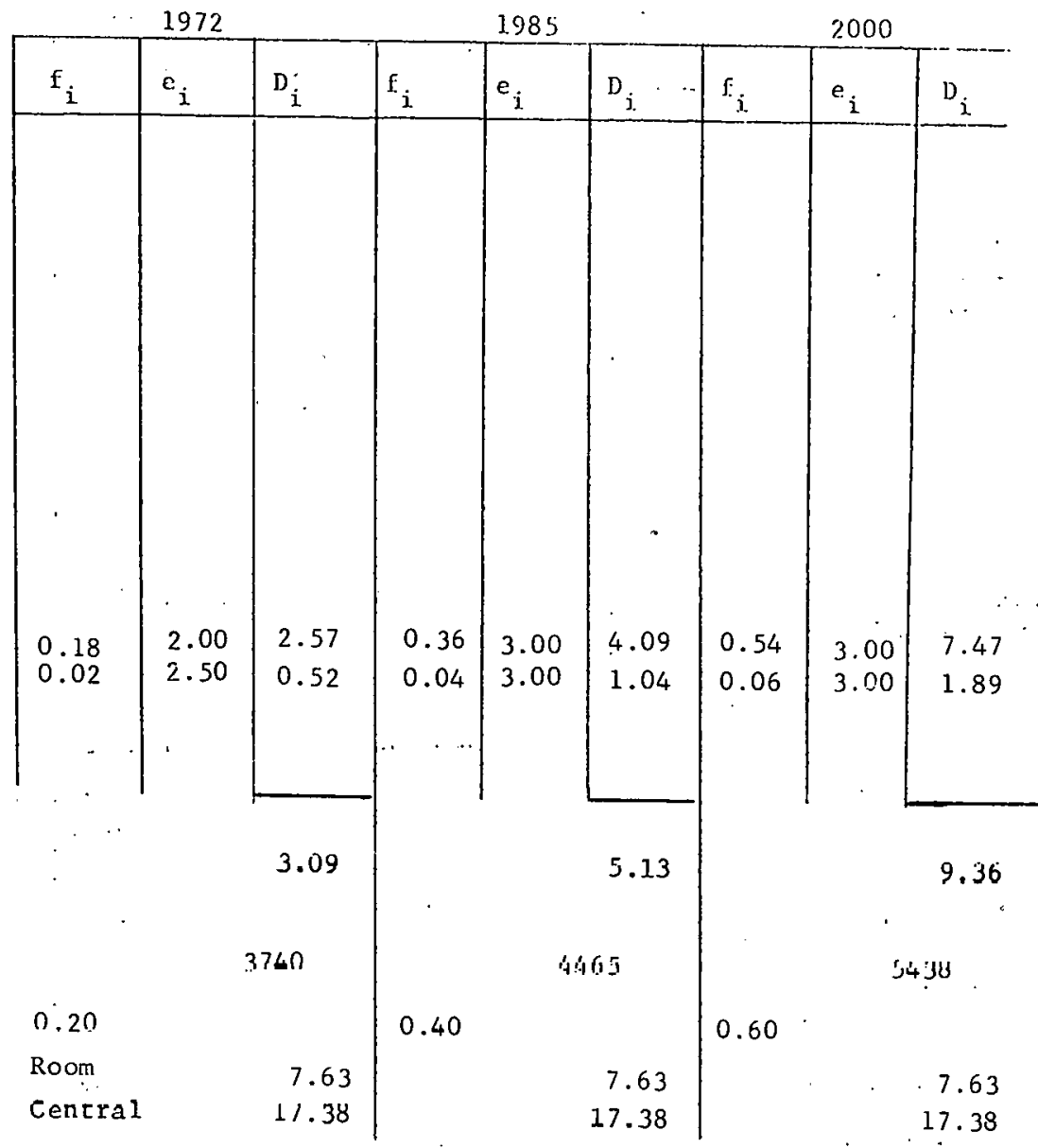

REFERENCE TECHNOLOGIES:

DATA SULRCES:

Vapor compression cycle operating on electricity.

BASIS 'OF PROJECTION :

$S$ for 1972 and $E_{u}$ were obtained from ref. 2 .

$\mathbf{E}_{\mathbf{u}}$ for 1985 and 2000 were kedt at the same level as in 1972 . Sacuration were upgraded on the baois of projertions given in refs. 2 and 6 . 
FUFL MIX TABLE

A-7

Region: I

Sector: RESTIDINTTIAI,

Category: SITHiLE RAMILY DETACHED

EnC? use: WATER HEATING

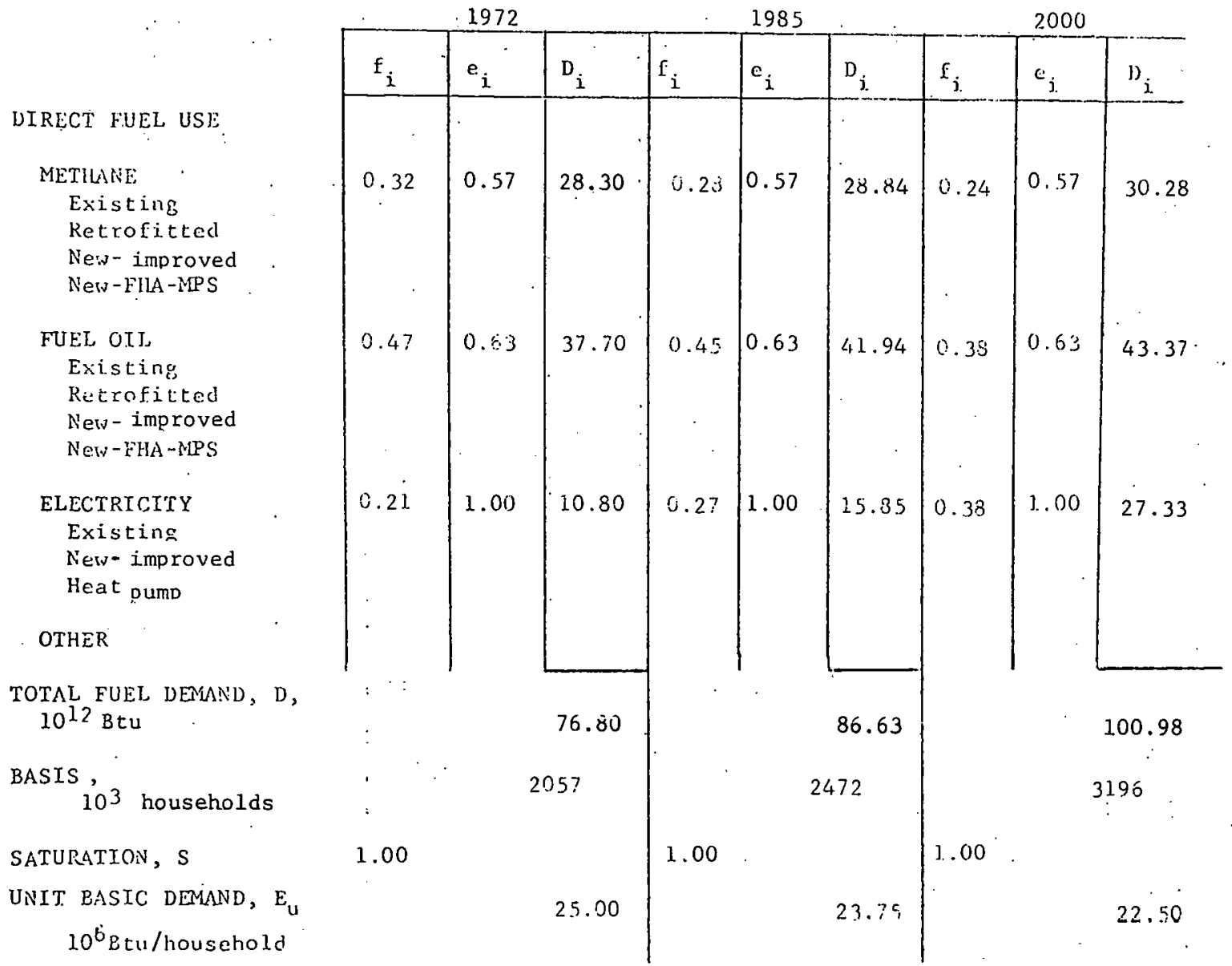

REFERENCE TECHNOLOGIES: Gas and oil burners, eiectric resistañce heat.

DATA SOURCES: $\quad \mathrm{F}_{i}, e_{i}, D_{i}$, and $E_{u}$ for 1972 were obtained from ref. 2.

BASIS OF PROJECTION: Unit basic demand was reduced by $5 \%$ for 1985 and $10 \%$ for 2000 because of the reduction in persons per household. System efficiencies were assumed to be the same as in 1972 . . $f_{i}$ 's for gas and oil were assuned to decrease at the same rate for space heating. 
FUEL MSX INSLE

$$
A-8 \text {. }
$$

Region: I

Sector: REsTHIinTSAL

Categery: LOW DENSITY

End use: WATER HEATING

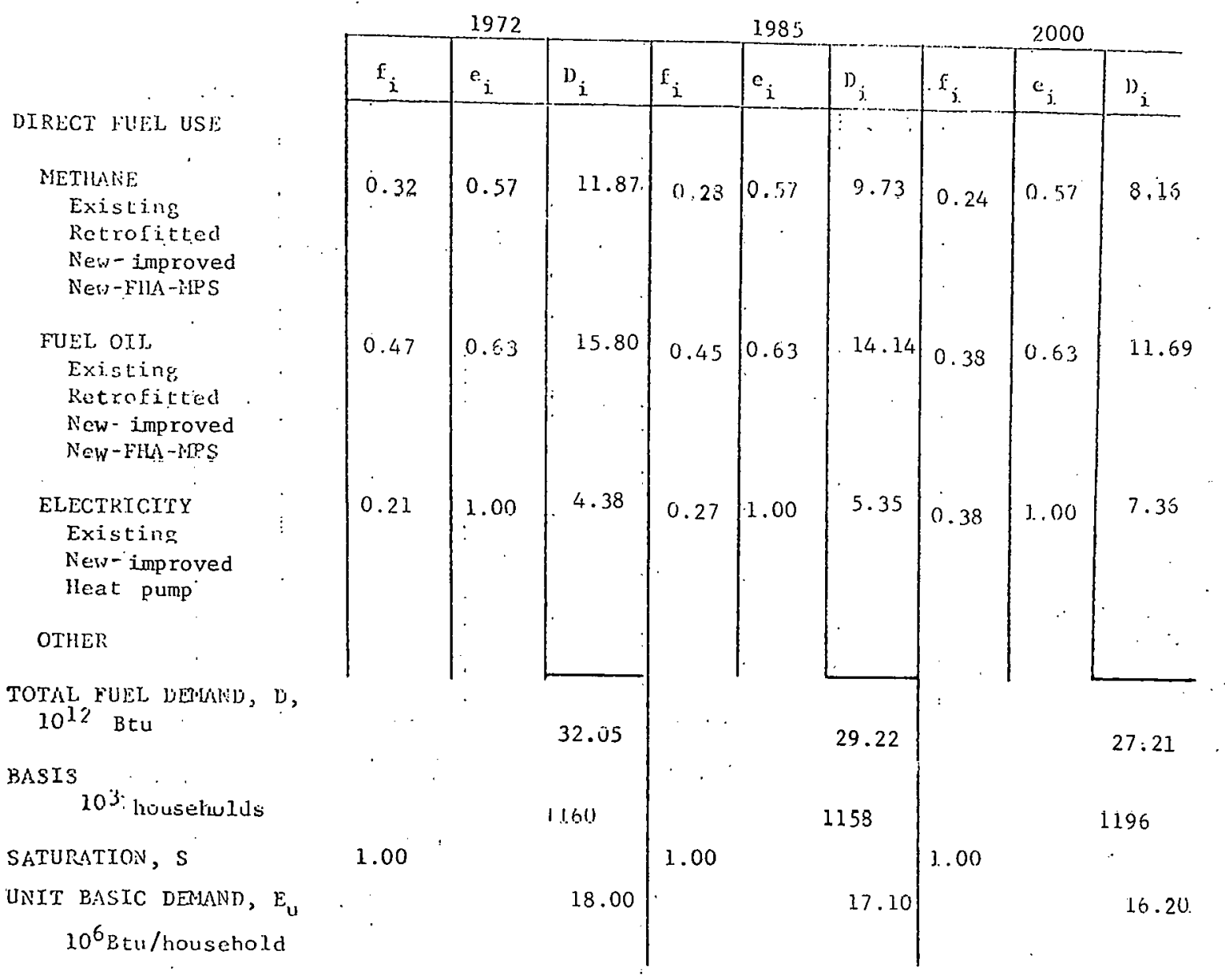

REEERENCE TECHNOLOGIES:

NATA SOULRF.S:

BASIS OF PROJECTION: See Table A-7, 
FUFI, MIX SABIS:

A-9

Region: I

Sector: RESTIJENTCAL,

Catiegory: LOW RISE

End use: WATER HEATING

DIRECT FUEL USE

METHLNE

Existing

Retrofitted

New-improved

New-FHL-MPS

FUEL OrL

Existing

Retrofitted

New-improved

New - FHA - IPS

ELECTRICITY

Existing

Nerv-improved

Heat pump

OTHER

TOTAL FUEL DEMAND, D, $10^{12}$ Btu

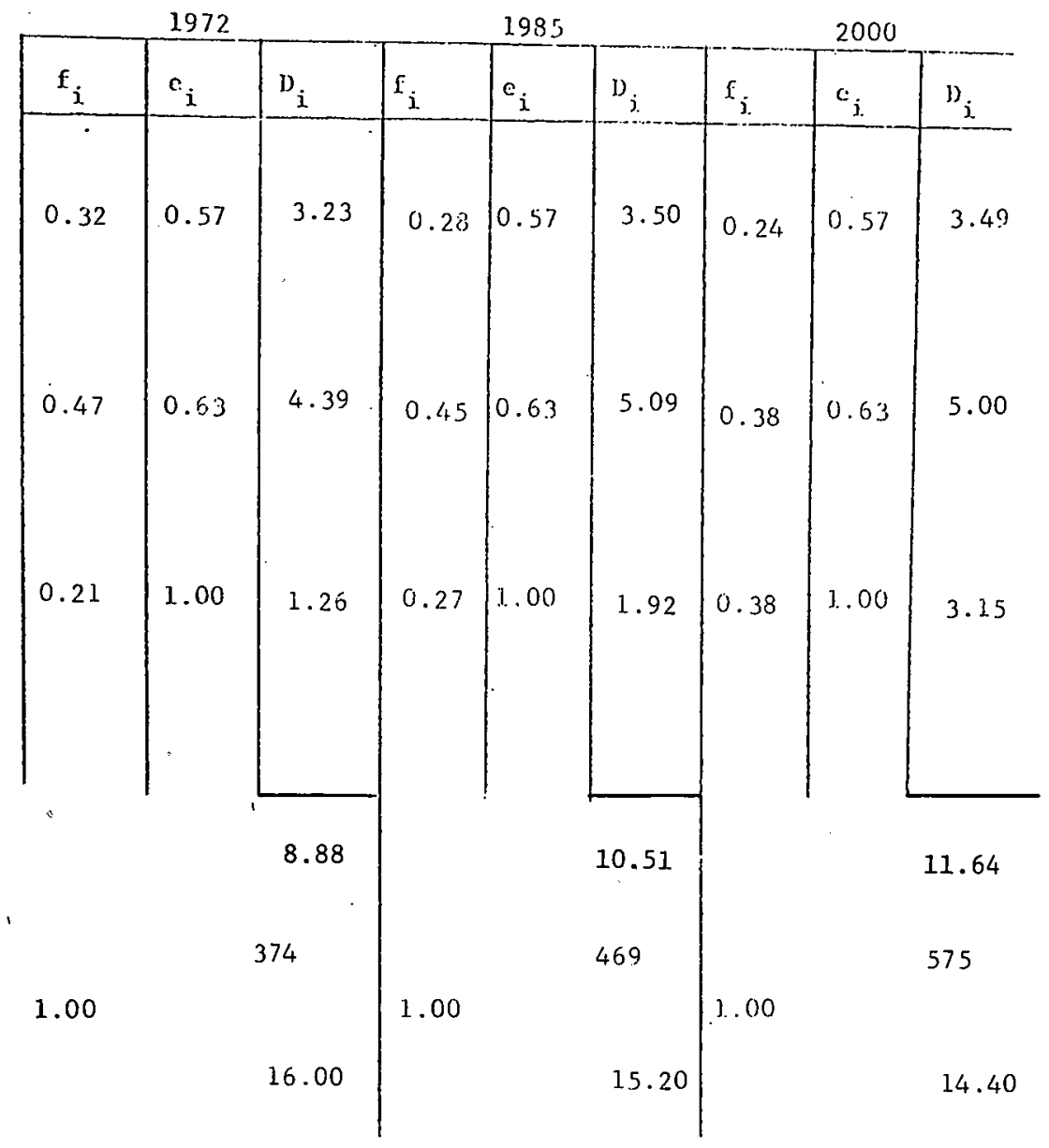

REFERENCE TECHNOLOGIES:

DATA SOURCES:

BASIS OF PROJECTION: See Table A-7. 
FUEL MIX TABLE

A-10

Region: I

Sector: RESTDENTIAT.

Category: HIGH RISE

End use: WATER HEATING

DIRECT FUEL USE METHANE

Existing

Retrofitted

$\mathrm{New}$-improyed

New-FHA-MPS

FUEL OIL

Existing

Retrofitted

New - improyed

New-F'HA-MYS

ELECTRICITY

Existing

New - improyed

Heat pump

OTHER

TOTAL FUEL DEMAND, D, $10^{12} \mathrm{Btu}$

\begin{tabular}{|c|c|c|c|c|c|c|c|c|}
\hline \multicolumn{3}{|c|}{1972} & \multicolumn{3}{|c|}{1985} & \multicolumn{3}{|c|}{2000} \\
\hline $\mathrm{f}_{i}$ & $e_{i}$ & $\mathrm{D}_{i}$ & $\mathrm{f}_{i}$ & $e_{i}$ & $\mathrm{D}_{\mathrm{j}}$ & $E_{j}$ & $\epsilon_{j}$ & ${ }^{1}{ }_{j}$ \\
\hline 0.32 & 0.57 & 1.29 & 0.28 & 0.57 & $1.1 /$ & 0.24 & 0.57 & 1.05 \\
\hline 0.47 & 0.63 & 1.76 & 0.45 & 0.63 & 1.70 & 0.38 & 0.63 & 1.52 \\
\hline 0.21 & 1.00 & 0.50 & 0.27 & 1.00 & 0.64 & 0.38 & 1.00 & 0.96 \\
\hline & & 3.55 & & & 3.51 & & & 3.54 \\
\hline & & 150 & & & 157 & & & 175 \\
\hline 1.00 & & . & 1.00 & & & $1.00^{\circ}$ & & \\
\hline & & 16.00 & & & 15.20 & & & 14.40 \\
\hline
\end{tabular}

REFERENCE TECHNOJOGIES:

DATA SOURCES:

P.ASIS OF PROJECTION: See Table A-7. 
FUEL MIX TABLE

A-11

Region: I

Sector: RESIDENTIAL

Category: MOBILE HOME

End use: WATER HEATING

DIRECT FUEL USE

METHANE

Existing

Retrofitted

New - improved

New-FHA-MPS

FUEL OIL

Existing

Retrofitted

New - improved

New - FHA -MPS

ELECTRICITY

Existing

New - improved

Heat pump

OTHER

TOTAL FUEL DEMAND, $D$, 1012. Btu

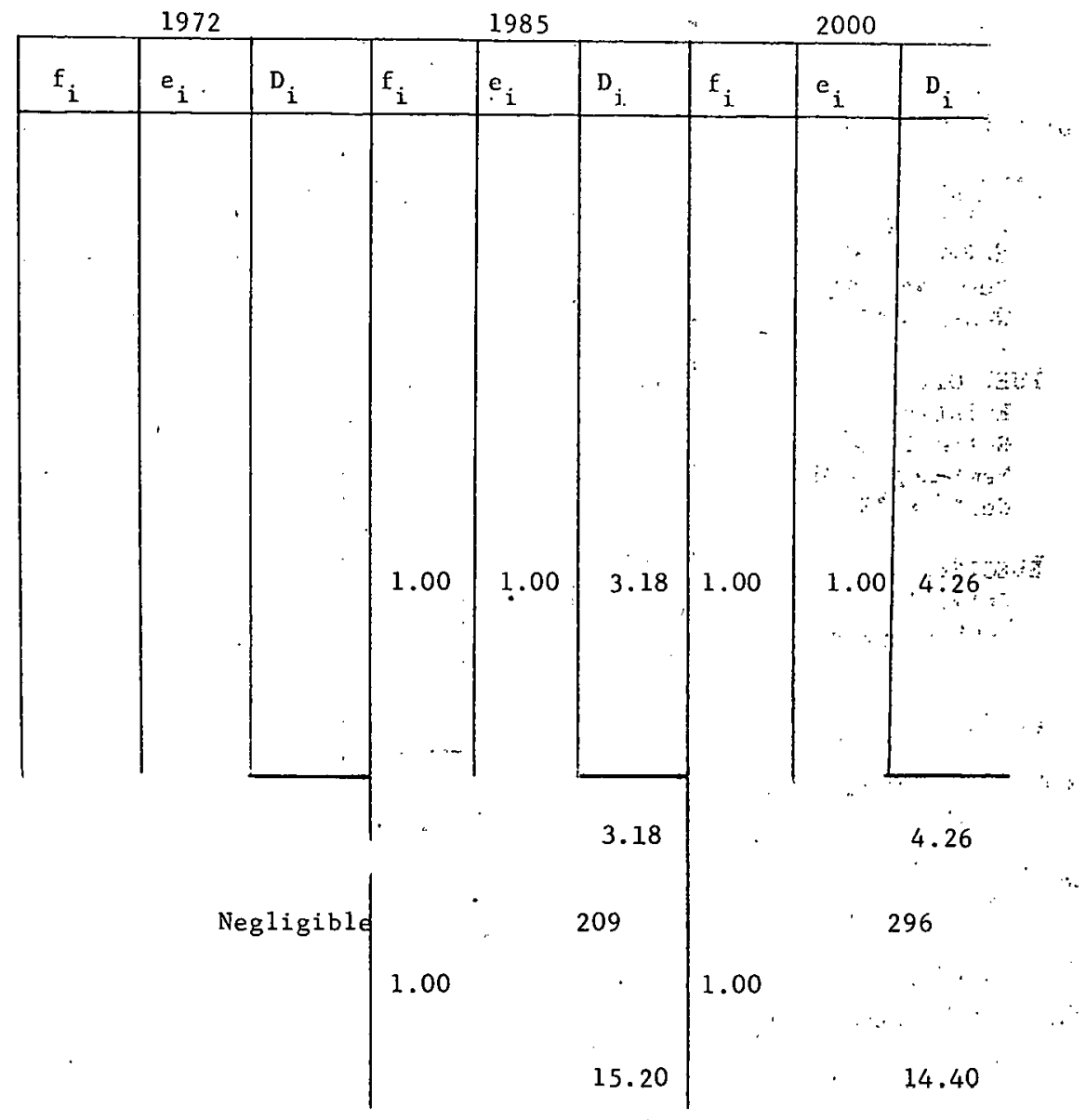

REFERENCE TECHNOLOGIES: Electric resistance heating

DATA SOURCES:

$e_{i}$ was obtained from ref. 2 .

BASIS OF PROJECTION: $\quad \mathrm{E}_{\mathrm{u}}$ was assumed to be the same as in Table A-10; $\mathrm{f}_{i}$ was assumed to be all electric. 


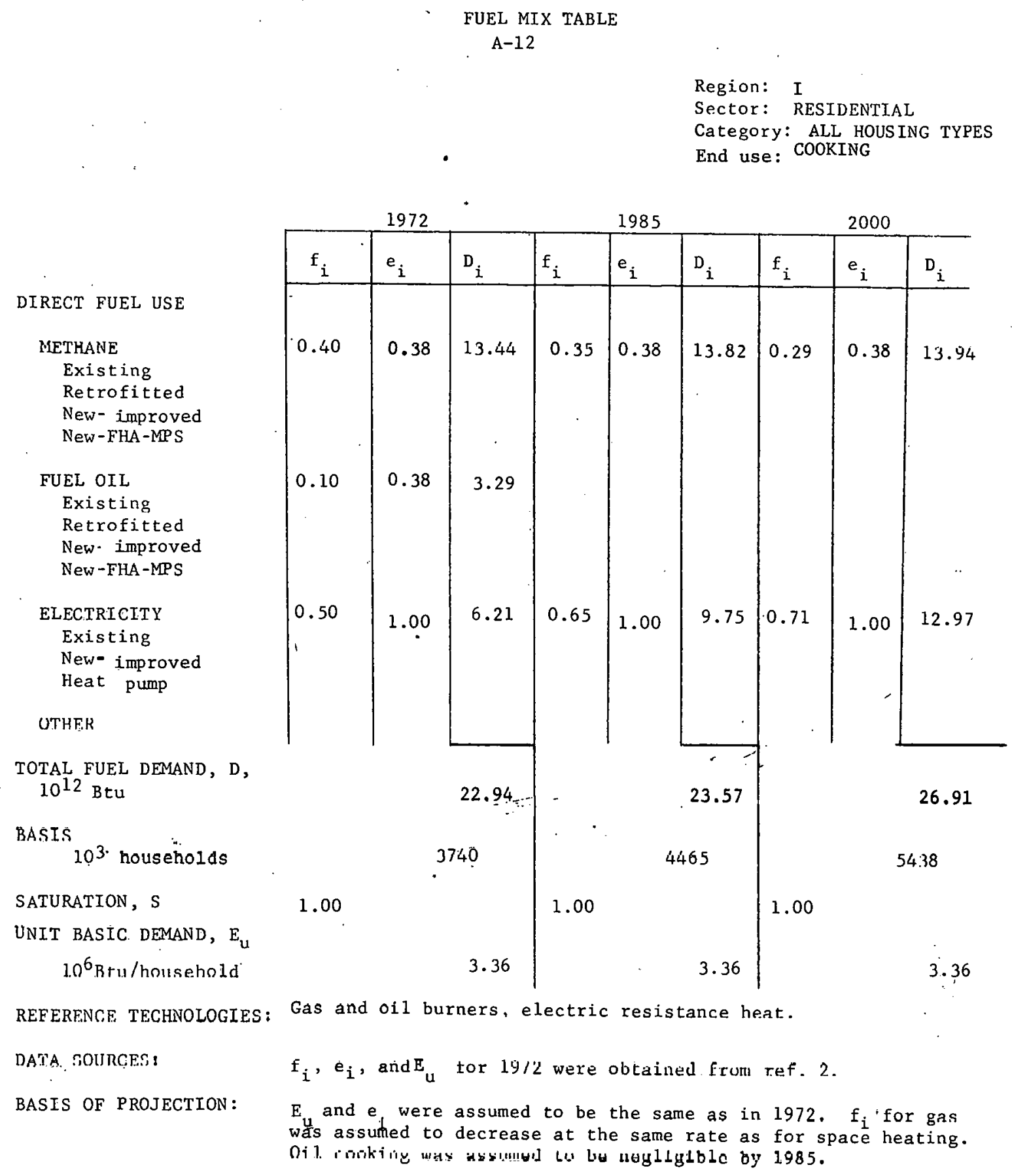


FUEL MIX TABLE

A -13

$\begin{array}{ll}\text { Region: } & \text { I } \\ \text { Sector: } & \text { RESIDENTIAL }\end{array}$

Catezory: ALL HOUSING TYPES

End use: LIGHTING and MISC.

ELECTRIC APPLIANCES

DIRECT FUEL USE

METHANE

Existing

Retrofitted

New-improved

New-FH:' --MPS

FUEL OIL

Existing

Retrofitted

New-improved

New-FHA-MPS

ELECTRICITY

Existing

New - improved

Heat pump

OTHER

TOTAL FUEL DEMAND, D,

$10^{12} \mathrm{Btu}$

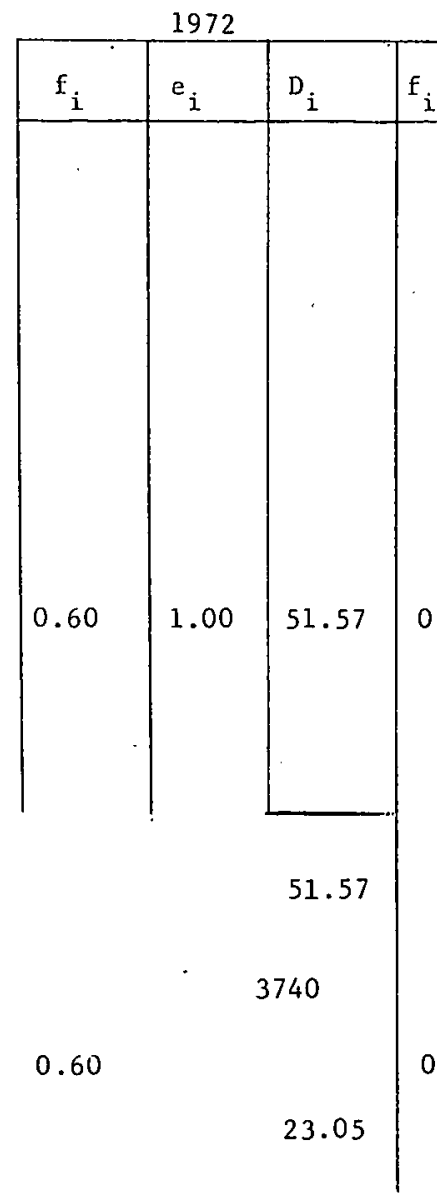

1985

2000

BASIS

$0.73 \quad 1.00$

69.75

0.88

1.00

100.97

$$
\begin{aligned}
& 10^{3} \text { households } \\
& \text { SATURATION, S } \\
& \text { UNIT BASIC DEMAND, } \mathrm{E}_{\mathrm{u}} \\
& 10^{6} \mathrm{Btu} / \text { household }
\end{aligned}
$$

0.73

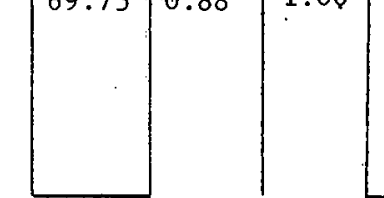

REFERENCE TECHNOLOGIES:

DATA SOURCES :

Conventional lighting technology, AC induction motor, and other undefined uses of electric energy.

$S$ and $E_{u}$ foi 1972 were obtained from ref. 2 .

BASIS OF PROJECTION:

$S$ and $E_{u}$ for 1985 and 2000 were developed in Table 14 . 
FUIEL, HCX TABLE

A-14

Region: I

Sector: COMNERCIAL.

Caticgory: OFFICE

End-uss: SPACE IIEA'IING

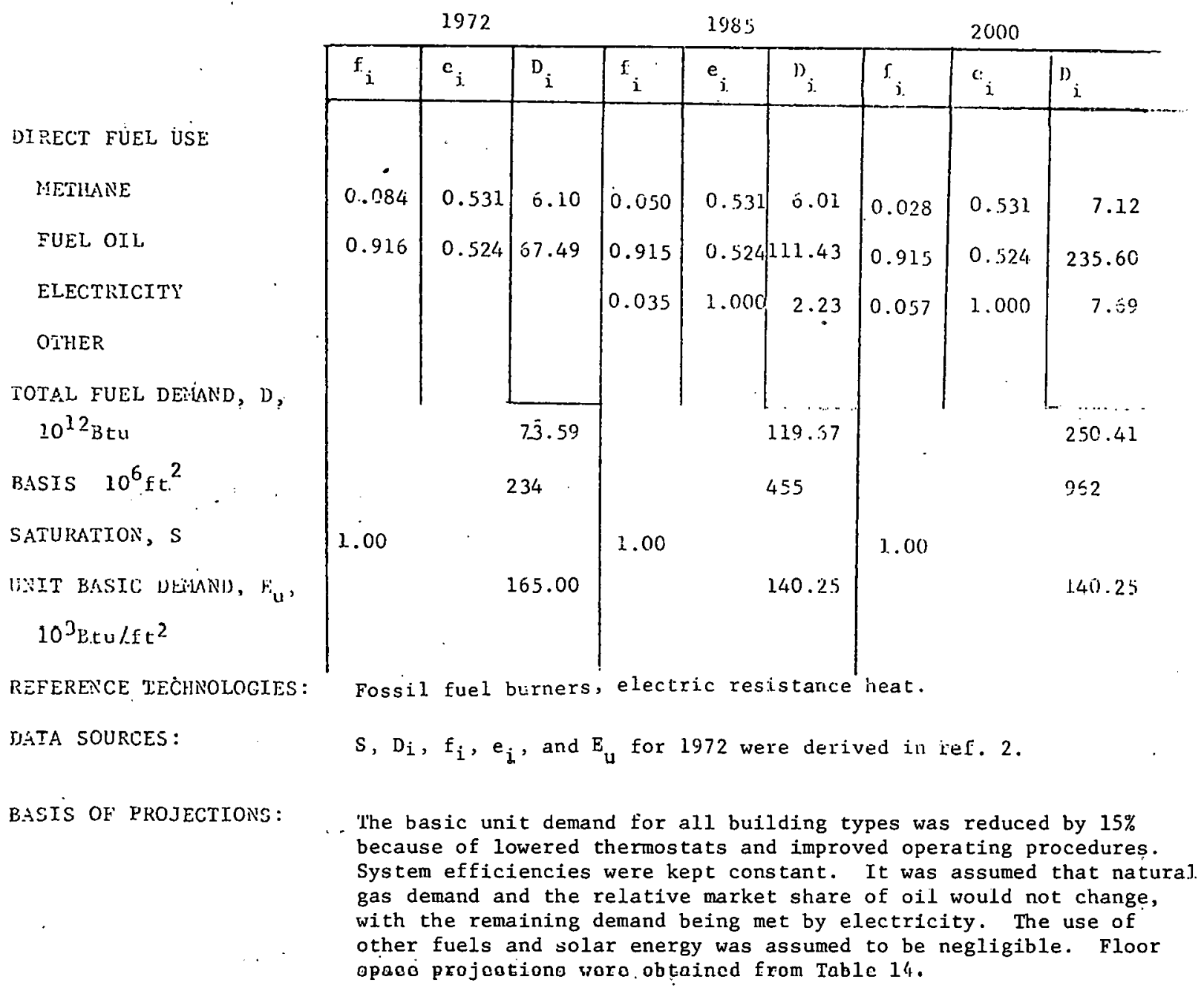


FUIEL, WCX TABLE

A-15

Region: I

Sector: COMNERCLAI.

Caliegory: RETAIL

End-use: SPACE HEATINS

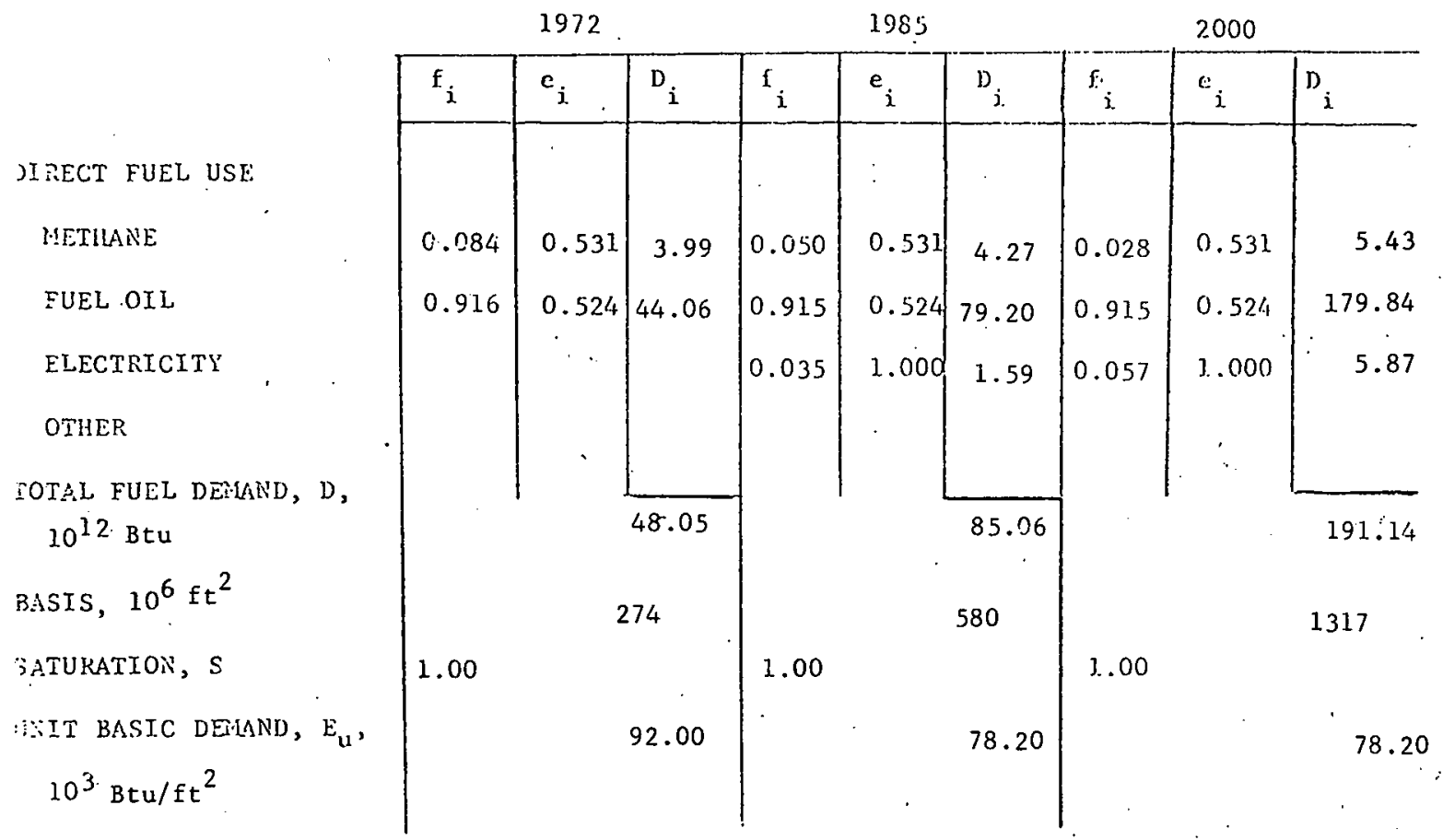

REFERENCE TECHNOLOGIES:

DATA SOURCES:

BASIS OF PROJECTIONS: Siee Table A-14. 


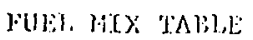

A-16

Resion: 1

Sector: COHMERTAJ

Category: SCHOOL

Fnd-uso: SPACE HEATINS

פIRECT FUEL USE

METILANE

FUEL OIL

ELECTRICITY

OTHER

TOTAL FUEL DEYWIED, D, $10^{12} \mathrm{Btu}$

BASTS $10^{6} \mathrm{ft}^{2}$

SATURATIONE, S

LUIT BASIC DELANU, $\mathrm{r}_{\mathrm{u}}$, $10^{3} \mathrm{Btu}_{\mathrm{tu}} / \mathrm{ft}^{2}$

REFERENCE TECHAOLOGIES:

DATA SOURCES:

E.ASIS OF PROJECTIONS: See Table A-14. 
FUI: HLX MALLE

$$
\text { A }-17
$$

Res;ion: I

Sector: COMNERCJAL

Catcgory: HOSPITAL

Find-usc: SPACE HEATING

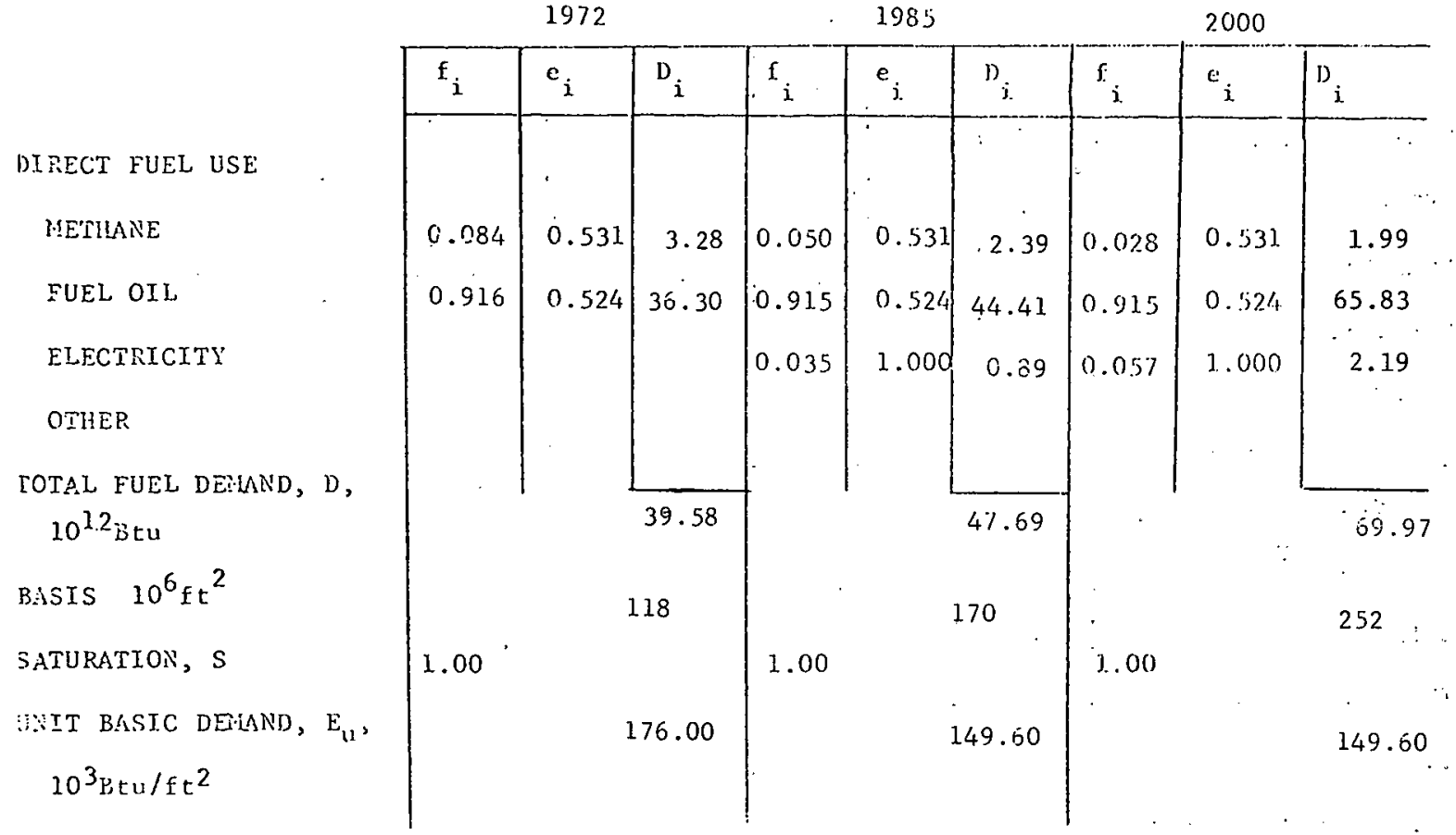

REFERENCE TECHNOLOGTES:

DATA SOURCES:

BASIS OF PROJECTIONS: See Table A-14. 
JUI:L, MLX INALI:

$$
\text { A-18 }
$$

Region:" I

Sector: COMHERCJAL

Cat:czory: MISCELLANEOUS

End-uSC: SPACE HEATLNU

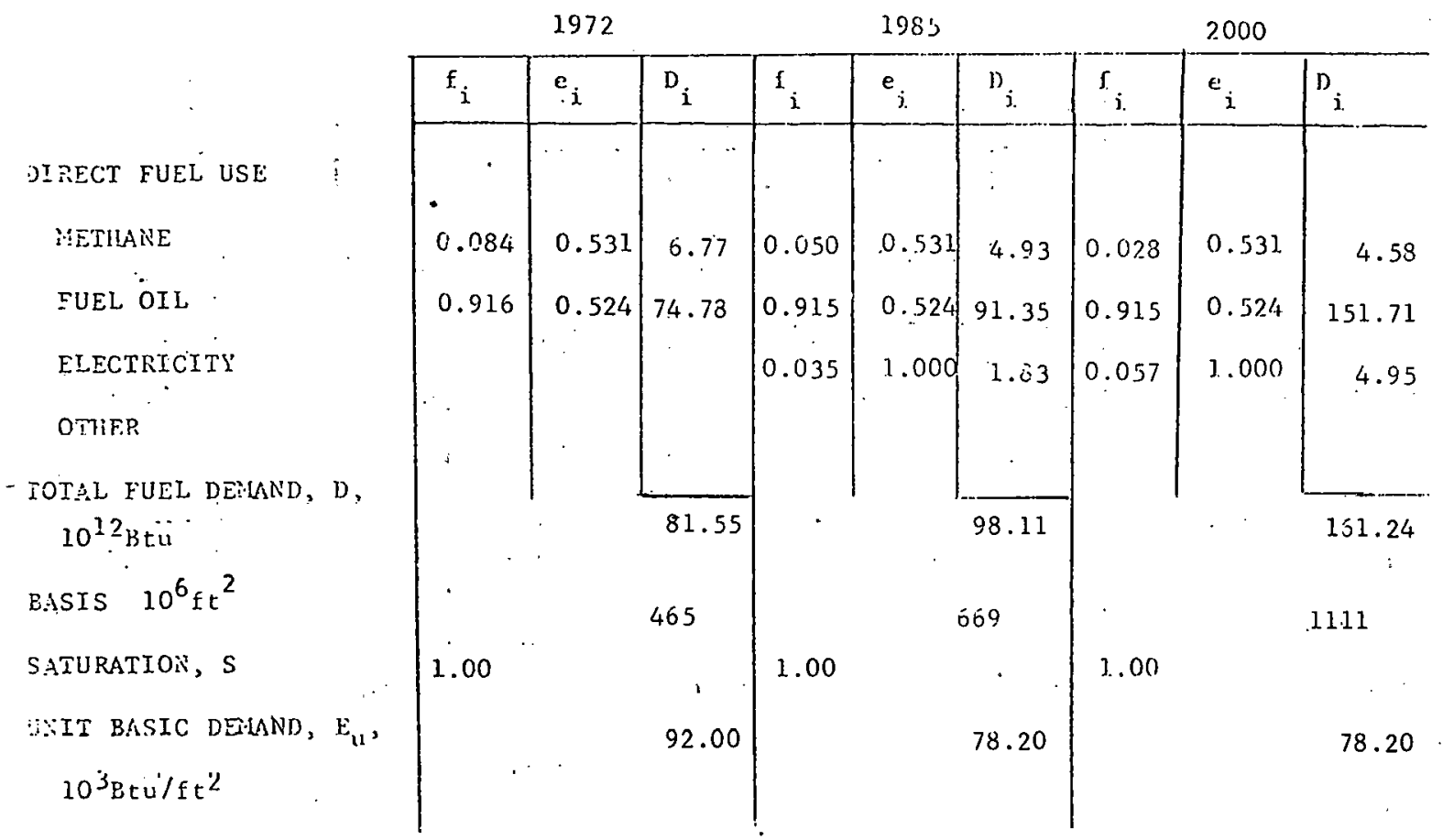

REFERENCE TECHNOLOGIES:

DA'A SUURCES :

EASIS OF PROJECTIONS: See Tab1e A-14. 
FUEL MIX TABLE

$$
\text { A-I9 }
$$

Region: I

Sector: CONMERCIAL

Category: OFFICE

Encl-use: AIR CONDITIONING

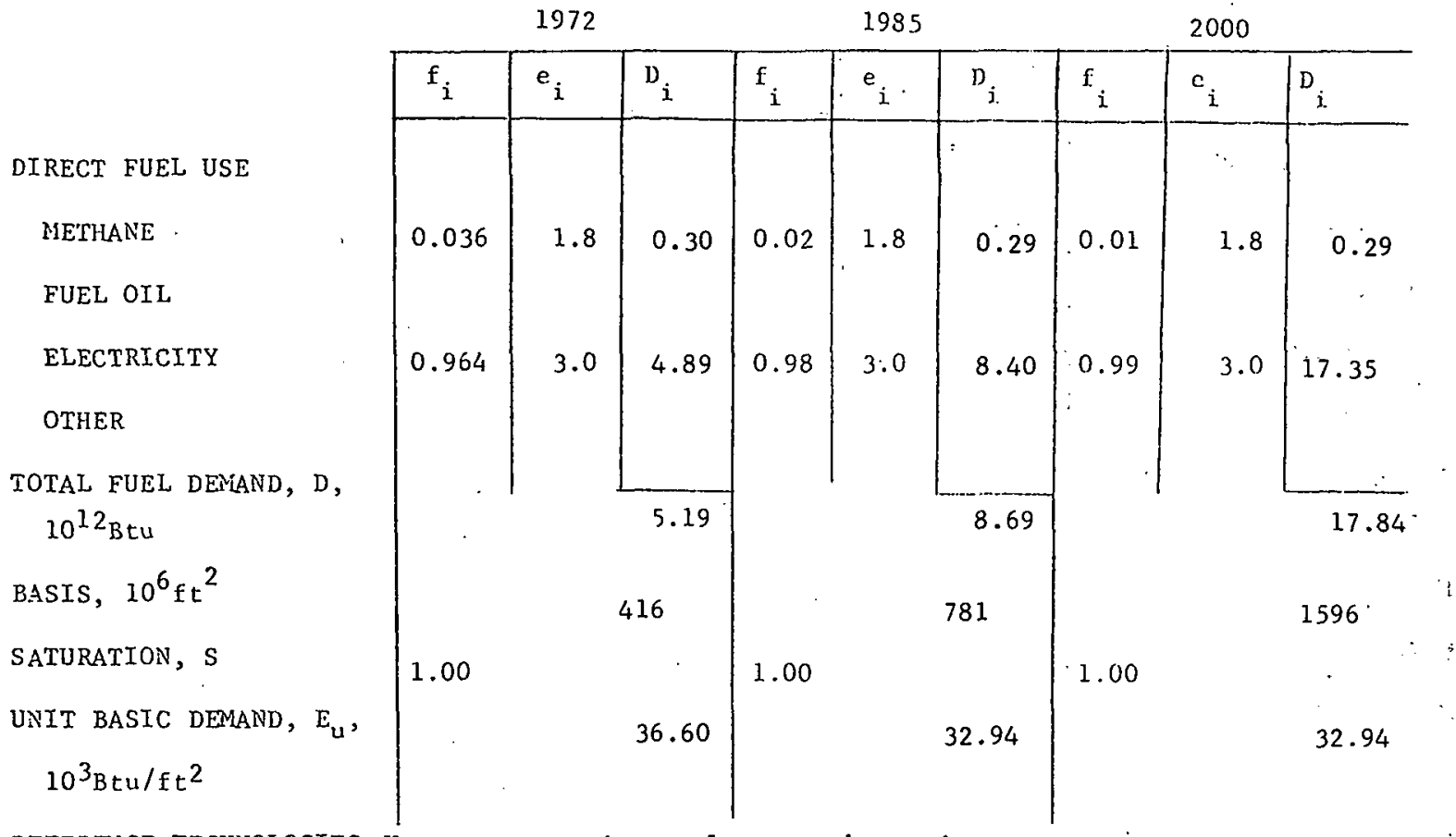

REFERENCE TECHNOLOGIES: Vapor compression cycle, gas absorption.

DATA SOURCES :

$$
D_{i}, e_{i}, f_{i} \text {, and } E_{u} \text { for } 1972 \text { were obtained from ref. } 2 \text {. }
$$

BASIS OF PROJECTIONS: The basic unit demand was reduced by $10 \%$ for 1985 and 2000 because of improved efficiency and operating procedures. Natural gas usage was kept at the 1972 level, with the remaining demand supplied by electricity. Saturation, 8 , was asamed to bc unfty. 
FUEL MIX TABLE

$A-20$

Region: I

Sector: COMMERCIAL

Category: RETAIL

End -use: AIR CONDITIONING

DIRECT FUEL USE

METHANE

FUEL OIL

ELECTRICITY

OTHER

TOTAL FUEL DEMAND, D, $10^{12} \mathrm{Btu}$

BASIS, $10^{6} \mathrm{ft}^{2}$

SATURATION, S

UNIT BASIC DEMAND, $E_{u}$, $1 U^{3} B t u / E t^{2}$

REFERENCE TECHNOLOGIES :

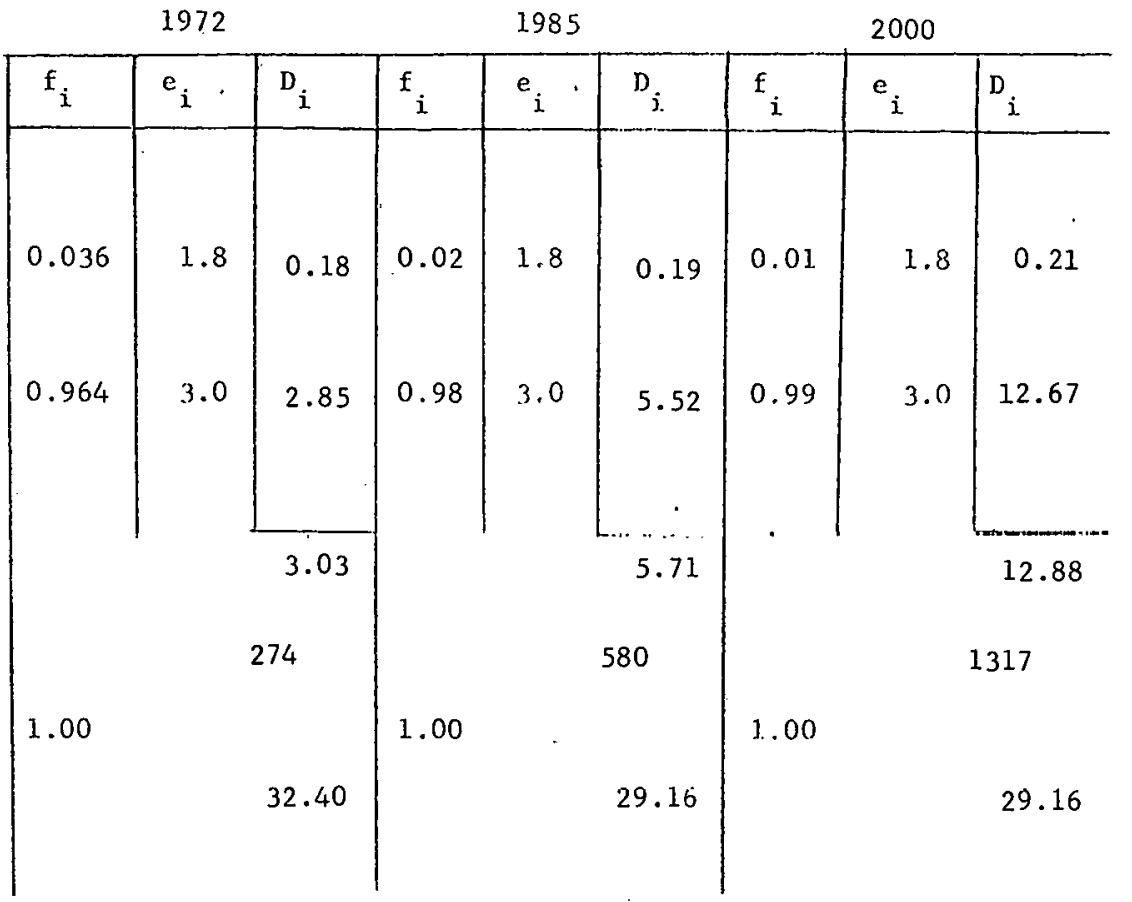

DATA SOURCES:

See Table A-19. 
FUEL MIX TABLE

$A-21$

Regi.on: I

Seclior: COMNERCIAL

Category: SCHOOL

Enduse: AIR CONDITTONLNG

DIRECT FUEL USE

NETHANE

FUEL OIL

ELECTRICITY

OTHER

TOTAL FUEL DEMAND, D, $10^{12} \mathrm{Btu}$

BASIS, $10^{6} \mathrm{ft}^{2}$

SATURATION, S

UNIT BASIC DEMAND, $E_{u}$, $10^{3} \mathrm{Btu} / \mathrm{ft}^{2}$

REFERENCE TECHNOLOGIES:

DATA SOURCES :

See Table A-19.

BASIS OF PROJECTIONS: Same as in Table A-19, except that saturation, S, was assumed to be $30 \%$ by 1985 and $40 \%$ by 2000 . 
FUEL HIX 'INBLE

$$
\mathrm{A}-22
$$

Region: I

Sector: COMVERCTAL

Category: HOSPITAL

Fnd-use: AIR CONDITIONING

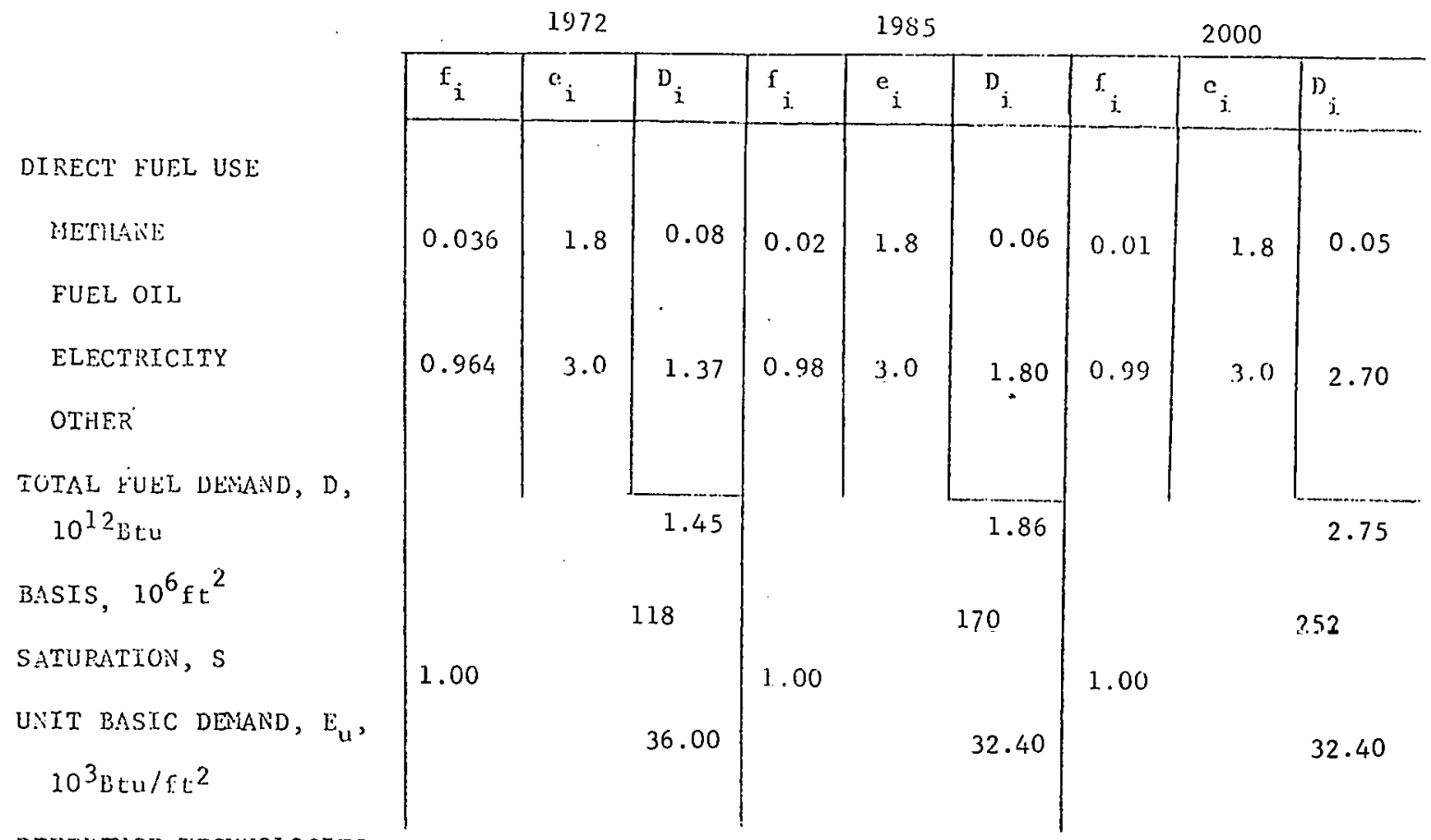

REFERENCF: TRFCHNOTOGTES:

DATS SOUHCES :

BASTS OF PROJECTIONS: See Table A-19. 
FUEL MIX TALTS:

A- 23

Region: I

Sect:or: CONHEIRCLAL

Category: MISCELLANEOUS

End-use: AIR CONDISTONING

DIRECT FUEL USE

NETHANE

FUEI, OIL

ELECTRICTTY

OTHER

SOTAL FUEL DEMAND, D, $10^{12} \mathrm{Btu}$

BASIS, $10^{6} \mathrm{ft}{ }^{2}$

SATURATION, S

972

2985

2000

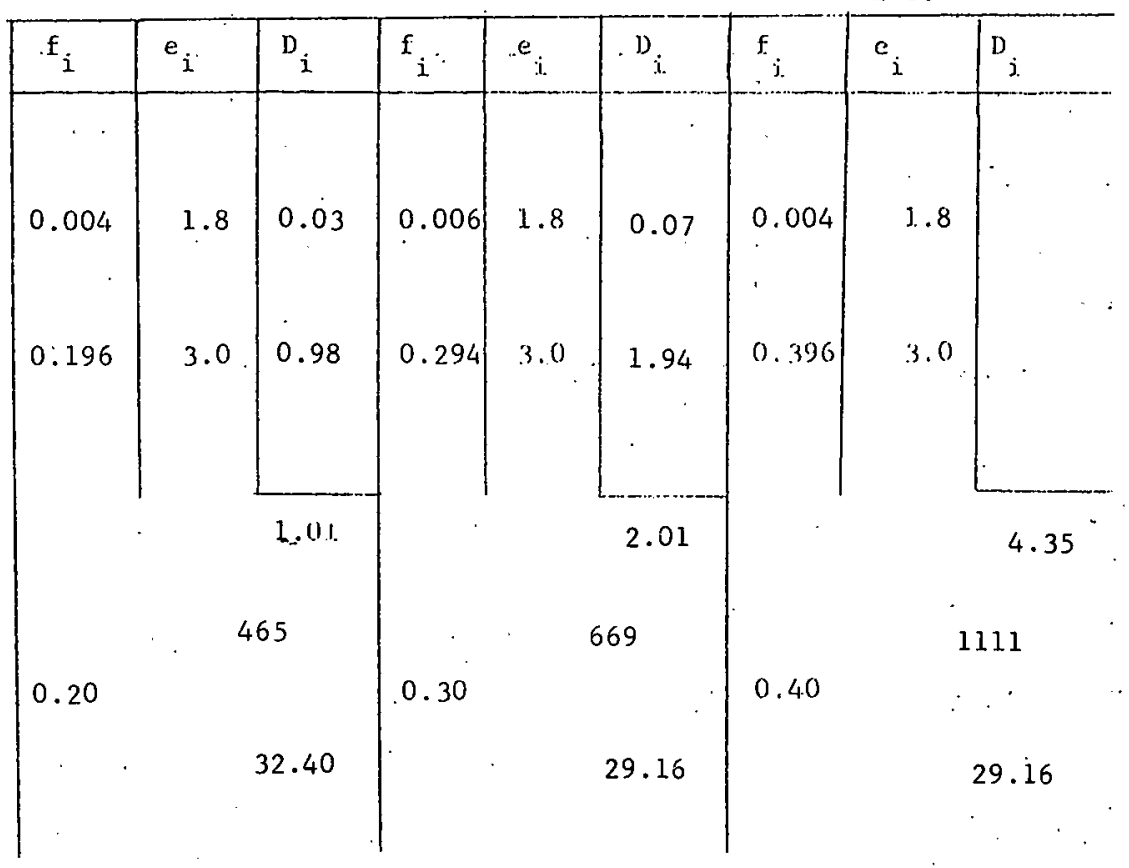

REFERENCE TECHNOLOGIES:

DATA SOURCES:

See Table A-19.

BASIS OF PROJECTIONS: Same as in Table A-21. 
FUEL MIX TABLE

$$
\text { A-24 }
$$

Region: I

Sector: COMMERCIAL

Category: ALL BLILDINGS

End-use: WATER HEATING

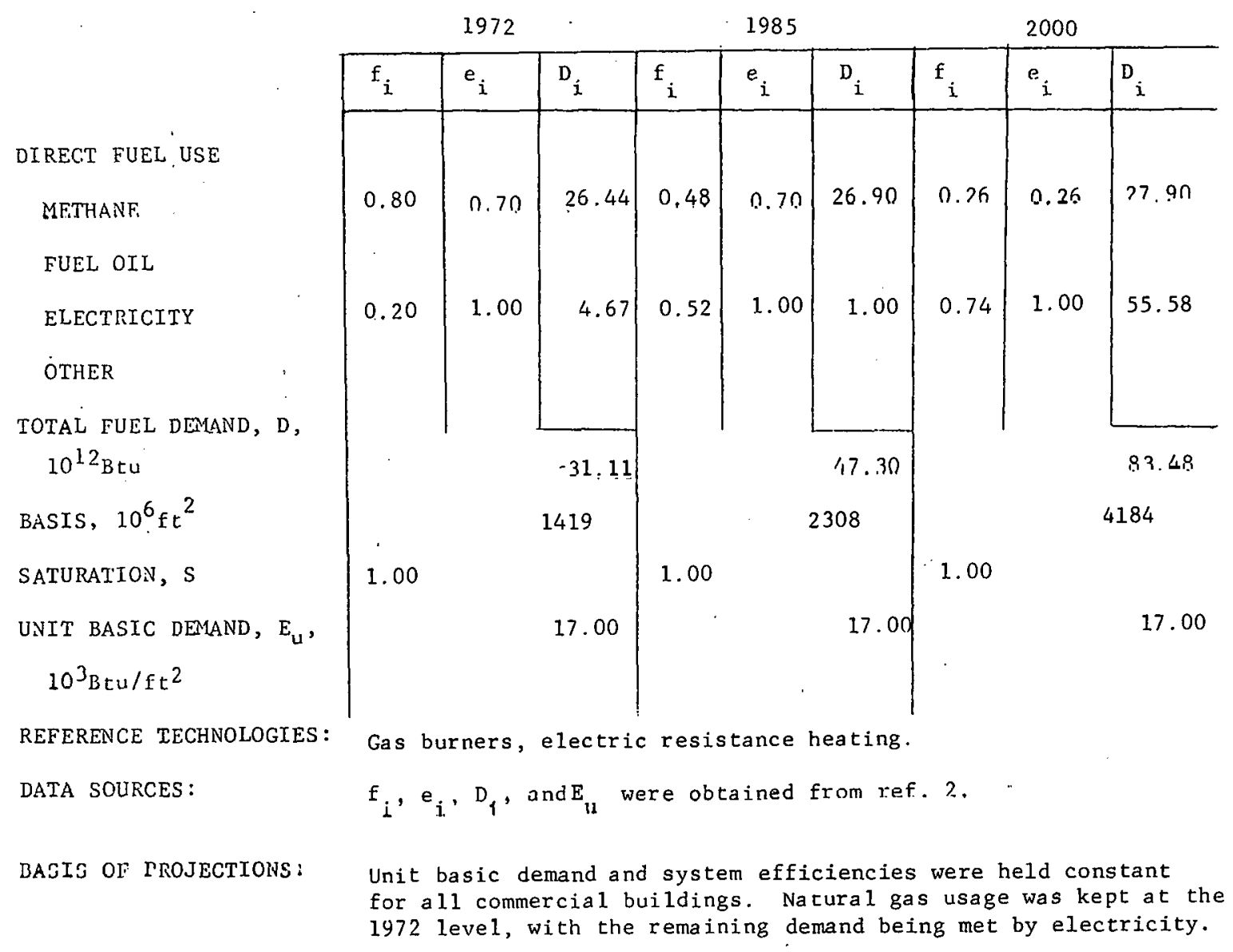


FUEL MIX TABLE

A -25

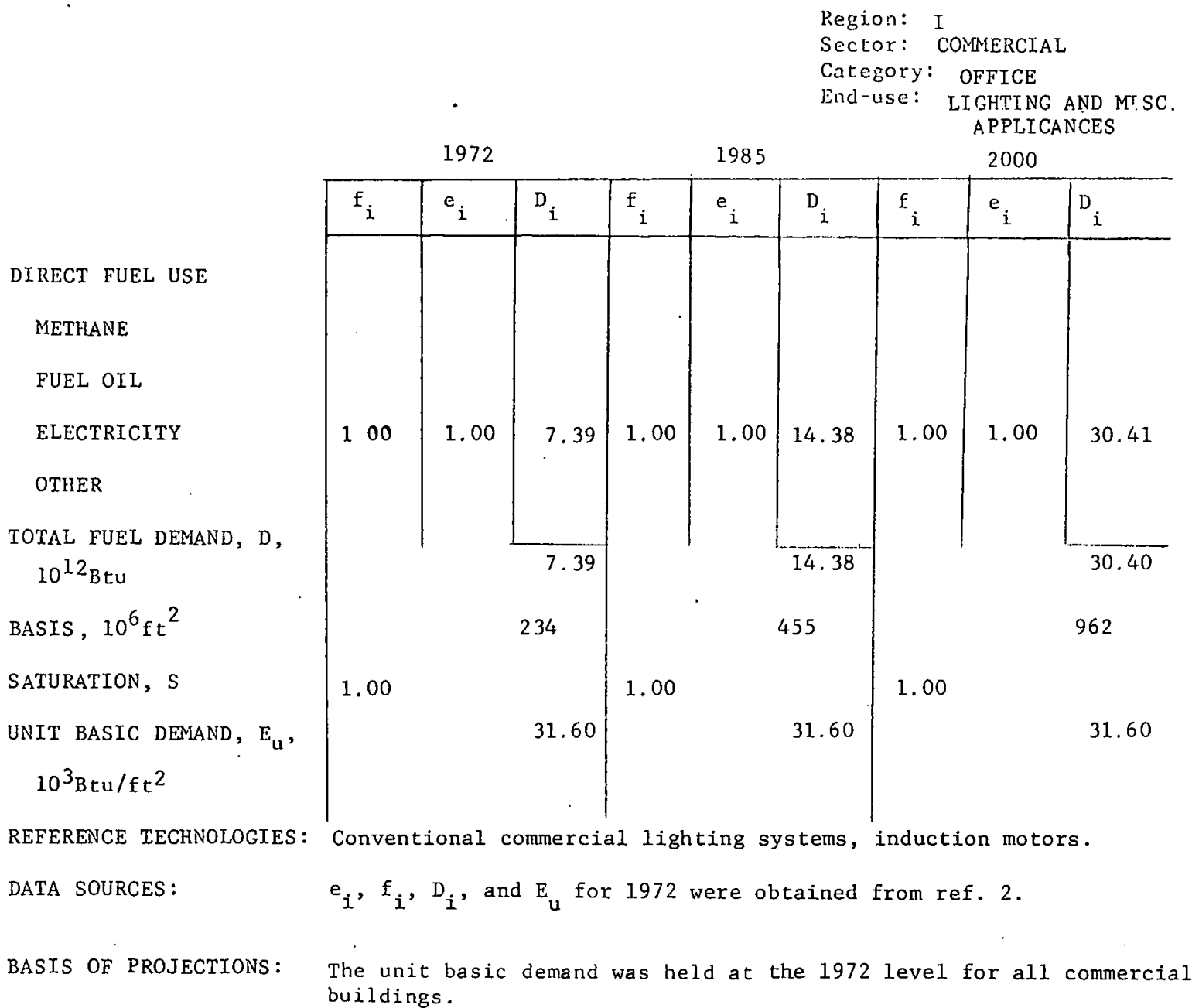


FUEL MIX TABLE

$$
\text { A-26 }
$$

DIRECT FUEL USE

\section{METHANE}

FUEL OIL

ELECTRICITY

OTHER

TOTAL FUEL DEMAND, D, $10^{12} \mathrm{Btu}$

BASIS, $10^{6} \mathrm{ft}^{2}$

SATURATION, S

1972

1985

Region: I

Sector: COINIERCIAL

Category: RETAIL

End-use: J.IGHTING AND MrSC. APPLICANCES

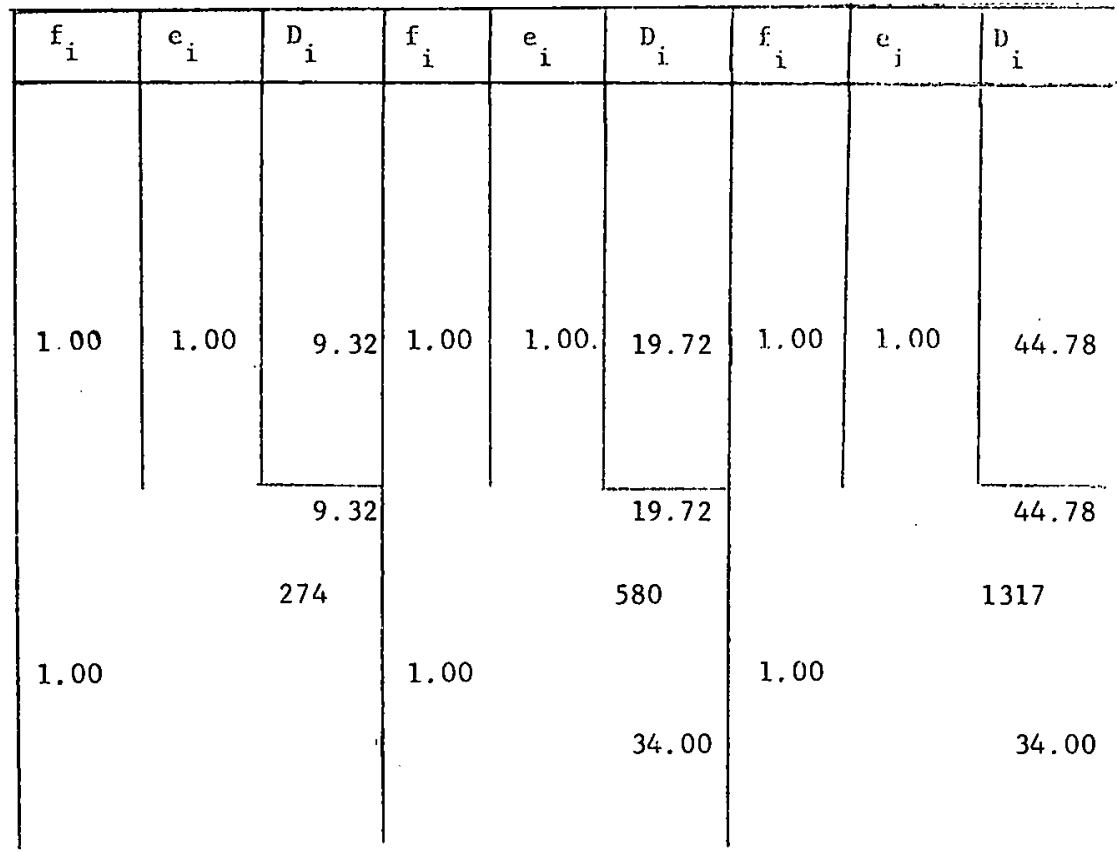

REFERENCE TECIINOLOGIES:

DATA SOURCES:

BASIS OF PRUJECTIONS: For reference technologies, data sources, and basis of prnjertinns, see Table A-25. 
FUEL MIX TABJE

$$
\text { A-27 }
$$

DIRECT FUEL USE

METHANE

FUEL OIJ

ELECTRICITY

OTHER

TOTAL FUEL DEMAND, D, $10^{12} \mathrm{BtC}$

BASIS, $10^{6} \mathrm{ft}^{2}$

SATURATION, S

UNIT BASTC DEMAND, $\mathrm{E}_{\mathrm{u}}$, $10^{3} \mathrm{Btu} / \mathrm{Ft}^{2}$

REFERENCE IECHNOLOGTES:

Region: I

Sector: COMHERCIAL

Category: SCHOOLS

End-use: LIGHTING AND MT.SC. APPLICANCES

1972 1985 2000

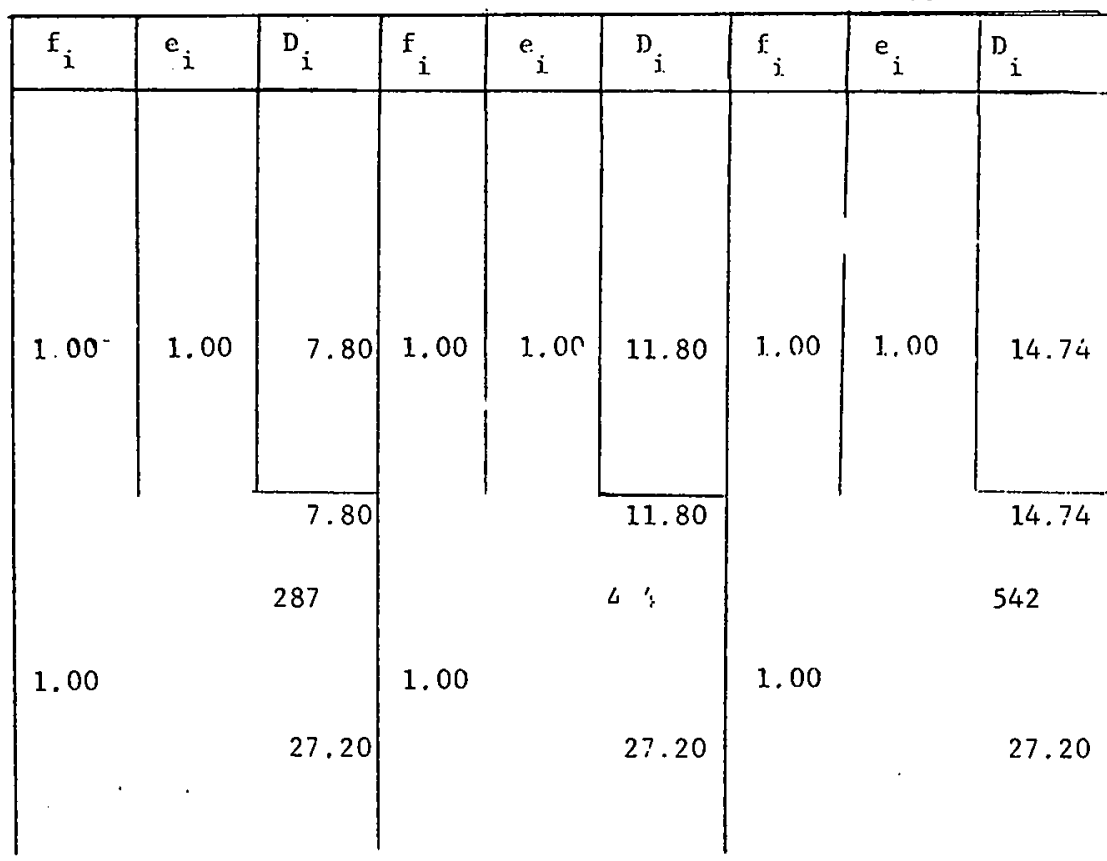

DATA SOURCES :

BASIS OF PROJECTIONS: See Table A-25. 


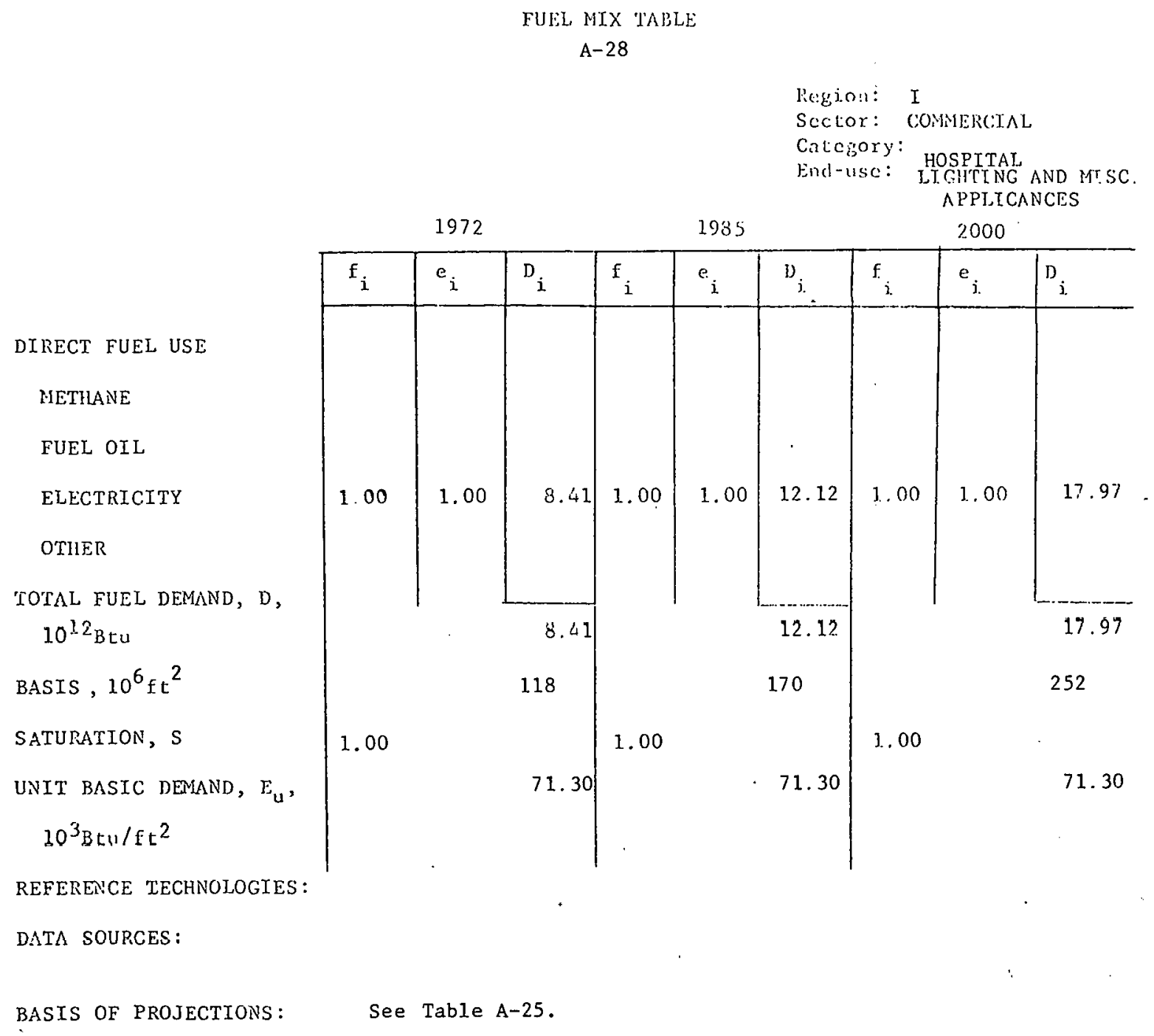


FUEL MIX TABLE

A-29

Region: I

Scclor: COMERCIAL

Category: MISCELLANEOUS

End-uSC: LIGHTING AND MTSC. $\triangle$ PPLICANCES

DIRECT FUEL USE

METHANE

FUEL OIL

ELECTRICITY

OTHER

TOTAL FUEL DEMAND, D, $10^{12} \mathrm{Btu}$

BASIS , $10^{6} \mathrm{ft}^{2}$

SATURATION, S

1972

1985

2000

\begin{tabular}{|c|c|c|c|c|c|c|c|c|}
\hline$f_{i}$ & $e_{i}$ & $D_{i}$ & $\mathrm{f}_{i}$ & $e_{i}$ & $\mathrm{D}_{j}$ & $\mathrm{f}_{\mathrm{i}}$ & ${ }^{e}{ }_{i}$ & $\mathrm{D}_{\mathrm{i}}$ \\
\hline 1.00 & 1.00 & 14.70 & 1.00 & 1.00 & 21.14 & 1.00 & 1.00 & 35.11 \\
\hline & $\cdot$ & $\begin{array}{l}14.70 \\
465\end{array}$ & & & $\begin{array}{l}21.14 \\
659\end{array}$ & & & $\begin{array}{l}35.11 \\
1111\end{array}$ \\
\hline 1.00 & & 31.60 & 1.00 & · & 31.60 & 1.00 & & 31.60 \\
\hline
\end{tabular}

REFERENCE TECHNOLOGIES:

DATA SOURCES:

BASIS OF PROJECTIONS: See Table A-25. 
FUEL MIX TABLE

A- 30
Region: II

Sector: RESIDENTIAL

Cateiry: SINGLE FAMILY DETACHED

End use: SPACE HEATING
DIRECT FUEL USE

METHANE

Existing

Retrofitted

New-improved

New-FHA-MPS

FUEL OIL

Existing

Retrofitted

New - improved

New-FHA - IPS

ELECTRICITY

Existing

New-improved

Heat pump

OTHER

TOTAL FUEL DEMAND, D, $10^{12 \mathrm{Btu}}$

BASIS

103 Houccholdo

SATURATION, S

UNIT BASIC DEMAND, $\mathrm{E}_{\mathrm{u}}$

$10^{6} \mathrm{Btu} /$ household

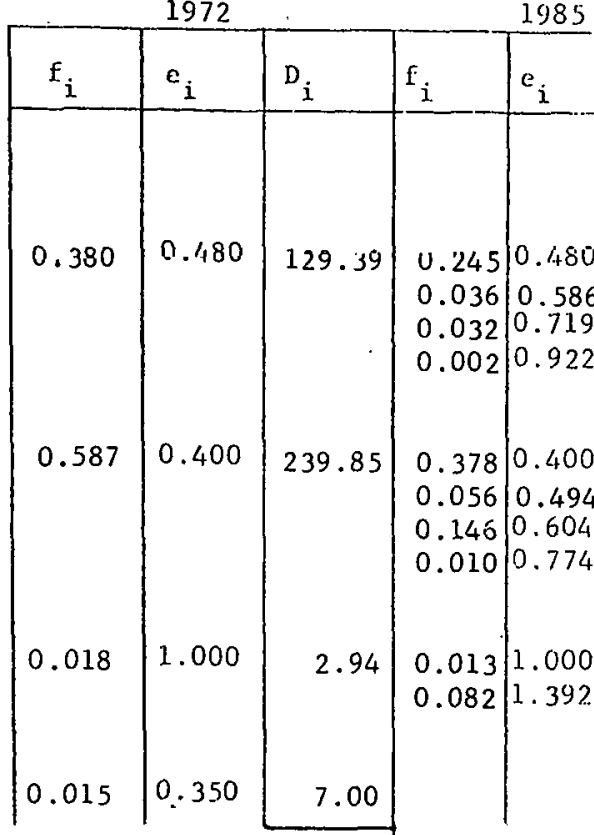

$37 y .18$

2302

1.000

Existing

New
2000

\begin{tabular}{l|l|l|l}
$\mathrm{D}_{i}$ & $\mathrm{f}_{i}$ & $e_{j}$ & $\mathrm{D}_{i}$ \\
\hline
\end{tabular}

- 10.10

92.59

11.14

9.350 .022

\begin{tabular}{l|l}
0.46 & 0.007
\end{tabular}

0.614

\begin{tabular}{l|l}
0.719 & 29.16
\end{tabular}

\begin{tabular}{l|l|l|l}
9.46 & 0.007 & 0.922 & 2.15
\end{tabular}

\begin{tabular}{ll|l|l}
171.42 & 0.232 & 0.440 & 128.98
\end{tabular}

\begin{tabular}{ll|l|l|l}
20.56 & 0.034 & 0.518 & 16.06
\end{tabular}

\begin{tabular}{l|l|l|l}
50.79 & 0.216 & 0.604 & 101.34
\end{tabular}

\begin{tabular}{ll|l|l|l}
2.71 & 0.020 & 0.774 & $7.3 ?$
\end{tabular}

$2.360_{10.008} 1.000$

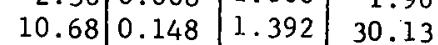

\begin{tabular}{r|r|r|r}
0.088 & 2.800 & 8.91
\end{tabular}

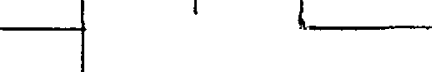

372.06

404.74

2777

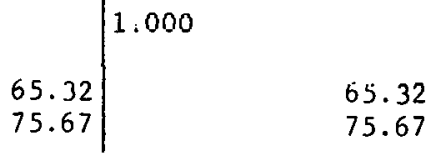

KEFERENCE TECHNOLOGIES:

DA.TA SOURSES :

BASIS OF YROJECTIONS:

Note: For all Region TT· tahles for tho reoidential sillu, bu currcoponding Region I tables for reference technologies, data sources and basts of projection. 


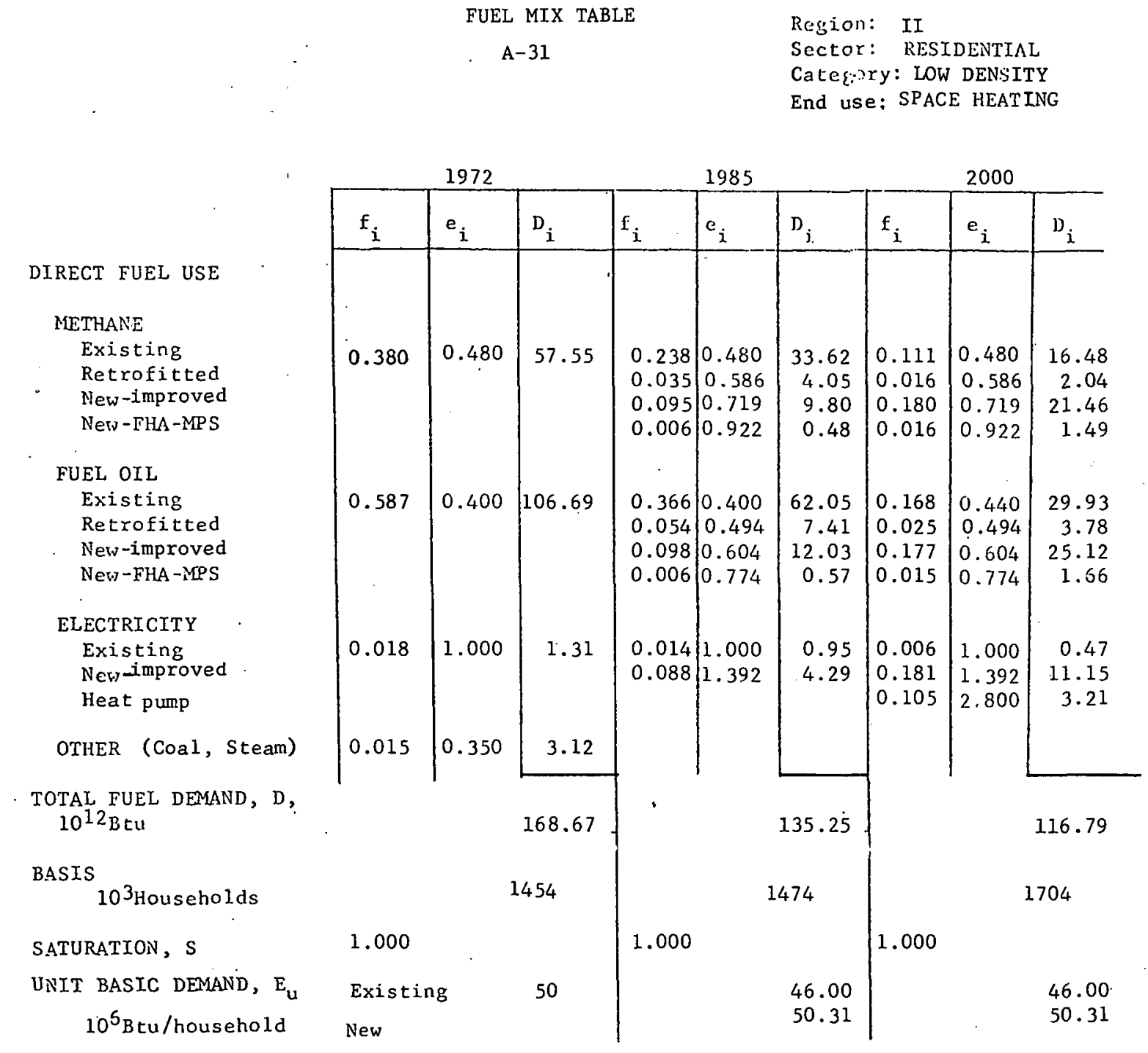

RFFERENCE TECHNOLOGIES:

DATA SOUREES:

BASIS OF PROJECTION: 
FUEL MIX TABLE

A-32
Region: II

Sector: RESIDENTIAL

Cateriry: LOW RISE

End use : SPACE HEATING
DIRECT FUEL USE

Methane

Existing

Retrofitted

New-i mproved

New - FHA - NPS

FUEL OIL

Existing

Retrofitted

New-improved

New-FHA-MPS

ELECTRICITY

Existing

New-imp roved

Heat pump

OTHER (Coal, Steam)

TOTAL FUEL DEMAND, D, $1012 \mathrm{Btu}$

BASIS

$10^{3}$ Households

SATURATION, S

1.000

UNIT BASIC DEMAND, $E_{u}$ $10^{6} \mathrm{Btu} /$ household

REFERENCE TECHNOLOGIES :

DATA SOUREES :

BASIS OF PROJECTION:

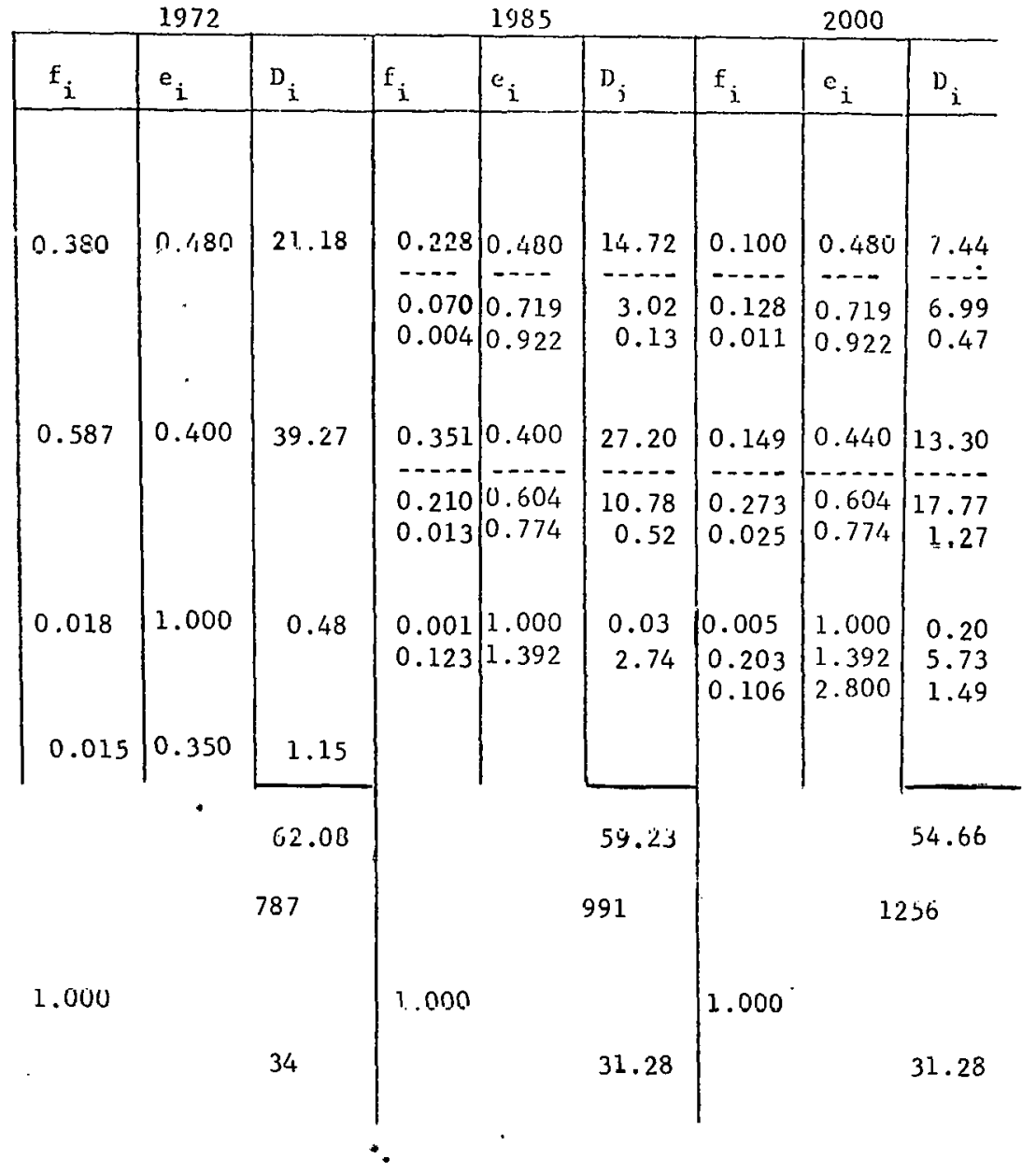




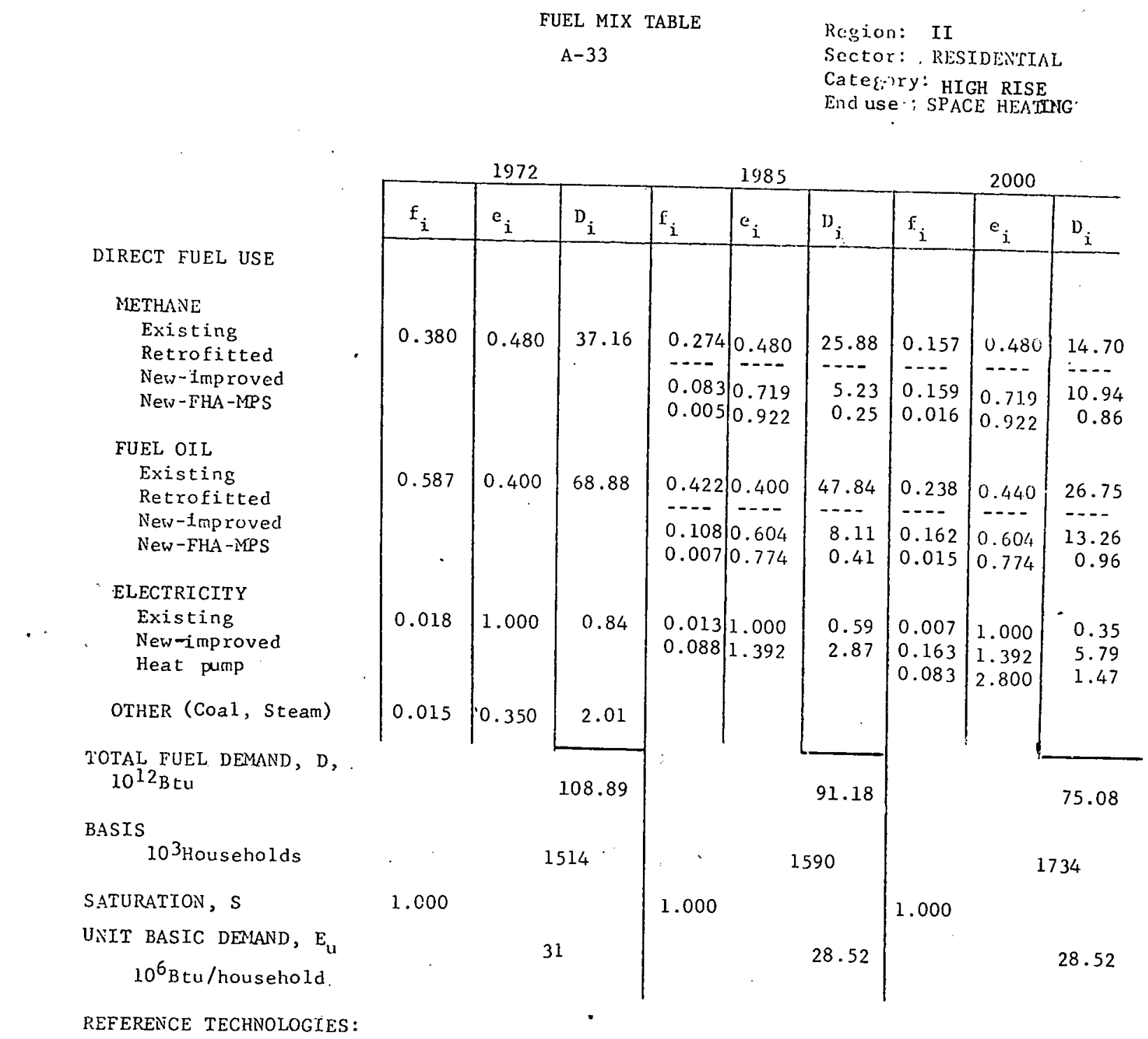

DATA SOURCES:

BASIS OF PROJECTION: 
FUEL MIX TABLE

$$
\text { A-34 }
$$

Region: II

Sector: RESIDENTIAL

Category:MOBILE HOME

End-use: SPACE HEATING

DIRECT FUEL USE

METHANE

Existing

Retrofitted

New -1 mp roved

New-FHA-MPS

FUEI. OIL

Existing

Retrofitted

New-improved

New-FHA -MPS

ELECTRICITY

Existing

New-improved

Heat pump

กTHER.

TOTAL FUEL DEMAND, D, 1.0 $12 \mathrm{~B}+.$,

BASIS

10 Illousélıúlds

SA'IURATION, S

UNIT BASIC DEMAND, $\mathbf{E}_{\mathbf{u}}$

( $10^{6} \mathrm{Btu} /$ household)

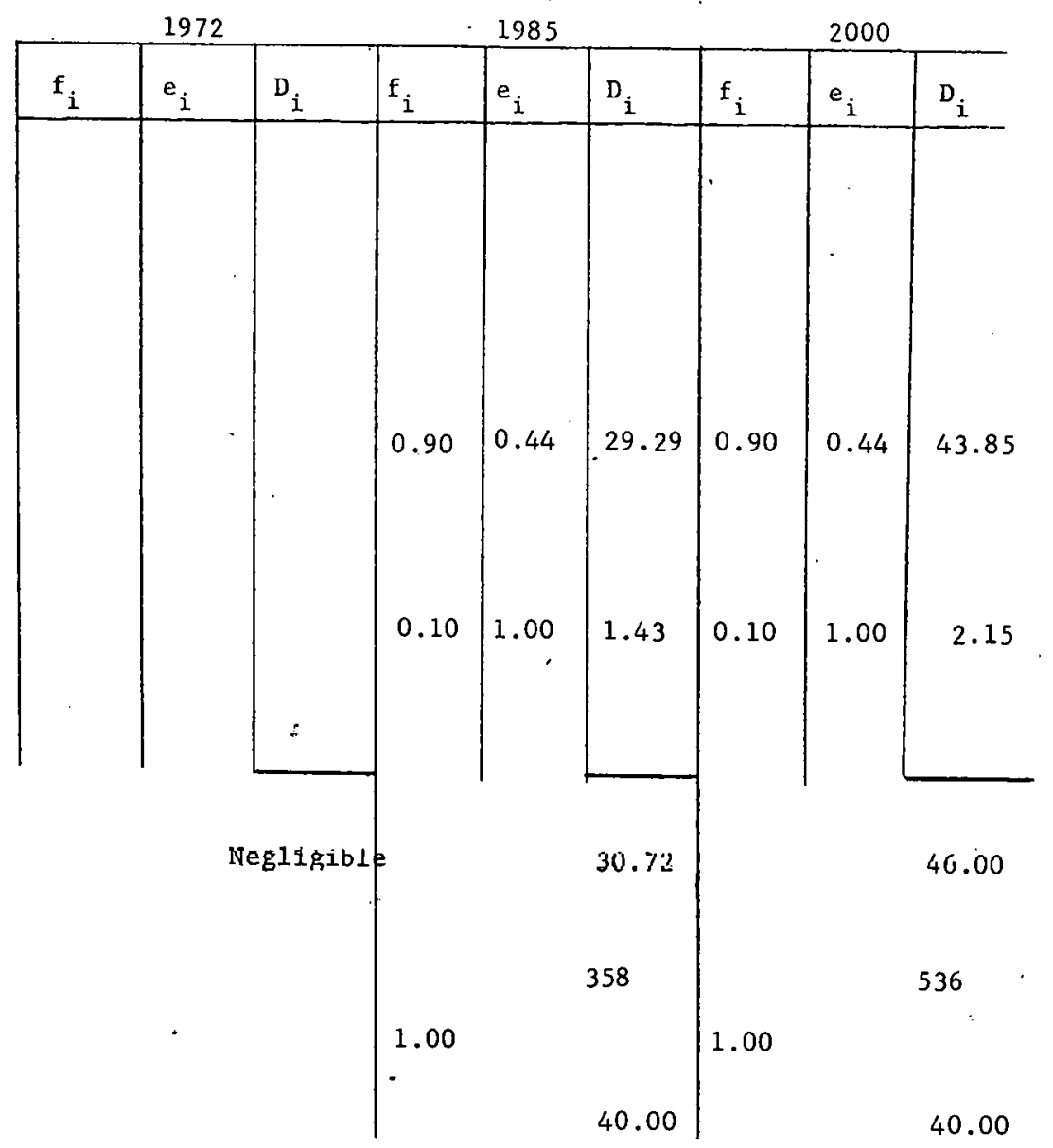

REFERENCE TECHNOLOGIES:

DATA SOURCES:

BASIS OF PROJECTION: 


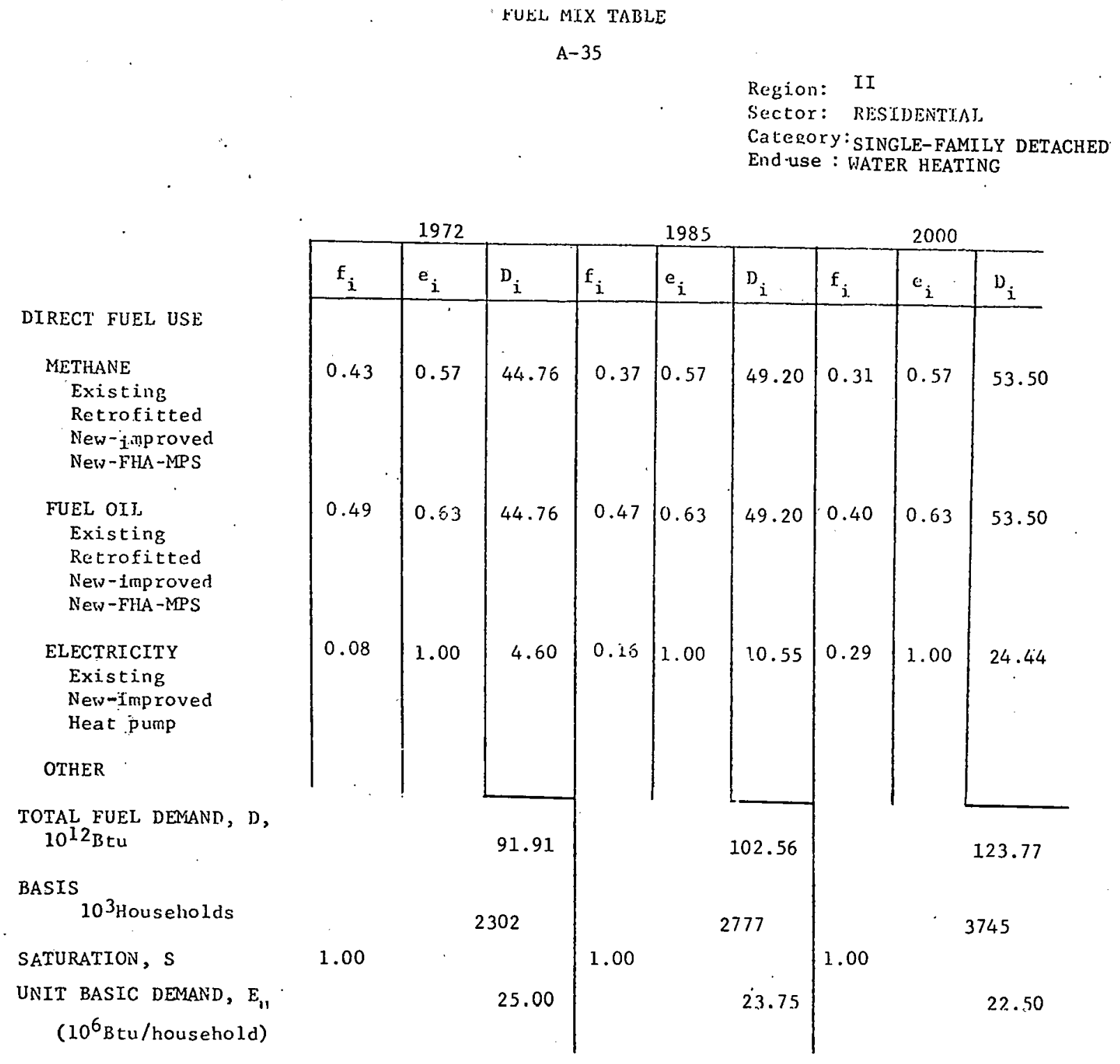

REFERENCE TECHNOLOGIES:

DATA SOURCES:

BASIS OF PROJECTION: 
VUEL MIX TABLE

$$
\text { A-36 }
$$

Region: II

Sector: RESTDENTIAI.

Category: LOW DENSITY

End-use : WATER HEATING

DIRECT FUEL USE

\section{METHANE}

Existing

Retrofitted

New-improved

New-FHL-MPS

FUEL OIJ,

Existing

Retrofitted

New-Inproved

New-FHA-PPS

ELECTRICITY

Existing

New-improved

Hcat pump

OTHER

TOTAL FUFI. DEMAND, D, $10^{12}$ ELU

BASIS

$10^{3}$ Households

SATURATION, $S$

UNIT BASIC DEMAND, $\mathrm{E}_{\mathrm{u}}$

( $10^{6}$ Btu/household)

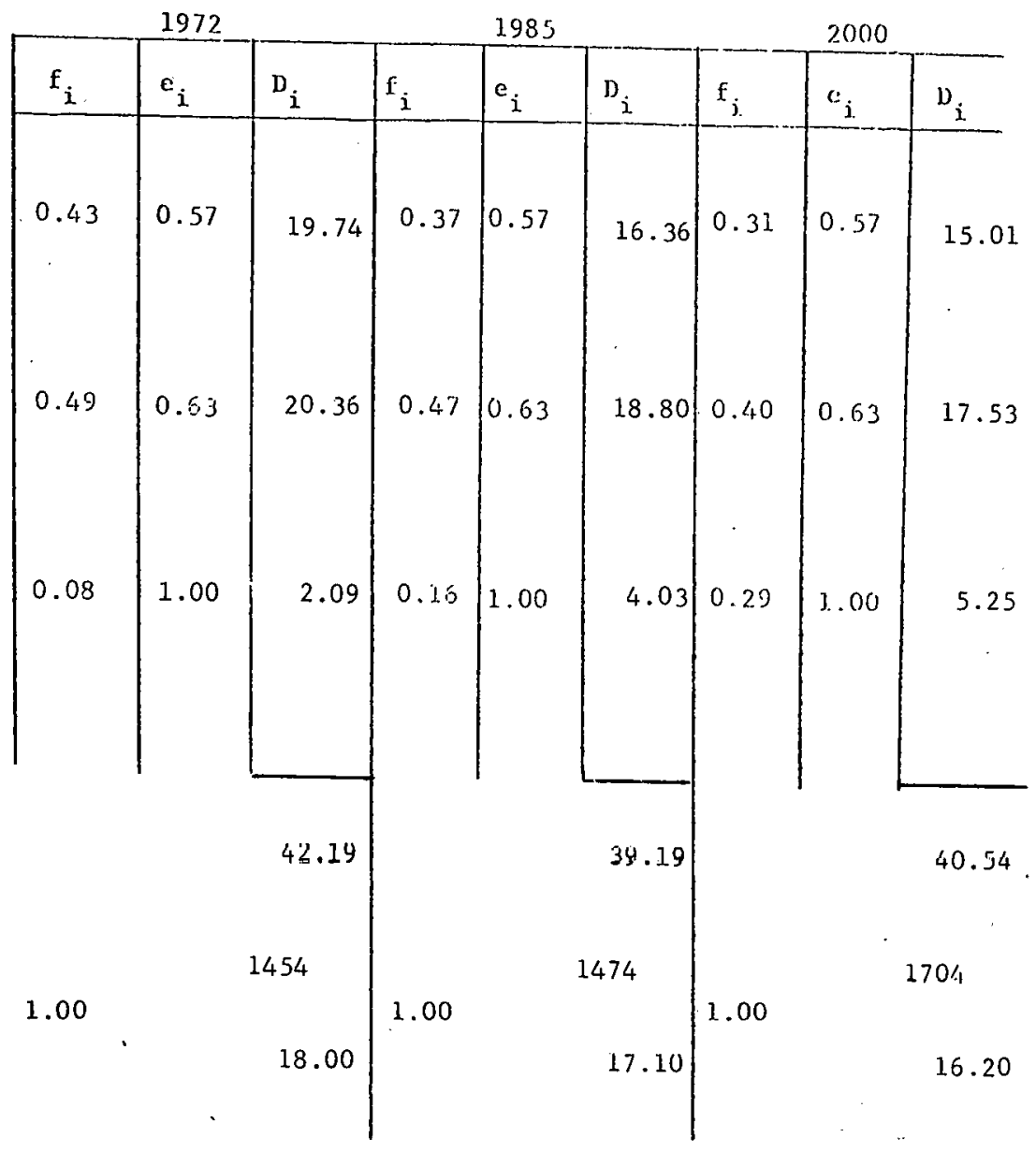

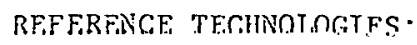

DATA SOURCES:

PAGTS OF PROTECTTON: 


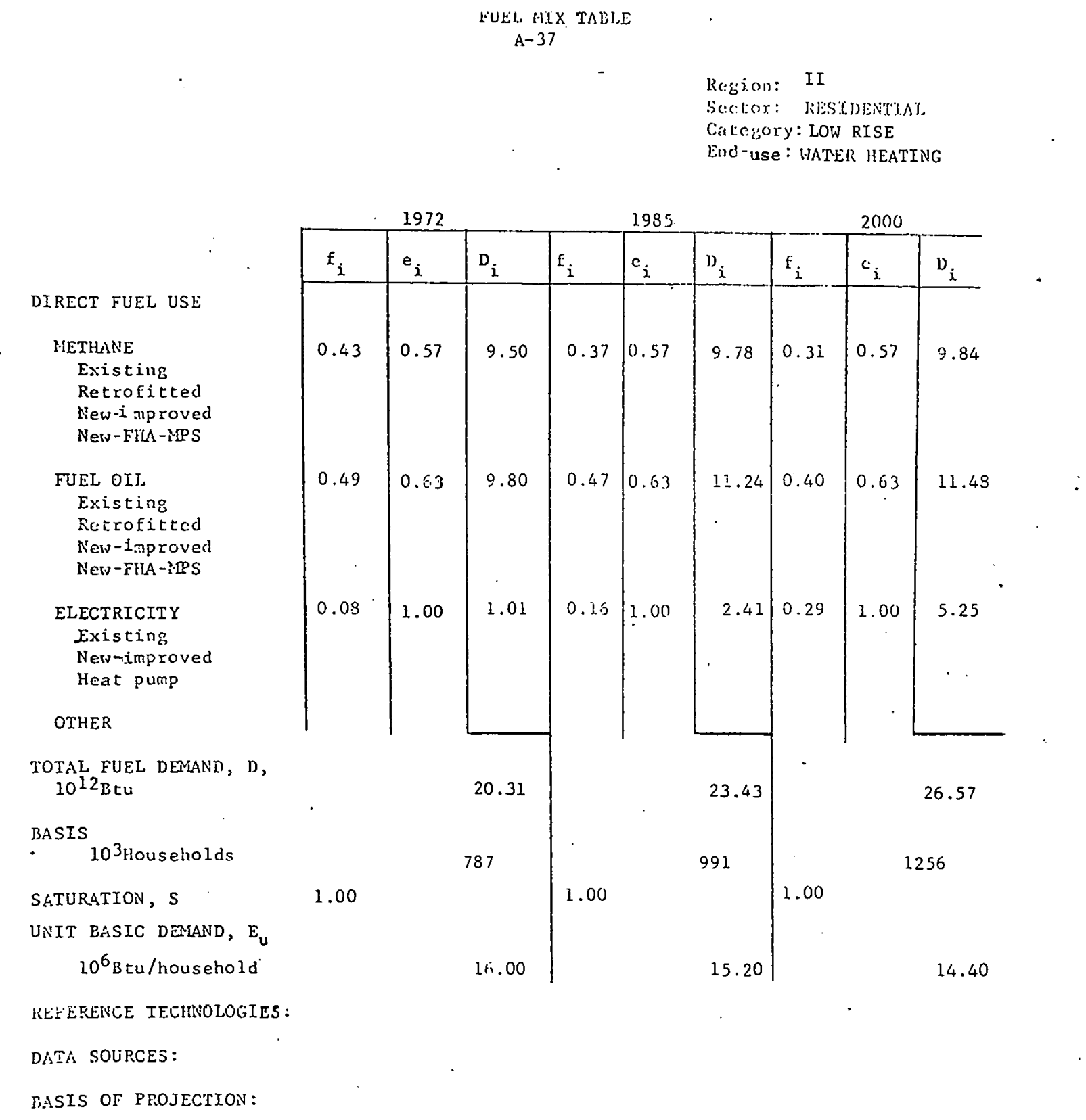




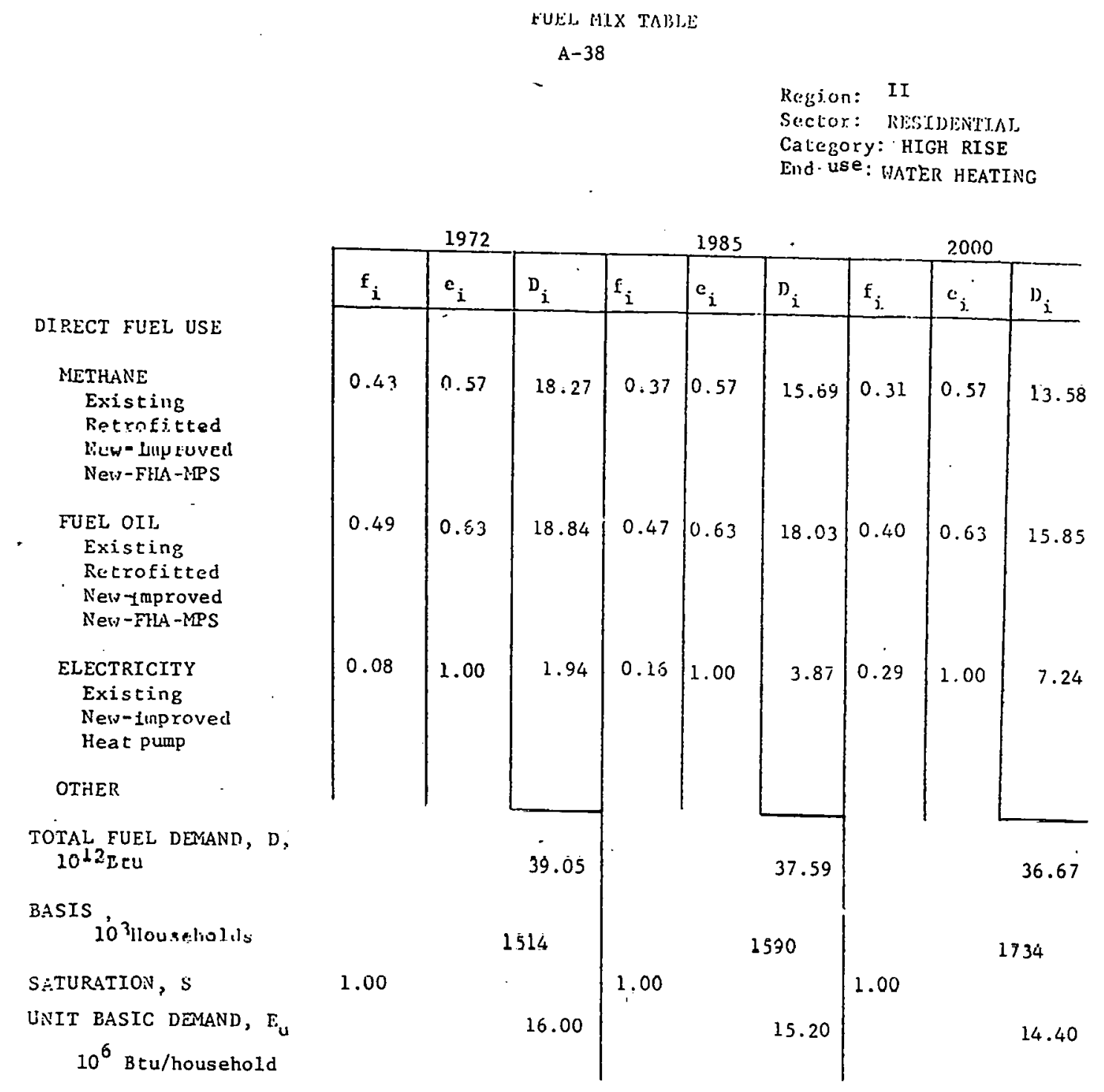

REFERENCE TECHNOLOGIES:

DATA SOURCES:

DAJI3 OT PROJLCTION : 
FUEL MIX TABLE

A -39

Region: II

Sector: RESIDENTIAL

Category: MOBILE HOME

End-use : WATER HEATING

DIRECT FUEL USE

METHANE

Existing

Retrofitted

New-improved

New-FHA-MPS

FUEL OIL

Existing

Retrofitted

New-improved

New-FHA-MPS

ELECTRICITY

Existing

New-Improved

Heat Pump

OTHER

TOTAL FUEL DEMAND, D', $10^{12} \mathrm{Btu}$

BASIS

$10^{3}$ Households

SATURATION, S

UNIT BASIC DEMAND, $\mathrm{E}_{\mathrm{u}}$

$.10^{6} \mathrm{Btu} /$ household

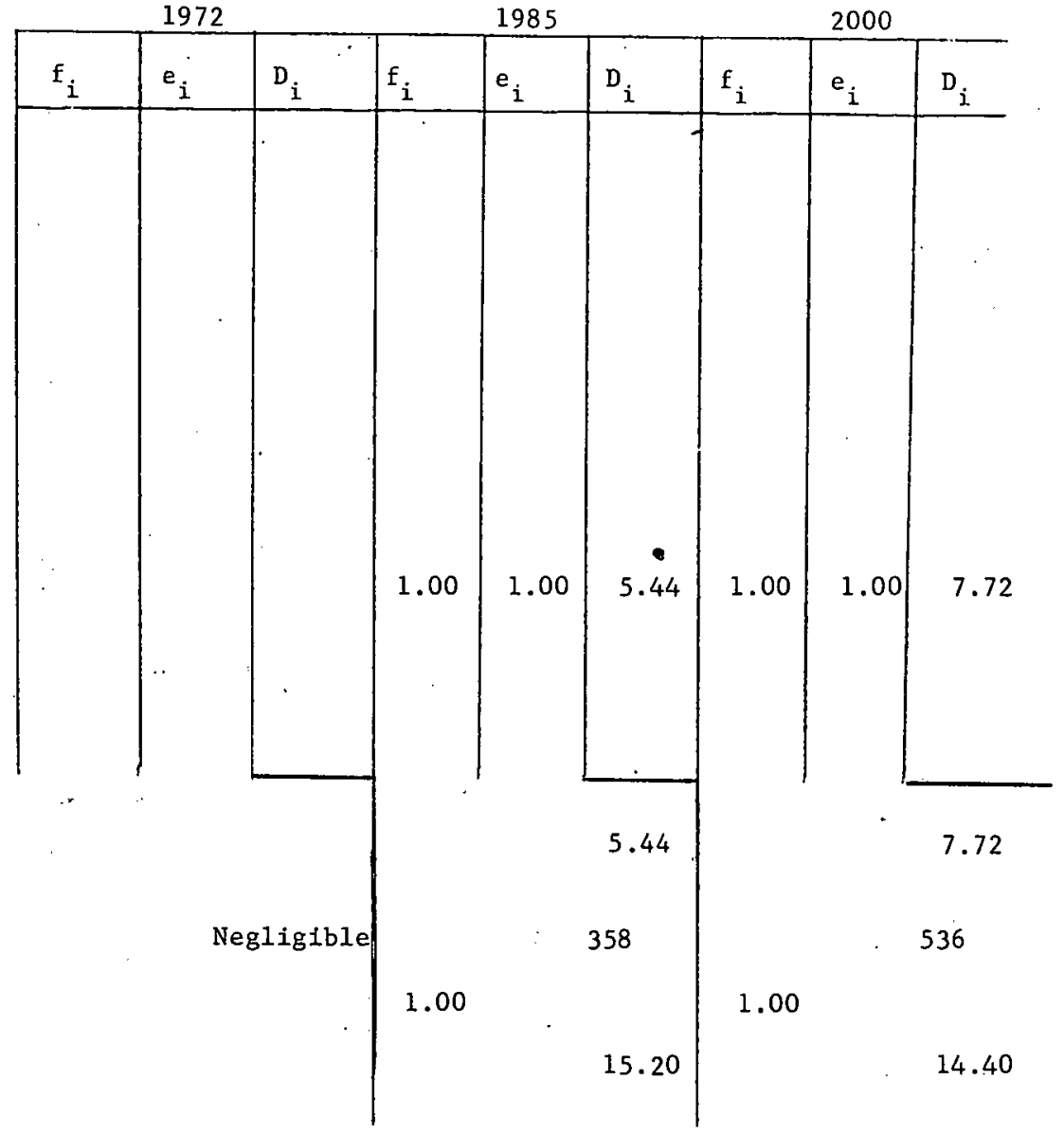

REFERENCE TECHNOLOGIES :

DATA SOURCES:

BASIS OF PROJECTICN: 


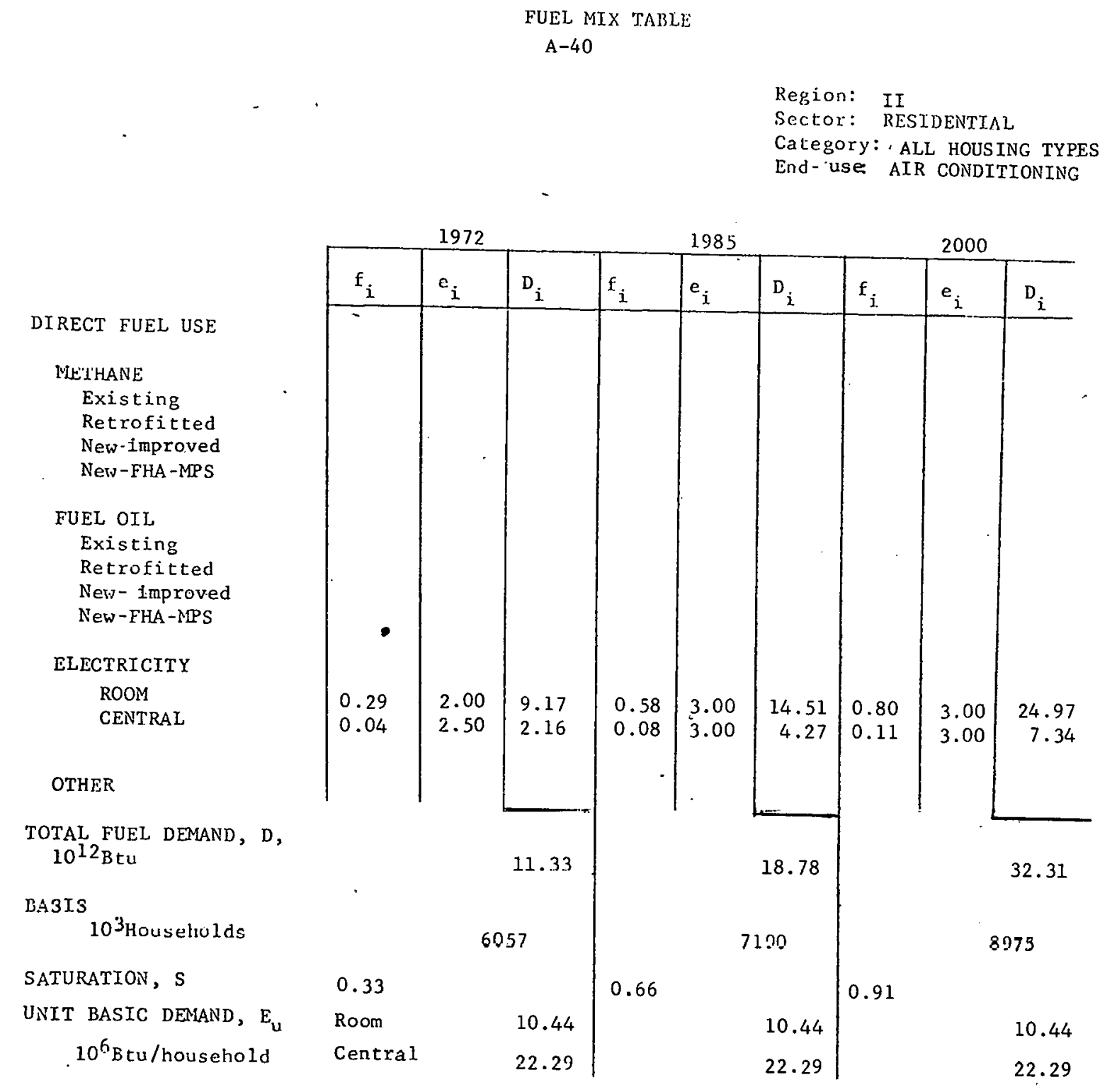

REFERENCE TECHNOLOGIES:

DATA SOURCES:

RASTS OF PROTECTION: 
FUEL MIX TALLE

A-41

Region: II

Scctor: RESTJENITAL

Category: ALL HOUSING TYPES

End use : COOKING

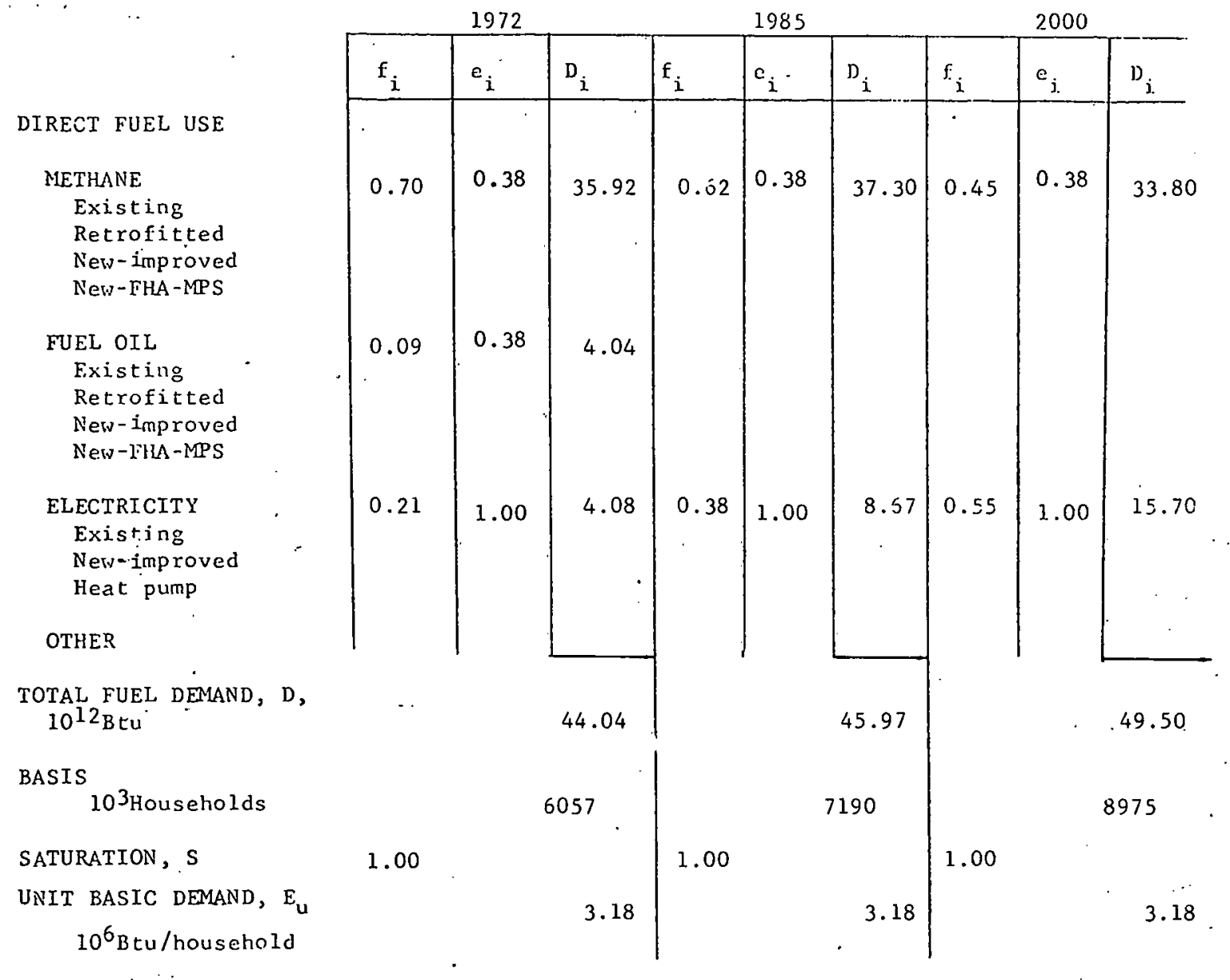

REFERENCE TECHNOLOGLES:

DATA SOURCES:

BASIS OF PROJECTION: 
FUEL MCX TABLE

A-42

Region: II

Sector: RESIDENTIAL

Cateroly: ALL HOUSING TYPES

Find use : LIGHTING \& MISC.

ELECTRIC APPLIANCES

DIRECT FUEL USE

METHANE

Existing

Retrofitted

New-improved

New-FH: -MPS

FUEL OIL

Existing

Retrofitted

New-improved

New-FHA-NPS

ELECTRICITY

Existing

New-improved

Heat pump

OTHER

TOTAL FUEL DENAND, D, $10^{12} \mathrm{Btu}$

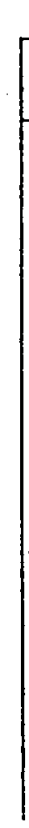

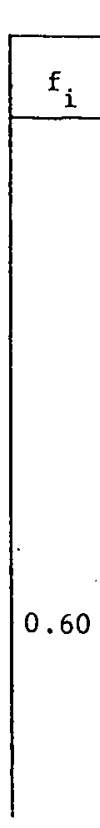

1972

1985

2000

\begin{tabular}{l|l|l|l}
$e_{i}$ & $D_{i}$ & $f_{i}$ & $e_{i}$ \\
\hline
\end{tabular}

\begin{tabular}{|l|l|l|l|}
\hline$D_{i}$ & $f_{i}$ & $e_{i}$ & $D_{i}$ \\
\hline
\end{tabular}

BASIS

$10^{3}$ Hunscliulda

SATURATION, $S$

0.60

UNIT BASIC DEMAND, $\mathrm{E}_{u}$

$10^{6} \mathrm{Btu} /$ household

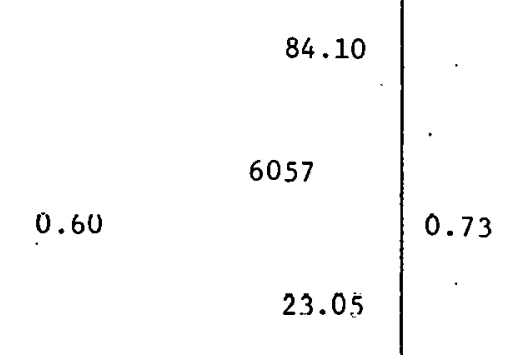

112.32

166.65

7190

\begin{tabular}{l|l|l|l}
112.32 & 0.88 & 1.00 & 166.65
\end{tabular}

REFERENCE TECHNOLOGIES:

DATA SOURCES:

BASIS OF PROJECTION: 
FUEI, HIX ThEISE

A-43

Reijion: II

Sectox: COMMERCIAL

Catcegory: OFFICE

find-use: SPACE HEATING

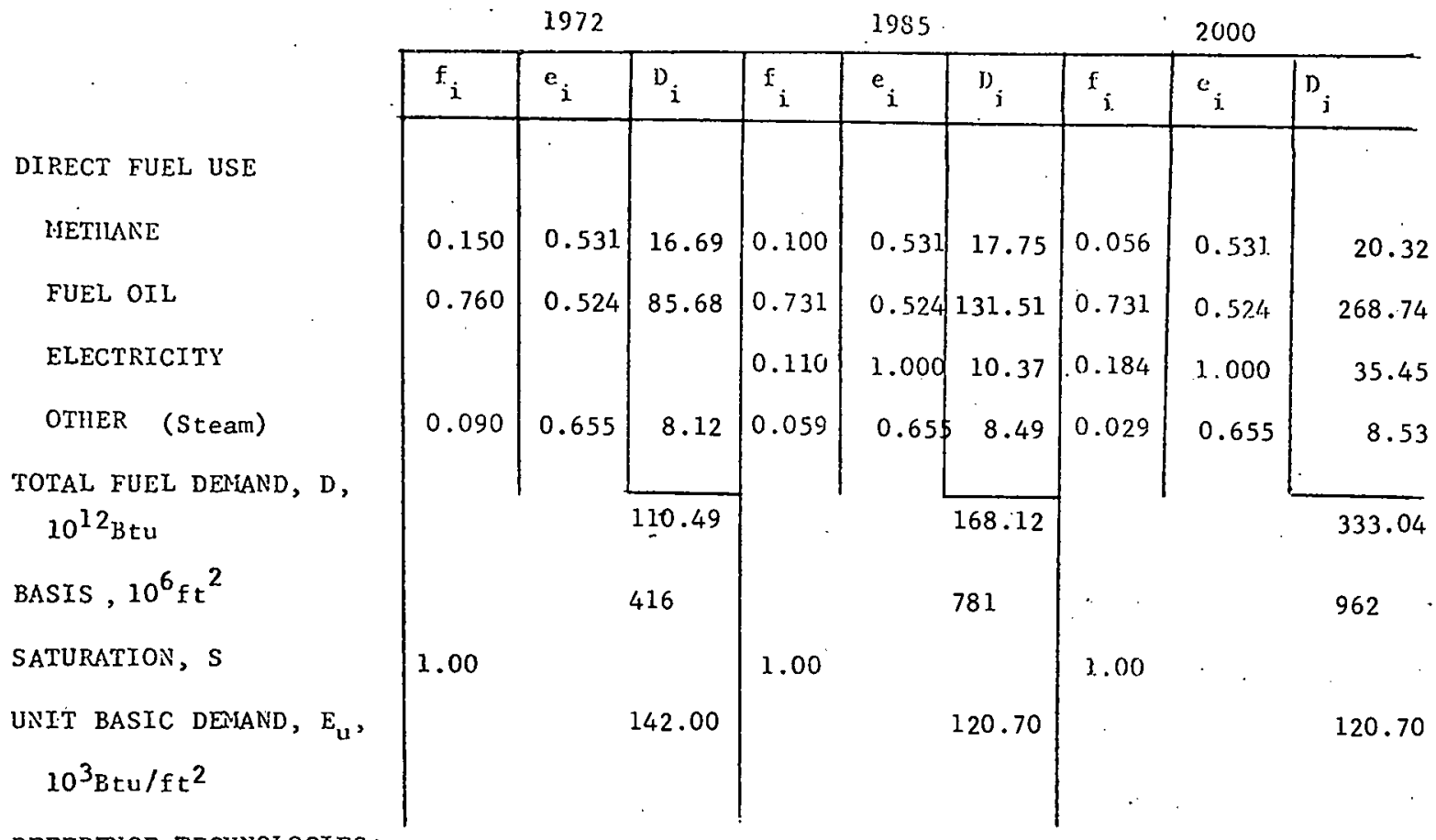

REFERENCE TECHNOLOGIES:

DATA SOURCES:

BASIS OF PROJECTIONS:

Note: For all Region II tables for the commercial sector, see corresponding Region I tables for reference technologies, data sources, and basis of projection. 
FUEL HIX: T/BLE

$\therefore \quad$ A-44

Re;ion: II .

Sector: CONMERCIAJ

Calloory: RETAIL

End-USC: SFACE HEATING

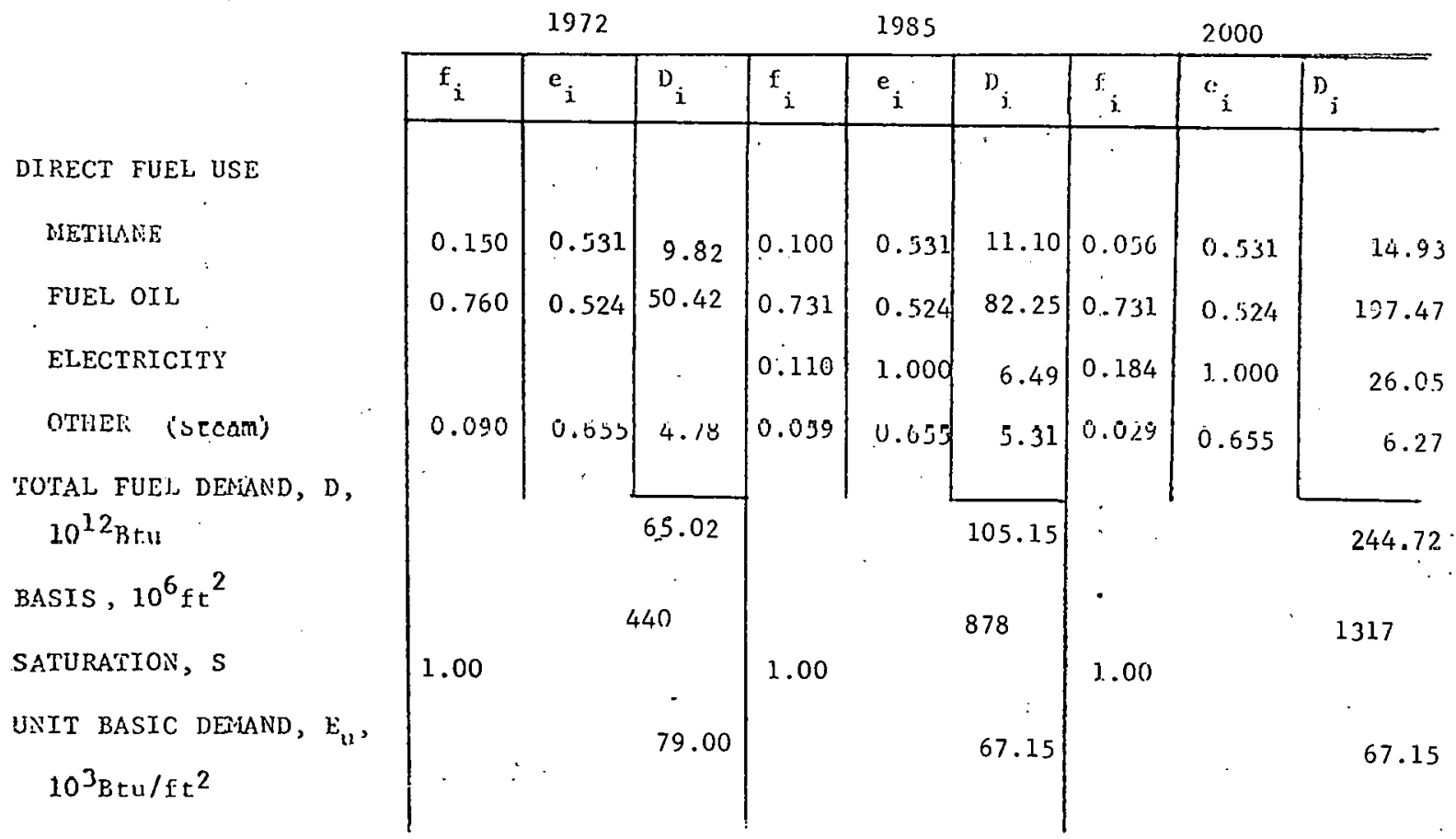

REFERENCE TECHNOLOGIES:

DATA SOIRCES:

BASIS OF PROJECTIONS: 
FUEL WLX TABIE

A-45

Region: II

Sector: COHNERCIAL

Catcegory: SCHOOL

Find-usc: SEACE HEATING

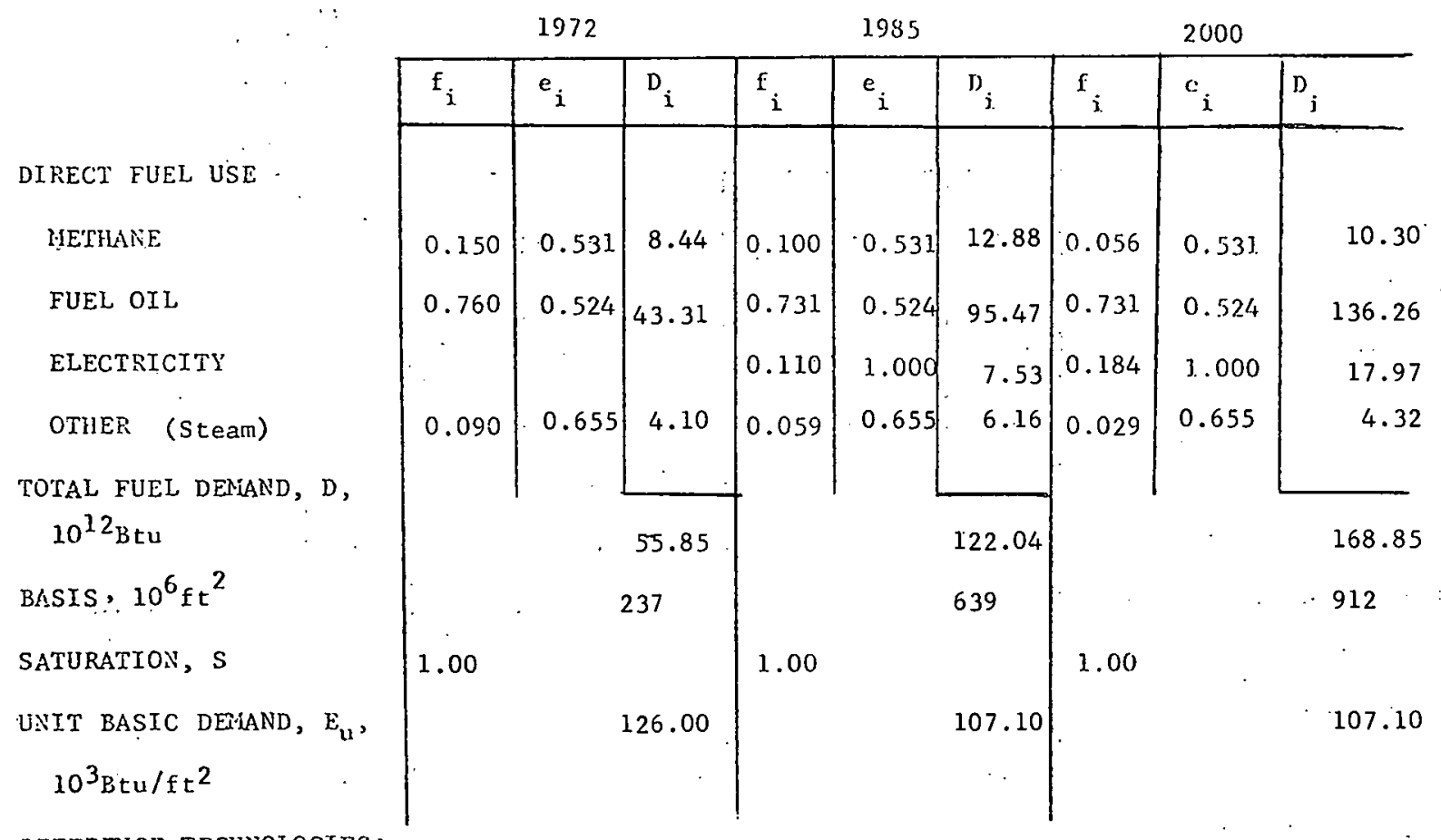

REFERENCE TECHNOLOGIES:

DÁTA SOURCES:

BASIS OF PROJECTIONS: 
FUEL HIX TABLF:

$$
\text { A-46 }
$$

Reigion: II

Sector: CONMERCIAL

Cistegrory: HOSPITAL

End-usc: SPACE HEATING

\begin{tabular}{|c|c|c|c|c|c|c|c|c|c|}
\hline & \multicolumn{3}{|c|}{1972} & \multicolumn{3}{|c|}{1985} & \multicolumn{3}{|c|}{2000} \\
\hline & $f_{i}$ & $e_{i}$ & $\mathrm{D}_{i}$ & $\mathrm{f}_{\mathbf{i}}$ & $e_{i}$ & ${ }_{j}{ }_{j}$ & $\mathrm{f}_{\mathrm{j}}$ & ${ }^{c}{ }_{j}$ & $\mathrm{D}_{i}$ \\
\hline DIRECT FUEL USE & & & & & & & & & \\
\hline METHANE & 0.150 & 0.531 & 8.46 & 0.100 & 0.531 & 6.62 & 0.056 & 0.531. & \\
\hline FUEL OIL & 0.760 & 0.524 & 43.43 & 0.731 & 0.524 & 49.02 & 0.731 & 0.524 & 70.47 \\
\hline ELECTRICITY & & & & 0.110 & 1.000 & 3.87 & 0.184 & 1.000 & 9.30 \\
\hline OTHER (Steam) & 0.090 & 0.655 & 4.11 & 0.059 & 0.655 & $\cdot 3.17$ & 0.029 & 0.655 & 2.24 \\
\hline $\begin{array}{l}\text { TOTAL FUEL DEMIAND, D, } \\
10^{12} \mathrm{BEU}\end{array}$ & & & 56.00 & & & 62.68 & & & 87.34 \\
\hline BASIS, $10^{6} \mathrm{ft}^{2}$ & & & 197 & & & 272 & & & 391 \\
\hline SATURATION, S & 1.00 & & & 1.00 & & & 1.00 & & \\
\hline $\begin{array}{l}\text { UNIT BASIC DEMAND, } \mathrm{E}_{\mathrm{u}} \text {, } \\
10^{3} \mathrm{DLu} / \mathrm{ft} \mathrm{t}^{?}\end{array}$ & & & 152.00 & & & 129.20 & & & $129: 20$ \\
\hline
\end{tabular}

REFERENCE TECHNOLOGIES:

DATA SNIRCES:

BASIS OF PROJECTIONS: 
FUEL $M T X . T \wedge \mathrm{BI} . \mathrm{E}$

$$
\text { A-47. }
$$

Reijion: II

Sector: CONMERCIAL

Catcgory: MISCELLANEOUS

End-use: SPACE HEATING

DIRECT FUEL USE

METHANE
FUEL OIL
ELECTRICITY
OTHER (StEam)
TOTAL FUEL DEMLAND, D,
$10^{12_{\text {BtU }}}$

BASIS $10^{6} \mathrm{ft}^{2}$

SATURATION, S

1972

1985

000

\begin{tabular}{|c|c|c|c|c|c|c|c|c|}
\hline$f_{i}$ & $e_{i}$ & $\mathrm{D}_{\mathbf{i}}$ & $\mathrm{f}_{i}$ & $e_{i}$ & ${ }{ }_{i}$ & $\mathbf{f}_{\mathbf{j}}$ & ${ }^{e}{ }_{i}$ & $D_{i}$ \\
\hline . & & & & & & & & , \\
\hline 0.150 & 0.531 & 15.73 & 0.100 & 0.531 & 12.75 & 0.056 & 0.531 & 11.74 \\
\hline 0.760 & 0.524 & 80.78 & 0.731 & 0.524 & 94.43 & 0.731 & 0.524 & .155 .22 \\
\hline & . & & 0.110 & 1.000 & 7.45 & 0.184 & 1.000 & 20.47 \\
\hline 0.090 & 0.655 & 7.65 & 0.059 & 0.655 & 6.10 & 0.029 & 0.655 & 6.63 \\
\hline & & 104.16 & & & 120.73 & & & 194.06 \\
\hline & & 705 & & & 1008 & & & 1657 \\
\hline 1.00 & & r & 1.00 & & & 1.00 & & \\
\hline ' & & 79.00 & $\therefore$ & & 67.15 & & & 67.15 \\
\hline
\end{tabular}

REFERENCE IECHNOLOGIES:

DATA SOURCES:

BASIS OF PROJECTIONS: 
FUEL MIX TABLE

A-48

Region: II

Sector: COMMERCIAL

Category: OFFICE

End-use: AIR CONDITIONING

\begin{tabular}{|c|c|c|c|c|c|c|c|c|c|}
\hline & \multicolumn{3}{|c|}{1972} & \multicolumn{3}{|c|}{198.5} & \multicolumn{3}{|c|}{2000} \\
\hline 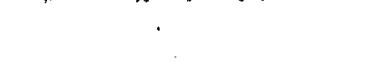 & $\mathrm{f}_{i}$ & $e_{i}$ & $\mathrm{D}_{\mathrm{i}}$ & $\mathrm{f}_{\mathrm{i}}$ & $e_{i}$ & $D_{i}$ & $\mathrm{f}_{\mathrm{i}}$ & $e_{i}$ & $D_{i}$ \\
\hline DIRECT FUEL USE & & & $i$ & & & & & & \\
\hline METHANE & 0.036 & 1.8. & 0.30 & 0.02 & 1.8 & 0.29 & 0.01 & 1.8 & 0.29 \\
\hline FUEL OIL & . & & & & & & & & \\
\hline ELECTRICITY & 0.964 & 3.0 & 4.89 & 0.98 & 3.0 & .8 .40 & 0.99 & 3.0 & 17.35 \\
\hline OTHER & & & & & & & & & \\
\hline TOTAL FUEL DEMAND, D, & & & & & & & & & \\
\hline $10^{12} \mathrm{Bcu}$ & & & 5.19 & . & & 8.69 & & & 1.7 .84 \\
\hline BASIS $10^{6} \mathrm{ft}^{2}$ & . & 416 & & & 781 & & & 1596 & \\
\hline SATURATION, S & 1.00 & & & 1.00 & & & 1.00 & & \\
\hline $\begin{array}{l}\text { UNIT BASIC DEMAND, } \mathrm{E}_{\mathrm{u}} \text {, } \\
10^{3} \mathrm{Btu} / \mathrm{ft}^{2}\end{array}$ & . & & 36.60 & & & 32.94 & & & 32.94 \\
\hline
\end{tabular}

REFERENCE TECHNOLOGIES :

DATA SOURCES;

BASIS OF PROJECTIONS: 
FUEL MIX TABLE

$$
\text { A-49 }
$$

Region: II

Sector: COMMERCIAL .

Category: RETAIL

End-use: AIR CONDITIONING

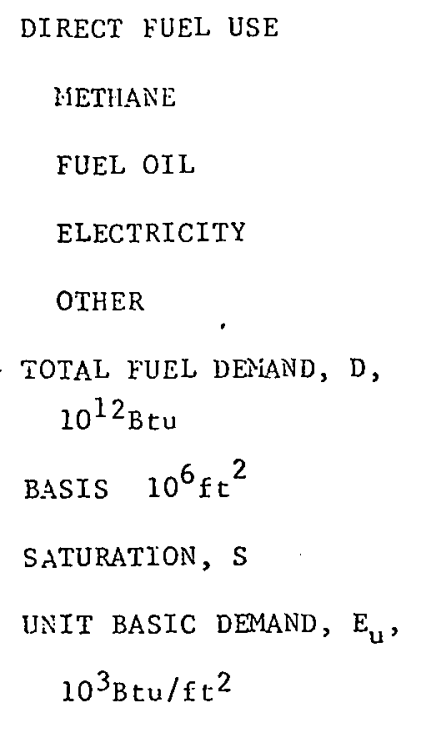

\begin{tabular}{|c|c|c|c|c|c|c|c|c|}
\hline \multicolumn{3}{|c|}{1972} & \multicolumn{3}{|c|}{1985} & \multicolumn{3}{|c|}{2000} \\
\hline $\mathrm{f}_{i}$ & $e_{i}$ & $\mathrm{D}_{i}$ & $\mathrm{f}_{i}$ & $e_{i}$ & $D_{i}$ & $f:{ }_{i}$ & $c_{\mathbf{i}}$ & $D_{i .}$ \\
\hline 1 & & & & & & & & \\
\hline 0.036 & 1.8 & 0.36 & 0.02 & 1.8 & 0.39 & 0.01 & 1.8 & 0.43 \\
\hline 0.964 & 3.0 & 5.77 & 0.98 & 3.0 & 10.53 & 0.99 & 3.0 & 25.54 \\
\hline & & 6.13 & & & 10.92 & & & 25.97 \\
\hline & & 440 & & & 878 & & & 2108 \\
\hline 1.00 & & & 1.00 & & & 1.00 & & \\
\hline & & 40.80 & & & 36.72 & & & 36.72 \\
\hline
\end{tabular}

REFERENCE TECHNOLOGIES:

DATA SOURCES :

3ASIS OF PROJECTIONS: 
FUEL MIX TABLE

$$
\mathrm{A}-50
$$

Region: II

Sector: COMERCIAL

Category: SCHCOL

End-use: AIR CONDITIONING

\begin{tabular}{|c|c|c|c|c|c|c|c|c|c|}
\hline & \multicolumn{3}{|c|}{1972} & \multicolumn{3}{|c|}{1985.} & \multicolumn{3}{|c|}{2000} \\
\hline & $f_{i}$ & $e_{i}$ & $D_{i}$ & $f_{i}$ & $e_{i}$ & $\mathrm{D}_{\mathrm{i}}$ & $f_{j .}$ & $e_{i}$ & $D_{i}$ \\
\hline DIRECT FUEL USE & & & & & & & & & \\
\hline $\begin{array}{l}\text { METHANE } \\
\text { FUEL OIL }\end{array}$ & 0.004 & 1.8 & 0.03 & 0.006 & 1.8 & 1.8 & 0.004 & 1.8 & 0.06 \\
\hline $\begin{array}{l}\text { ELECTRICITY } \\
\text { OTHER }\end{array}$ & 0.196 & 3.0 & 0.94 & 0.294 & 3.0 & 3.0 & 0.396 & 3.0 & 3.48 \\
\hline $\begin{array}{l}\text { TOTAL FUEL DEMAND, D, } \\
10^{12} \mathrm{Btu}\end{array}$ & & & 0.97 & & & 1.87 & & & 3.54 \\
\hline BASIS $10^{6} \mathrm{ft}^{2}$ & & & 447 & & & 39 & & & 912 \\
\hline SATURATION, S & 0.20 & & & 0.30 & & & 0.40 & & \\
\hline $\begin{array}{l}\text { UNIT BASIC DEMAND, E } \\
1 u^{3} \mathrm{Btu} / \mathrm{t} \mathrm{t}^{2}\end{array}$ & & & 32.10 & & & 28.89 & & & 28.89 \\
\hline
\end{tabular}

REFERENCE TECHNOLOGIES:

DATA SOURCES:

BASTS OF PROTECTTONS: 
FUEL MIX TABLE

A-51

Region: II

Sector: CONMERCIAL

Category: HOSPITAL

Fnd-use: AIR CONDITIONING

DIRECT FUEL USE

METHANEE

FUEL OIL

ELECTRICITY

OTHER

TOTAL FUEL DEMAND, D, $10^{12} \mathrm{Btu}$

BASIS $10^{6} \mathrm{ft}^{2}$

SATURATION, S

UNIT BASIC DEMAND, $\mathrm{E}_{\mathbf{u}}$,

$$
10^{3} \mathrm{Btu} / \mathrm{ft}^{2}
$$

REFERENCE TECHNOLOGIES:

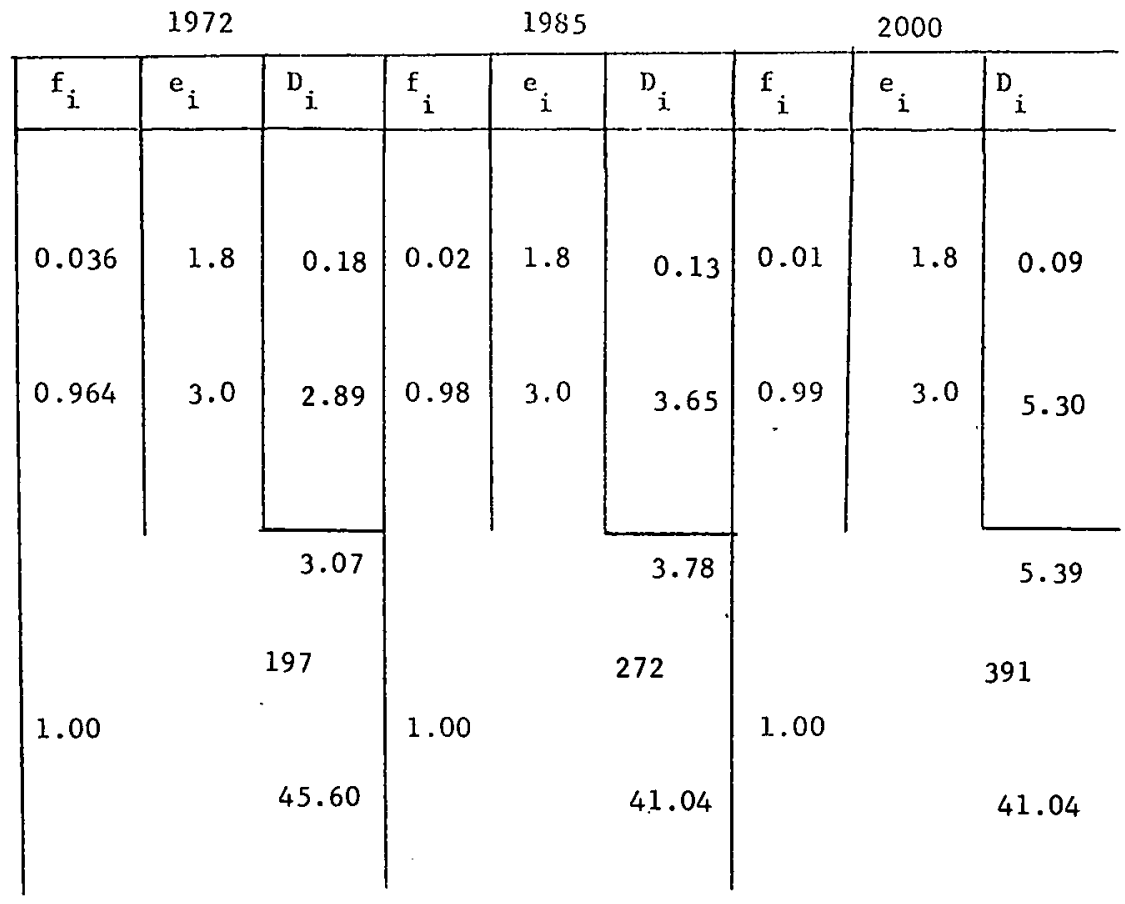

DATA SOURCES :

BASIS OF PROJECTIONS: 
FUEL MIX TABLE

A-52

Region: II

Sector: COMBERCINL

Category: MISCELLANEOUS

End-use: AIR CONDITIONING

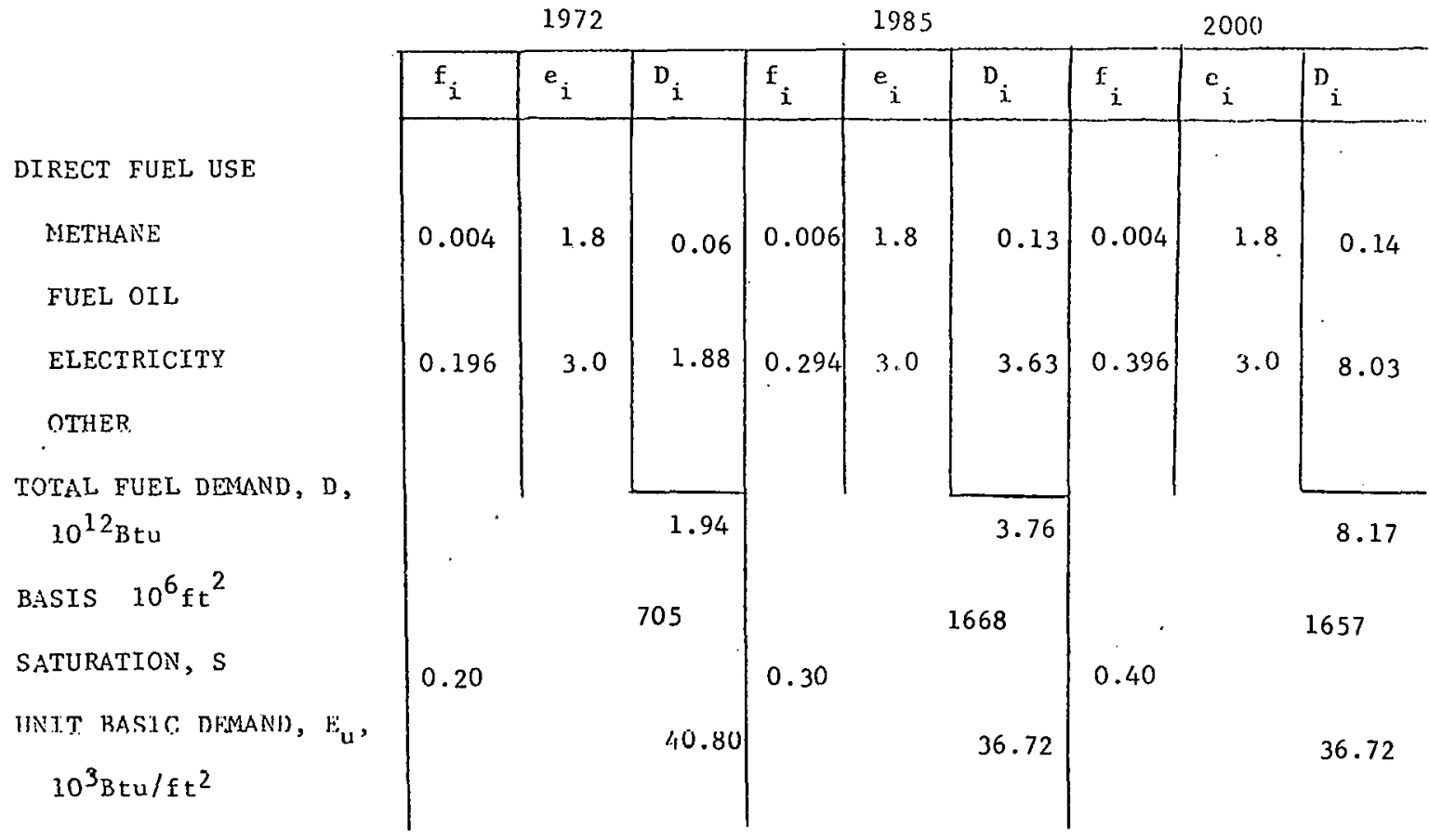

RETERENCE TECHNOLOGIES:

DATA SOURCES: .

BASTS OF PROJECTIONS: 
FUEL MIX TABLE

A-53

Region: II

Sector: COMMERCIAL

Category: ALL BUILDINGS

End-use: WATER HEATING

DIRECT FUEL USE

METHANE

FUEL OIL

ELECTRICITY

OTHER

TOTAL FUEL DEMAND, D, $10^{12} \mathrm{Btu}$

BASIS $10^{6} \mathrm{ft}^{2}$

SATURATION, S

1972

1985

2000

\begin{tabular}{|c|c|c|c|c|c|c|c|c|}
\hline$f_{i}$ & $e_{i}$ & $D_{i}$ & ${ }_{i}$ & $e_{i}$ & $\mathrm{D}_{i}$ & ${ }_{i}$ & ${ }^{e}{ }_{i}$ & $D_{i}$ \\
\hline 0.68 & 0.70 & 36.15 & 0.42 & 0.70 & 36.50 & 0.40 & 0.26 & 46.84 \\
\hline 0.32 & 1.00 & 12.05 & 0.58 & 1.00 & 35.28 & 0.60 & 1.00 & 49.15 \\
\hline . & & 48.20 & & & 71.78 & & & 95.99 \\
\hline & & 2206 & & & 3578 & & & 6664 \\
\hline 1.00 & & & 1.00 & & & 1.00 & & \\
\hline & & 17.00 & & & 17.00 & & & 17.00 \\
\hline
\end{tabular}

REFERENCE TECHNOLOGIES:

DATA SOURCES:

BASIS OF PROJECTIONS: 


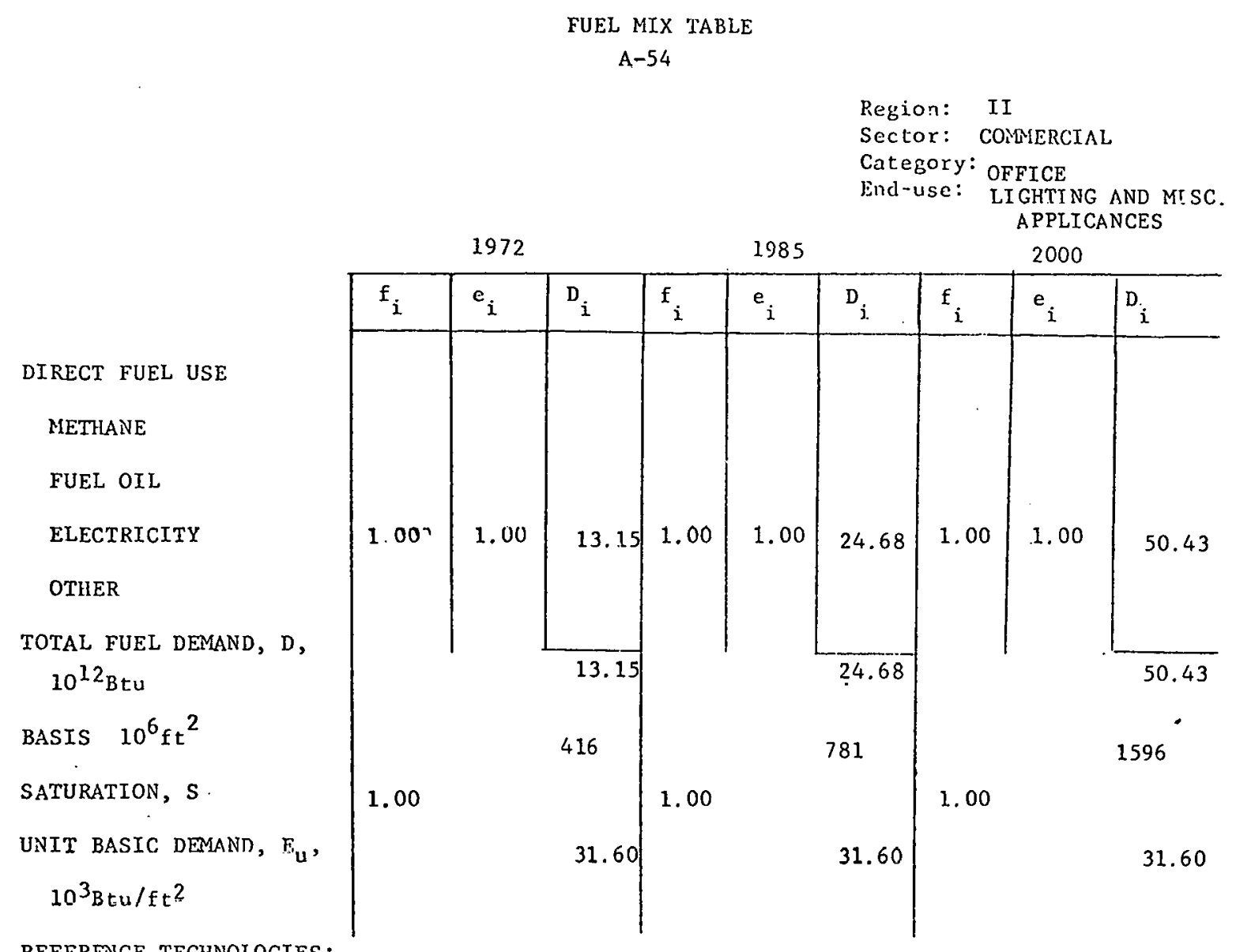

DATA SOURCES :

BASIS OF PROJECTIONS: 


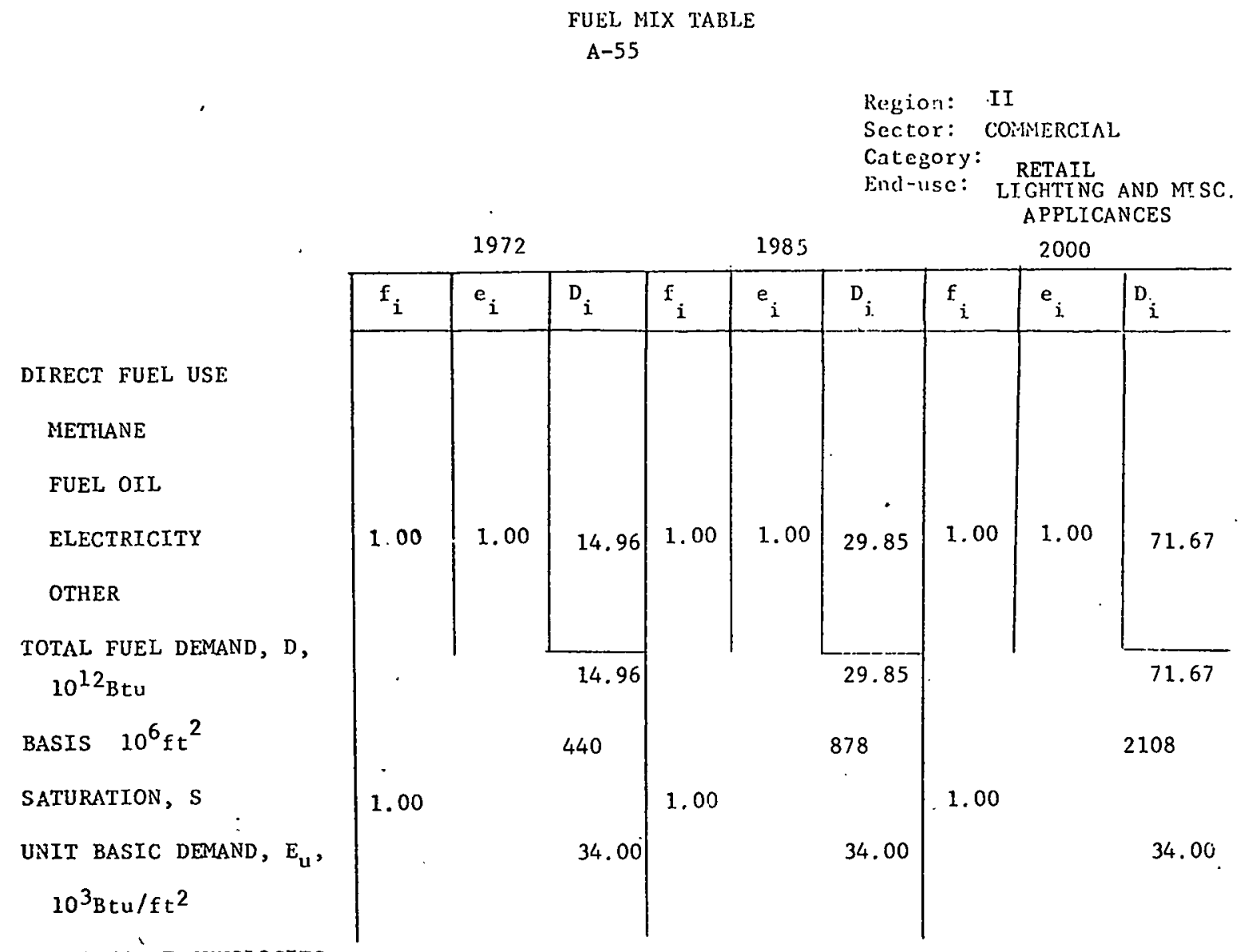

REFERENCE TECHNOLOGIES:

DATA SOURCES :

BASIS OF PROJECTIONS : 


\begin{tabular}{|c|c|c|c|c|c|c|c|c|c|}
\hline & & & $\begin{array}{r}\text { FUEL M } \\
\text { A-56 }\end{array}$ & $\begin{array}{l}\text { IX TAB } \\
5\end{array}$ & & & & & \\
\hline . & & & & & & $\begin{array}{l}\text { Regj. } \\
\text { Sect: } \\
\text { Cate } \\
\text { End- }\end{array}$ & $\begin{array}{l}\text { n: } \quad \text { II } \\
x: \text { co } \\
\text { ory: } \\
\text { se: } \quad \text { L }\end{array}$ & $\begin{array}{l}\text { MERCIA } \\
\text { HOOL } \\
\text { GHTING } \\
\text { APPLIC }\end{array}$ & $\begin{array}{l}\text { IND MT SC. } \\
\text { JCES }\end{array}$ \\
\hline & & 1972 & & & 1985 & & & 2000 & \\
\hline & $f_{i}$ & $e_{i}$ & $\mathrm{D}_{\mathrm{i}}$ & $\mathrm{f}_{i}$ & ${ }^{e}{ }_{i}$ & $\mathrm{D}_{\mathrm{i}}$ & $\mathrm{f}_{\mathrm{i}}$ & $e_{i}$ & $D_{i}$ \\
\hline $\begin{array}{l}\text { DIRECT FUEL USE } \\
\text { METHANE } \\
\text { FUEL OIL }\end{array}$ & & & & & & & & & \\
\hline $\begin{array}{l}\text { ELECTRICITY } \\
\text { OTHER }\end{array}$ & $1.00^{\prime}$ & 1.00 & 12.16 & 1.00 & 1.00 & 17.38 & 1.00 & 1.00 & 24.81 \\
\hline $\begin{array}{l}\text { TOTAL FUEL DEMAND, } D \\
\qquad 0^{12} \mathrm{Btu}\end{array}$ & & & 12.16 & & & 17.38 & & & 21,81 \\
\hline BASIS $10^{6} \mathrm{ft}^{2}$ & & & 447 & & & 639 & & & 912 \\
\hline SATURATION, S & 1.00 & & & 1.00 & & & 1.00 & & \\
\hline $\begin{array}{l}\text { UNIT BASIC DEMAND, } \mathrm{E}_{\mathrm{u}} \text {, } \\
10^{3} \mathrm{Bt} . \mathrm{ft} / \mathrm{ft}^{2}\end{array}$ & & & 27.20 & & & 27.20 & & & 27.20 \\
\hline
\end{tabular}

DATA SOURCES:

BASIS OF PROJECTIONS: 
FUEL MIX TABLE

$$
\text { A-57 }
$$

Region: II

Sector: COMHERCIAL

Category: HOSPITAL

End-use: LIGHTING AND MTSC. APPLICANCES

\begin{tabular}{|c|c|c|c|c|c|c|c|c|c|}
\hline & \multicolumn{3}{|c|}{1972} & \multicolumn{3}{|c|}{1985} & \multicolumn{3}{|c|}{2000} \\
\hline & $\mathrm{f}_{\mathrm{i}}$ & $e_{i}$ & $D_{i}$ & $\mathrm{f}_{\mathbf{i}}$ & $e_{i}$ & $D_{i}$ & $\mathrm{f}_{\mathrm{i}}$ & $e_{i}$ & $D_{i}$ \\
\hline $\begin{array}{l}\text { DIRECT FUEL USE } \\
\text { METHANE } \\
\text { FUEL OIL }\end{array}$ & & & & & & & & & \\
\hline $\begin{array}{l}\text { ELECTRICITY } \\
\text { OTHER }\end{array}$ & 1.00 & 1.00 & 14.05 & 1.00 & 1.00 & 19.39 & 1.00 & 1.00 & 27.88 \\
\hline $\begin{array}{l}\text { TOTAL FUEL DEMAND, } D \text {, } \\
10^{12} \mathrm{Btu}\end{array}$ & & & 14.05 & & & 19.39 & & & 27.88 \\
\hline BASIS $10^{6} \mathrm{ft}^{2}$ & & & 197 & & . & 272 & & & 391 \\
\hline SATURATION, $\mathrm{s}$. & 1.00 & & & 1.00 & & & 1.00 & & \\
\hline $\begin{array}{l}\text { UNIT BASIC DEMAND, } \mathrm{E}_{\mathrm{u}} \text {, } \\
10^{3} \mathrm{Btu} / \mathrm{ft}^{2}\end{array}$ & & & 71.30 & & & 71.30 & & & 71.30 \\
\hline
\end{tabular}

REFERENCE TECHNOLOGIES:

DATA SOURCES :

BASIS OF PROJECTIONS : 


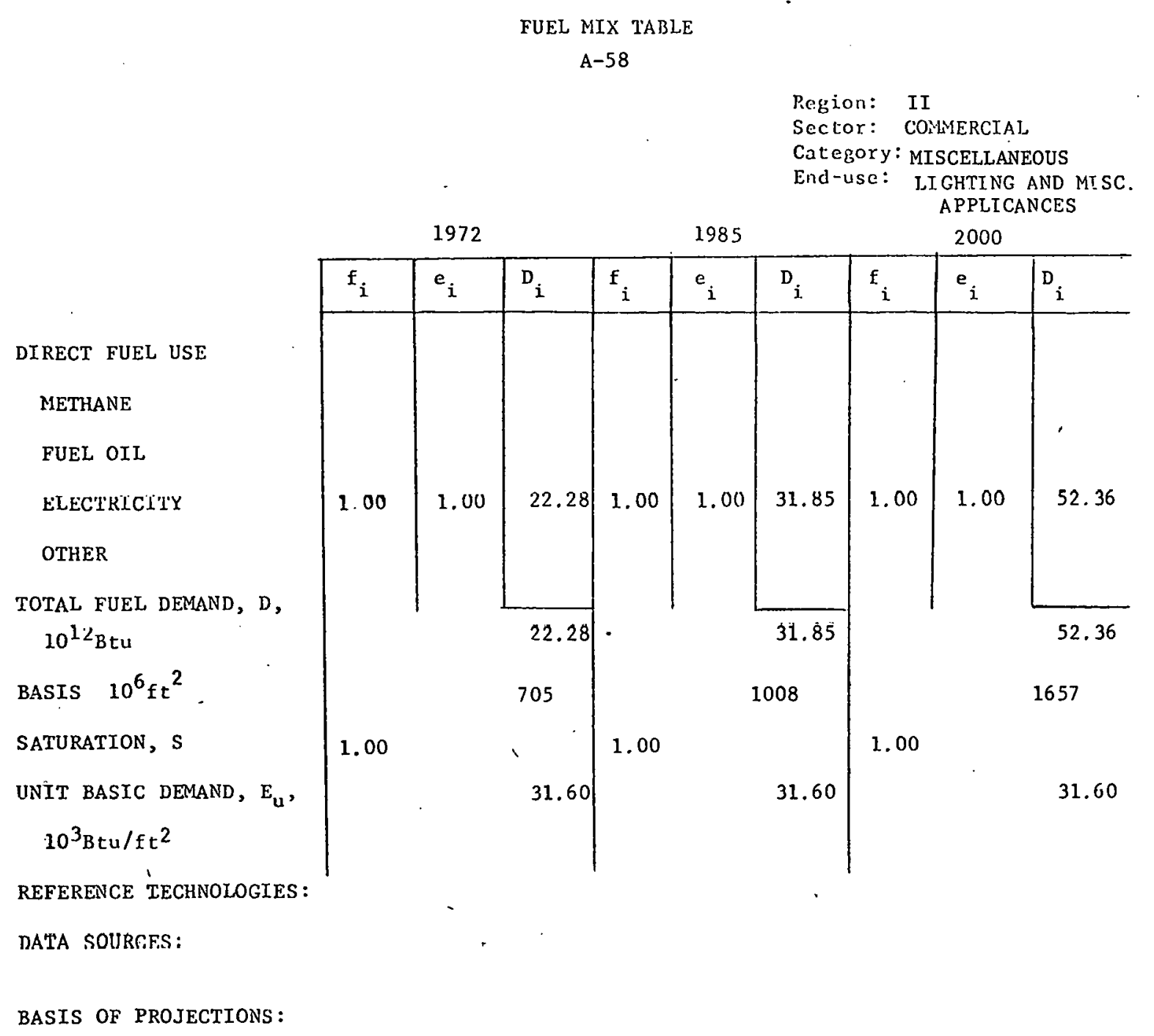


FUEL MIX TABLE

A-59
Region: III

Sector: RESIDENTIAL

Cate ? $x y:$ SINGLE FAMILY DETACHED End-Use: SPACE HEATING
DIRECT FUEL USE

METHANE

Existing

Retrofitted

New-Improved

New-FHA-MPS

FUEL OIL

Existing

Retrofitted

New-improved

New-FHA-MPS

ELECTRICITY

Existing

New-Improved

Heat pump

OTHER (Coal)

TAL FUEL DEMAND, D, $10^{12} \mathrm{Btu}$

BASIS ,

$10^{3}$ Households

SATURATION, S

1.00

UNIT BASIC DEMAND, $E_{u}$

$10^{6} \mathrm{Btu} / \mathrm{household}$

Existing

New

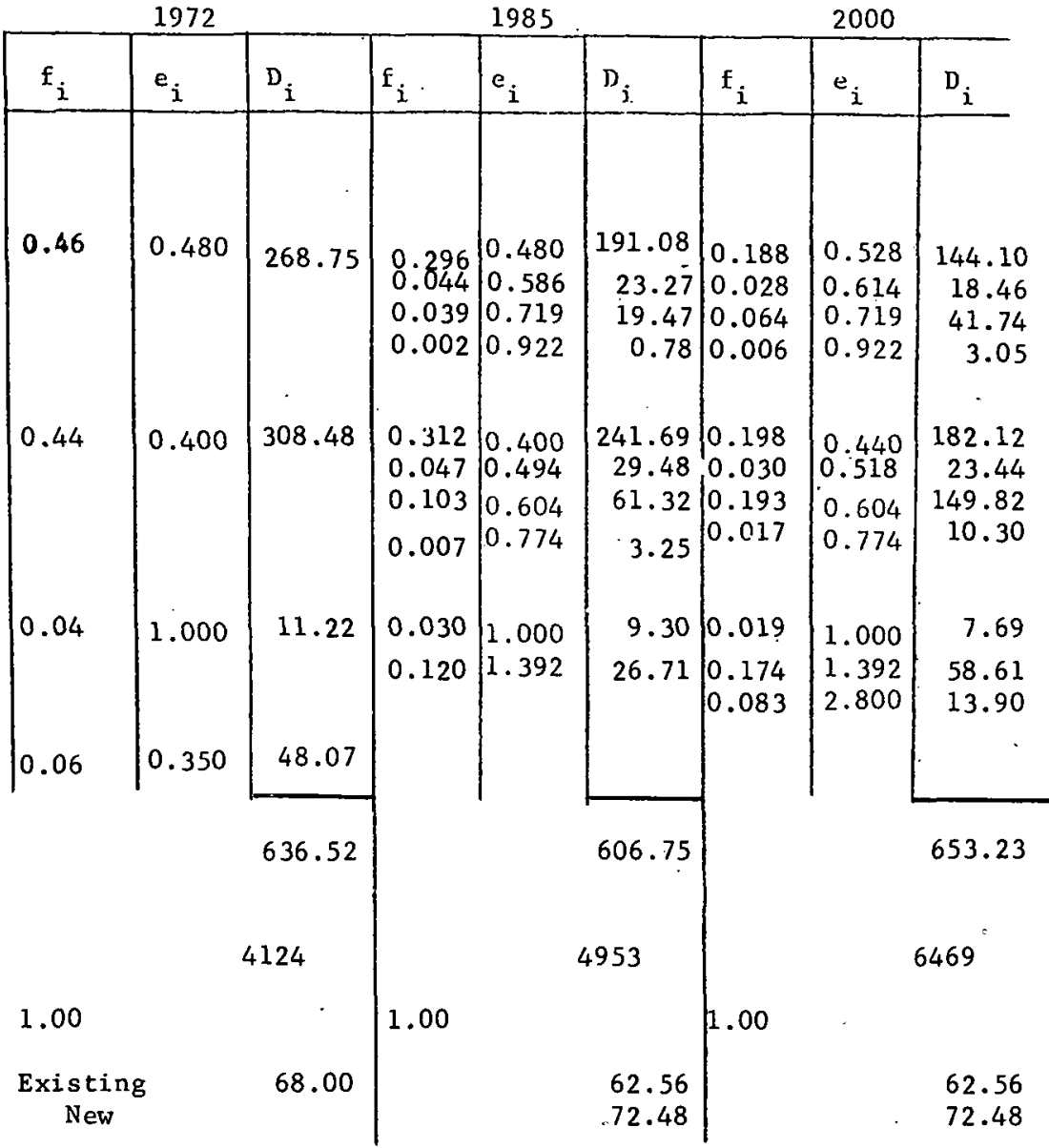

REFF.RFNR.F. TF.SHNOLOGIF.S :

DATA SOURCES :

BASIS OF PROJECTION:

Noto: Fnr al1 Region TTT tahles for the residentiall sector. see corresponding Region I tables for reference technologies, data sources, and basis of projection. 


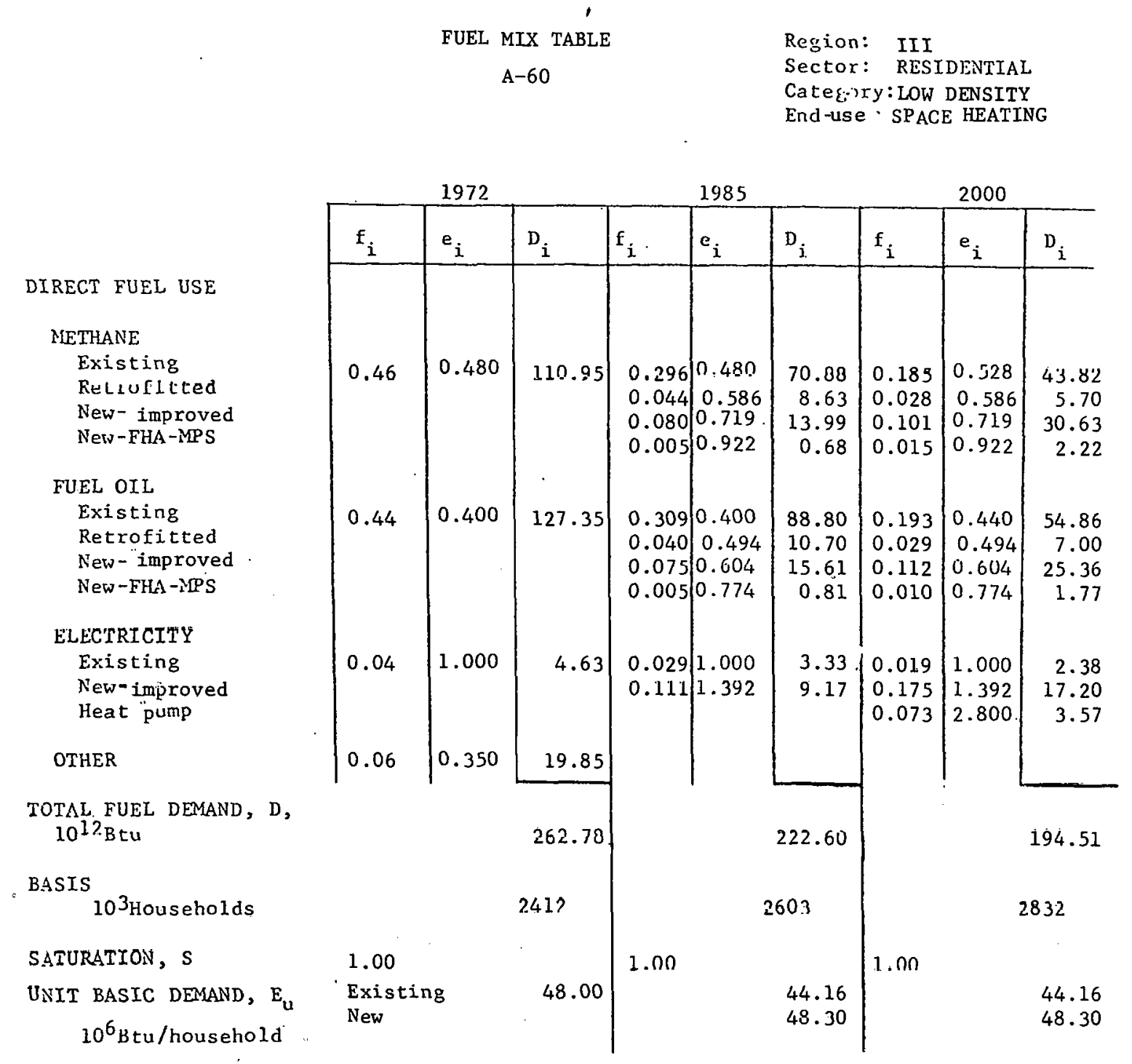

REFERENCE TECHNOLOGIES:

DATA SOURGES:

DA3IS OF FROJECTTON: 
FUEL MIX TABLE

A-61
Region: III

Sector: RESIDENTIAL

Category: LOW RISE

End-use: SPACE HEATING

DIRECT FUEL USE

NETHANE

Existing

Retrofitted

New $-i$ mproved

New-FHA-MPS

FUEL OIL

Existing

Retrofitted

New - improved

New-FHA-MPS

ELECTRICITY

Existing

Ncw-imp roved

Heat pump

OTHER

TOTAL FUEL DEMAND, $D$, $10^{12}$ Btu

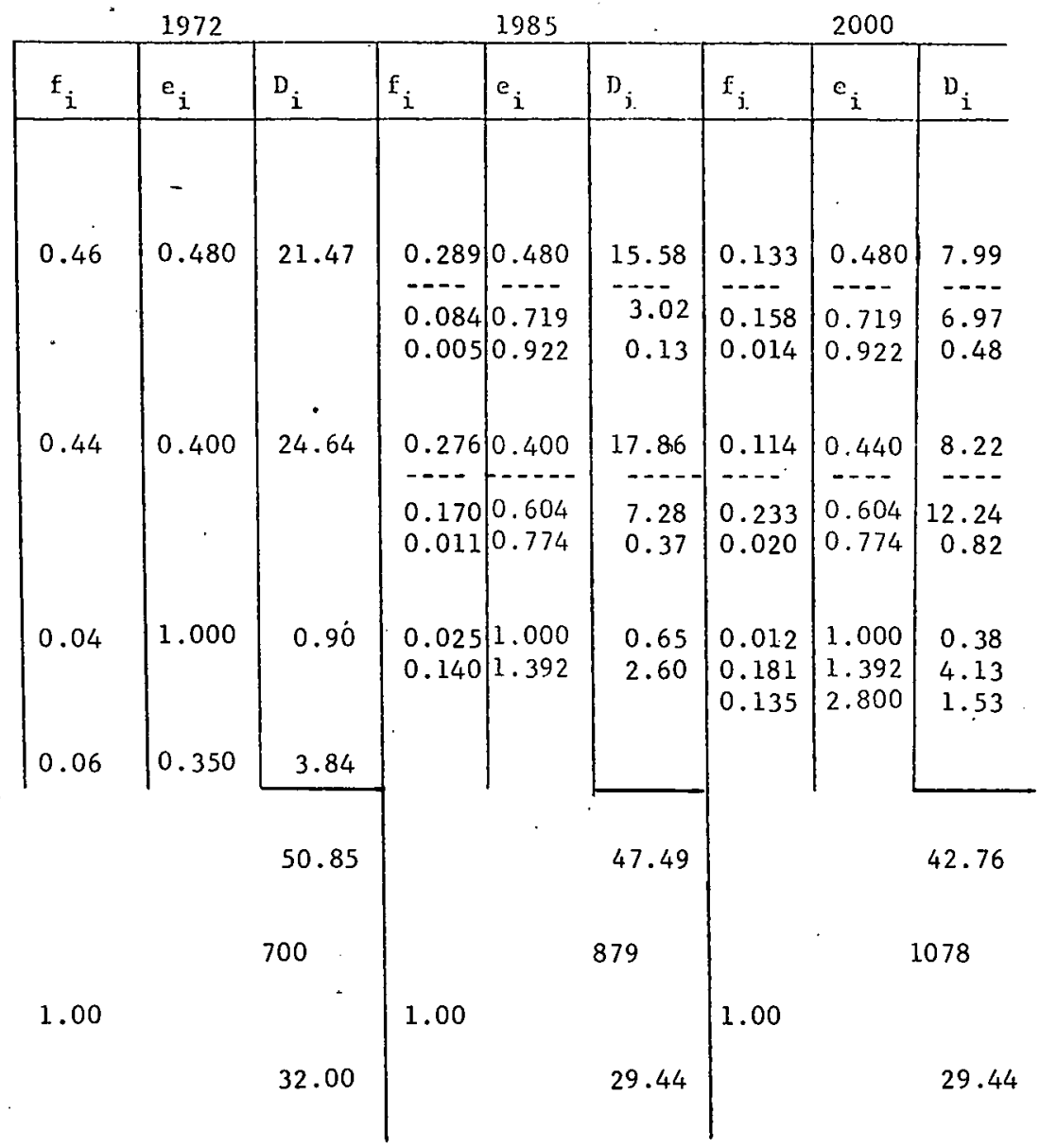

REFERENCE TECHNOLOGIES:

DATA SOURCES:

BASIS OF PROJECTION : 
FUEL MIX TABLE

A-62
Region: III

Sector: RESIDENTIAL

Catequry: HIGH RISE

End use: SPACE HEATING
DIRECT FUEL USE

METHLANE

Existing

Retrofitted

New-improved

Nerv-FHA-MPS

FUEL OIL

Existing

Retrofitted

New - improved

New-FHA-MPS

ELECTRICITY

Existing

New - improved

lleat pump

OTHER (Coa1)

TOTAL FUEL DEMAND, D $10^{12} \mathrm{Btu}$

BASIS

$10^{3}$ Households

3ATURATION, $S$

UNIT BASIC DFMAND, Fu

$10^{6} \mathrm{Btu} /$ household

REFERENCE TECHNOLOGIES:

DATA SOUREES:

BASIS OF PROJECTION:

\begin{tabular}{|c|c|c|c|c|c|c|c|c|}
\hline & 1972 & & & 1985 & & & 2000 & \\
\hline $\mathrm{f}_{\mathbf{i}}$ & $e_{i}$ & $\mathrm{D}_{i}$ & $\mathrm{f}_{\mathrm{i}}$ & $e_{i}$ & $\mathrm{D}_{\mathrm{i}}$ & $f_{i}$ & $e_{i}$ & $\mathrm{D}_{\mathrm{i}}$ \\
\hline 0.46 & 0.480 & 15.67 & $\begin{array}{l}0.331 \\
=-.- \\
0.100 \\
0.001\end{array}$ & $\mid \begin{array}{l}0.480 \\
-0.719 \\
0.9 ? ?\end{array}$ & $\begin{array}{c}10.85 \\
-. \\
2.19 \\
0.1 .1\end{array}$ & $\begin{array}{l}0.188 \\
0.194 \\
0.017\end{array}$ & $\begin{array}{l}0.480 \\
-. .8 \\
0.719 \\
0.922\end{array}$ & $\begin{array}{l}6.15 \\
=--- \\
4.66 \\
0.32\end{array}$ \\
\hline 0.14 & 0.400 & 17.99 & $\begin{array}{l}0.347 \\
--- \\
0.091 \\
0.006\end{array}$ & \begin{tabular}{l}
0.400 \\
\hdashline 0.604 \\
0.774
\end{tabular} & $\begin{array}{l}13.65 \\
-.37 \\
0.12\end{array}$ & $\begin{array}{l}0.193 \\
-. .1 \\
0.131 \\
0.012\end{array}$ & $\begin{array}{c}0.440 \\
-.- \\
0.604 \\
0.774\end{array}$ & $\begin{array}{l}7.58 \\
-.-1 \\
3.75 \\
0.27\end{array}$ \\
\hline 0.06 & $\begin{array}{l}1.000 \\
0.350\end{array}$ & 0.65 & $\begin{array}{l}0.030 \\
0.088\end{array}$ & $\begin{array}{l}1.000 \\
1.392\end{array}$ & $\begin{array}{l}0.47 \\
1.00\end{array}$ & $\begin{array}{l}0.017 \\
0.164 \\
0.084\end{array}$ & $\begin{array}{c}1.000 \\
1.393 \\
2.800 \\
-\end{array}$ & $\begin{array}{l}0.30 \\
2 . \cap 4 \\
0.52\end{array}$ \\
\hline . & & $\begin{array}{l}34.31 \\
545\end{array}$ & & & $\begin{array}{l}30.10 \\
570\end{array}$ & & & $\begin{array}{l}25.59 \\
626\end{array}$ \\
\hline $1 . \dot{U}$ & & 30.00 & 1.00 & & 27.60 & 1.00 & . & 27.60 \\
\hline
\end{tabular}


FUEL MIX TABLE

A-63

Region: III

Sector: RESIDENTIAL

Category: MOBILE HOME

End-use: SPACE HEATING

DIRECT FUEL USE

METILANE

Existing

Retrofitted

New - improved

New-FHA-MPS

FUEL OIL

Existing

Retrofitted

New-imp roved

New -FHA -MPS

ELECTRICITY

Existing

New-improved

Heat P ump

OTHER

TOTAL FUEL DEMAND, D, $10^{12} \mathrm{Btu}$

BASIS

$10^{3}$ Households

Negligible

SATURATION, S

UNIT BASIC DEMAND, $E_{u}$

$10^{6} \mathrm{Bcu} /$ househuld.

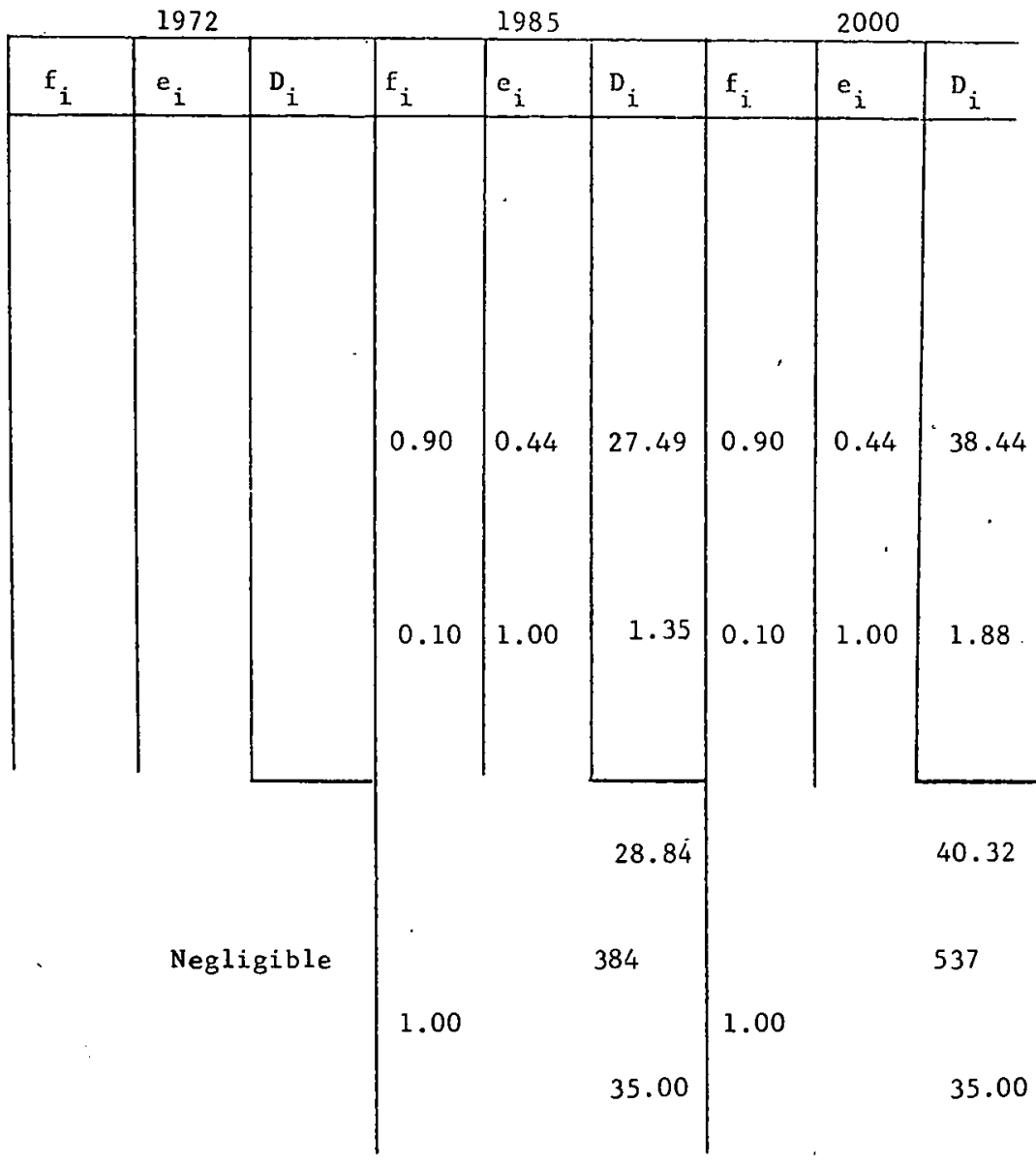

REFERENCE TECHNOLOGIES :

DATA SOURCES :

BASIS OF PROJECTION : 
FUEL MIX TAIBLE:

A-64

Region: III

Sector: RESIDJNSIAL

Category: ALL HOUSING TYPES

End-use: AIR CONDITIONING

DIRECT FUEL USE

METHANE

Existing

Retrofitted

Nerv-improved

NeV-FHA-NPS

FUEL OIL

Fristing.

Retrofitted

Neris - improvorl

New-FHA - RPS

ELECTRICLTY

ROOM

CENTRAL

OTHER

TOTAL FUEL DEMAND, D, $10^{12} \mathrm{Btu}$

21.35

RASTSS

$10^{3}$ Househo $1 \mathrm{ds}$

0.32

0.10

14.57

1972

1985

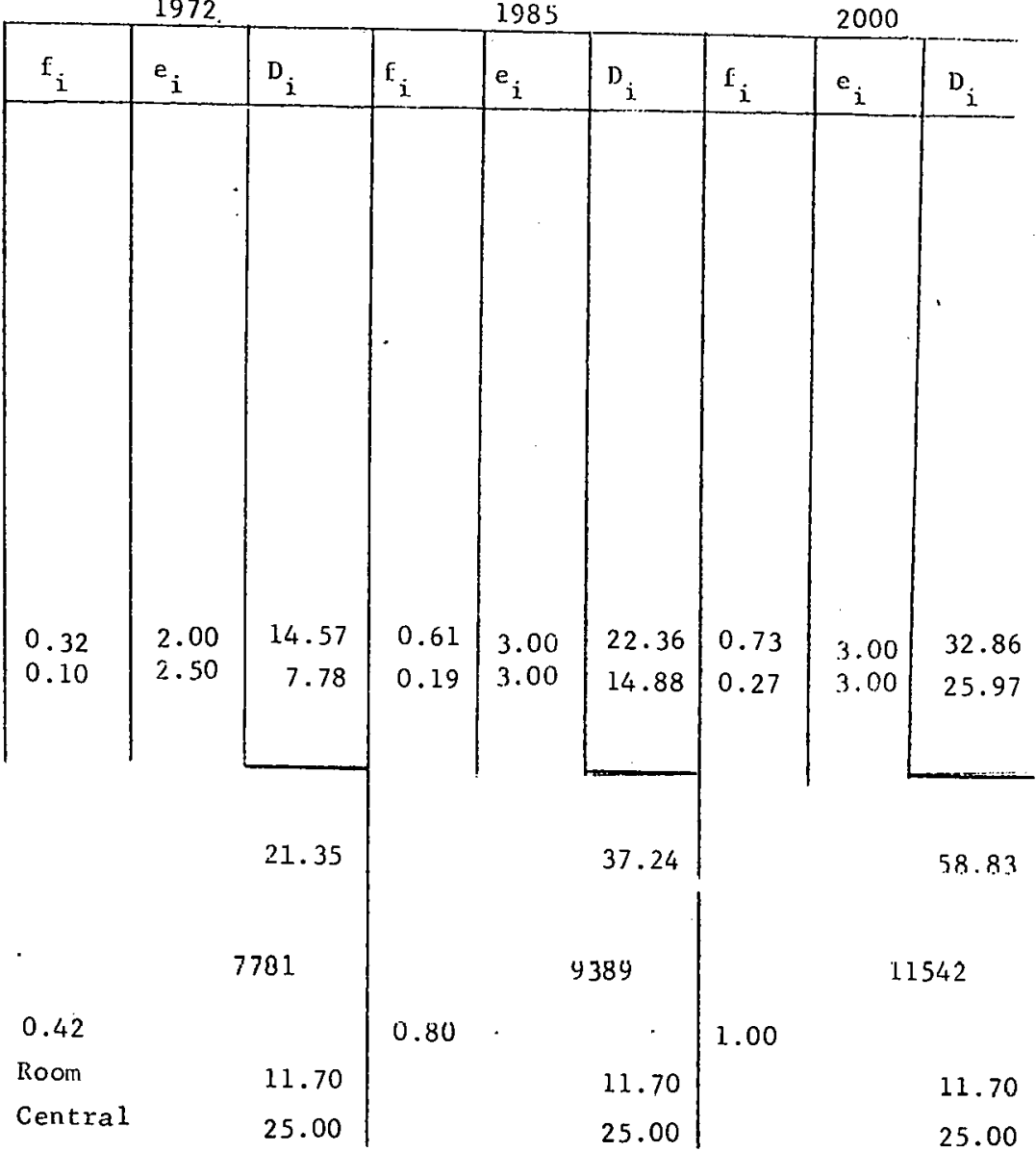

SATURATION,

UNIT BASIC DEIAND, $E_{u}$

$10^{6} \mathrm{Btu} /$ household

25.00

25.00

25.00

REFERENCE TECHNOLOGIES:

DATA SOURCES:

BASIS OI IROJECTIOR. 
FUEL MIX TABLE

$$
\text { A-65 }
$$

Region: III

Sector: RESCDENTIAJ

Category: SINGLE FAMILY DETACHED

EncLuse: WATTER HEATING

DIRECT FUEL USE

METHANE

Existing

Retrofitted

New-improved

New - FHA-MPS

FUEL OIL

Existing

Retrofitted

New-improved

New-FHA-MPS

ELECTRICITY

Existing

New-Imp roved

Heat pump

\section{OTHER}

TOTAL FUEL DEMAND, D, $10^{12 \mathrm{Btu}}$

BASIS

$10^{3}$ Households

SATURATION, $S$

1.00

UNIT BASIC DEMAND, $E_{\mathbf{u}}$ $10^{6} \mathrm{Btu} /$ household

REFERENCE TECHNOLOGIES:

DATA SOURCES:

BASIS OF PROJECTION:

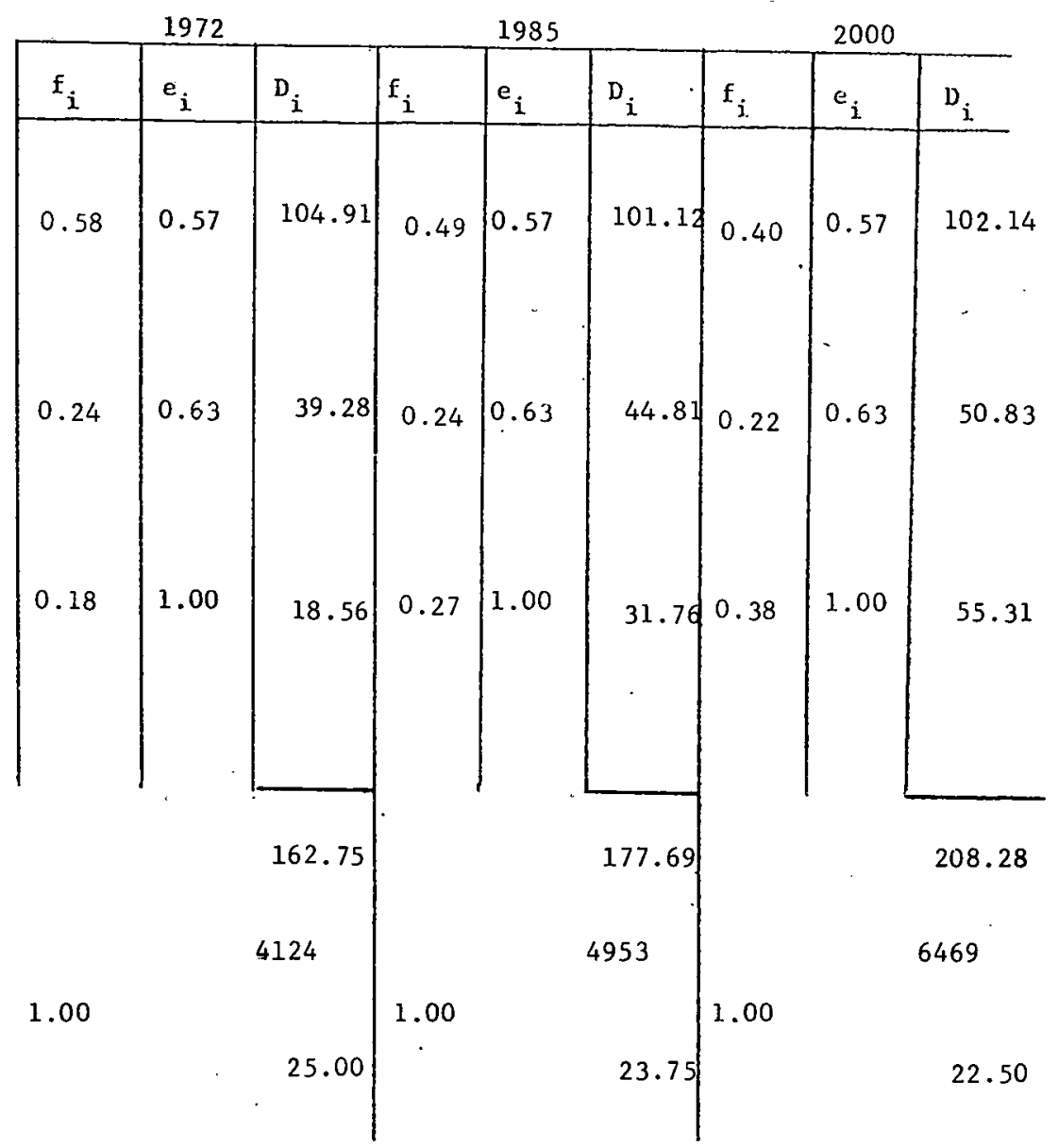


FUEL. MLX T $\triangle B L E$

A-66

Region: III

Sector: RESTJJENTSAI,

Category: LOW DENSITY

End-use; WATER HEATING

DIRECT FUEL USE.

METHANE

Existing

Retrofitted

New-improved

New-FHA-iPS

FUET. OIL

Existing

Retrofitted

New-improved

New-FHA-NPS

ELECTRICTTY

Existing

New-improved

Heat pump

OTIER

TOTAL FUEL DESAND, D, $10^{12}$ Btu

BASIS

10 Households

SATURATION, $S$

1.00

UNIT BASIC DERLAND, $E_{\mathrm{u}}$

$10^{6} \mathrm{Btu} /$ household

REFERESCF, TFCHNOTISTES :

DATA SOURCES:

PASTS OF PROIECTION:

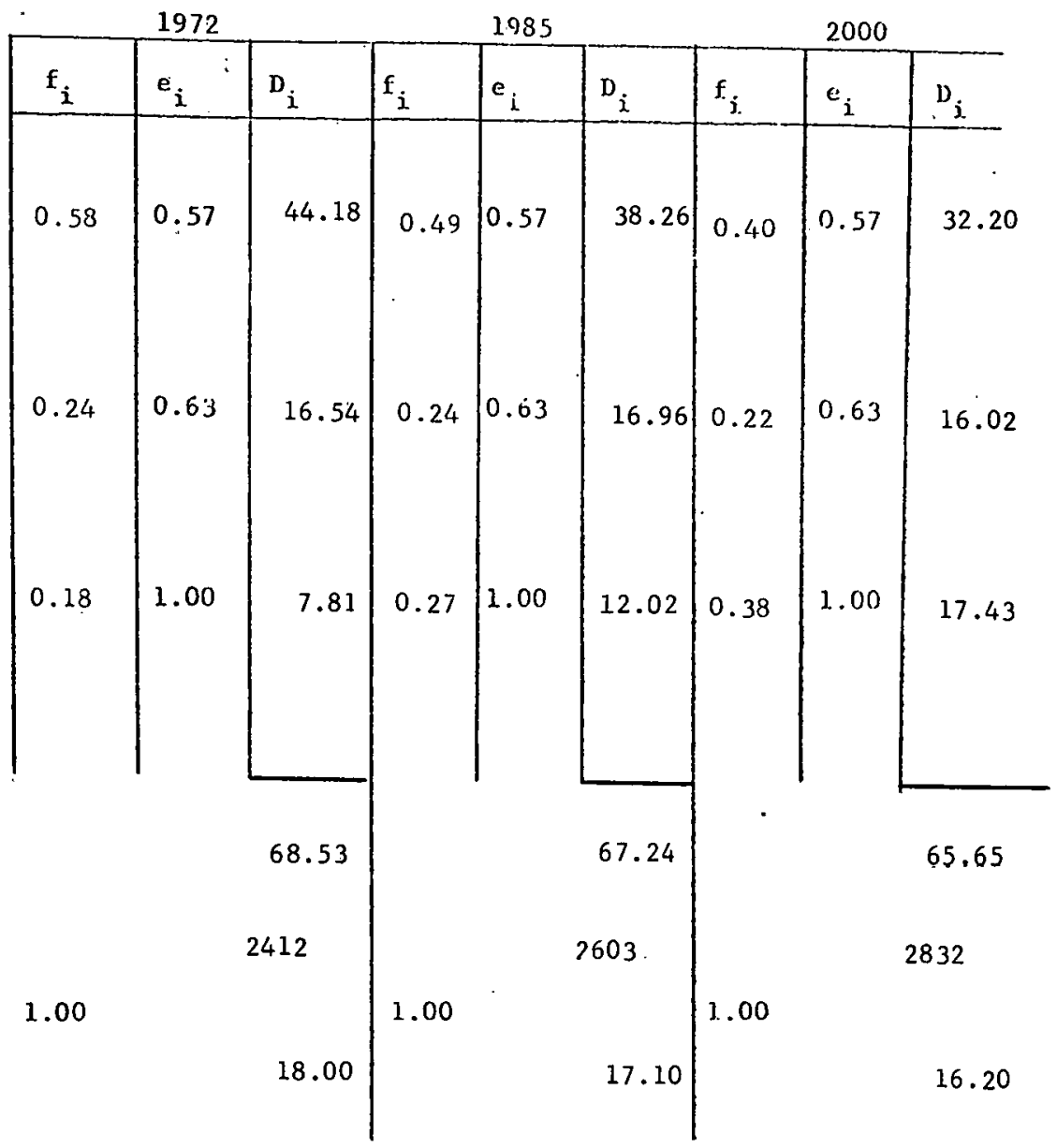


FULL NLX TABLE

$$
\text { A-67 }
$$

Region: III

Sector: RESIDENTIAL

Cat:cgory: LOW RISE

End-Use: WATER HEATING

DIRECT FUEL USE

METHANE

Existing

Retrofitted

New-I.np roved

New-FHA-MPS

FUEL OIL

Existing

Retrofitted

New improved

New-FHA-MPS

ELECTRICITY

Existing

New-improved

Heat ipump

OTHER

TOTAL FUEL DEMAND, D, $10^{12} \mathrm{Btu}$

-

BASIS

$10^{3}$ Households

SATURATION, S

1.00

\begin{tabular}{|l|l|}
\hline$f_{i}$ & $e_{i}$ \\
\hline 0.58 & 0.57 \\
0.24 & 0.63 \\
0.18 & 1.00
\end{tabular}

972

1985

\begin{tabular}{|l|l|l|l}
\hline$D_{i}$ & $f_{j .}$ & $e_{i}$ & $D_{i}$ \\
\hline 11.49 & 0.40 & 0.57 & 10.89 \\
5.09 & 0.22 & 0.63 & 5.42 \\
3.61 & 0.38 & 1.00 & 5.90 \\
& & &
\end{tabular}

17.69

20.19

22.21

700

879

1.00

1.00

1078

UNIT BASIC DEMAND, $\mathbf{E}_{\mathbf{u}}$

$$
\text { - } 10^{6} \mathrm{Btu} / \text { household }
$$

16.00

15.20

14.40

REFERENCE TECHNOLOGIES:

DATA SOURCES:

BASIS OF PROJECTION: 
FUEL MLX JABLE

A-68

Region: III

Sector: RESIDENTIAL

Cáccsory: HIGH RISE

End-Use: : WATER HEATING

DIRECT FUEL USE

METHANE

Existing

Retrofitted

New-improved

New -FHA-MPS

FUEL OTL

Existing

Rotrnfittod

New $-i$ mproved

New-FHA-MPS

ELECTRICITY

Existing

New-improved

Heat pump

OTHER

TOTAL FUFI. DEMAND, D, $10^{12} \mathrm{Btu}$

\begin{tabular}{|c|c|c|c|c|c|c|c|c|}
\hline \multicolumn{3}{|c|}{1972} & \multicolumn{3}{|c|}{1985} & \multicolumn{3}{|c|}{2000} \\
\hline $\mathbf{f}_{\mathbf{i}}$ & $e_{i}$ & $D_{i}$ & $f_{i}$ & $e_{i}$ & $D_{i}$ & ${ }^{f}$. & $e_{i}$ & $\mathrm{D}_{i}$ \\
\hline 0.58 & 0.57 & 8.87 & 0.49 & 0.57 & 7.45 & 0.40 & 0.57 & 6.33 \\
\hline 0.24 & 0.63 & 3.32 & 0.24 & 0.63 & 3.30 & 0.22 & 0.63 & 3.15 \\
\hline 0.18 & 1.00 & 1.57 & 0.27 & 1.00 & 2.34 & 0.38 & 1.00 & 3.43 \\
\hline & & 13.76 & & & 13.09 & & & 12.91 \\
\hline & & 545 & & & 570 & & & 626 \\
\hline 1.00 & & & 1.00 & & & 1.00 & & \\
\hline & & 16.00 & & & 15.20 & & & 16.40 \\
\hline
\end{tabular}

REFERENCE TECHNOLOGIFS:

DATA SOURCES:

BAEIS OF PROJECTION: 
FUEL MIX TABLE

A -69

Region: III

Sector: RESTDENTIAL

Category: MOBILE HOME

End use: - WATER HEATING

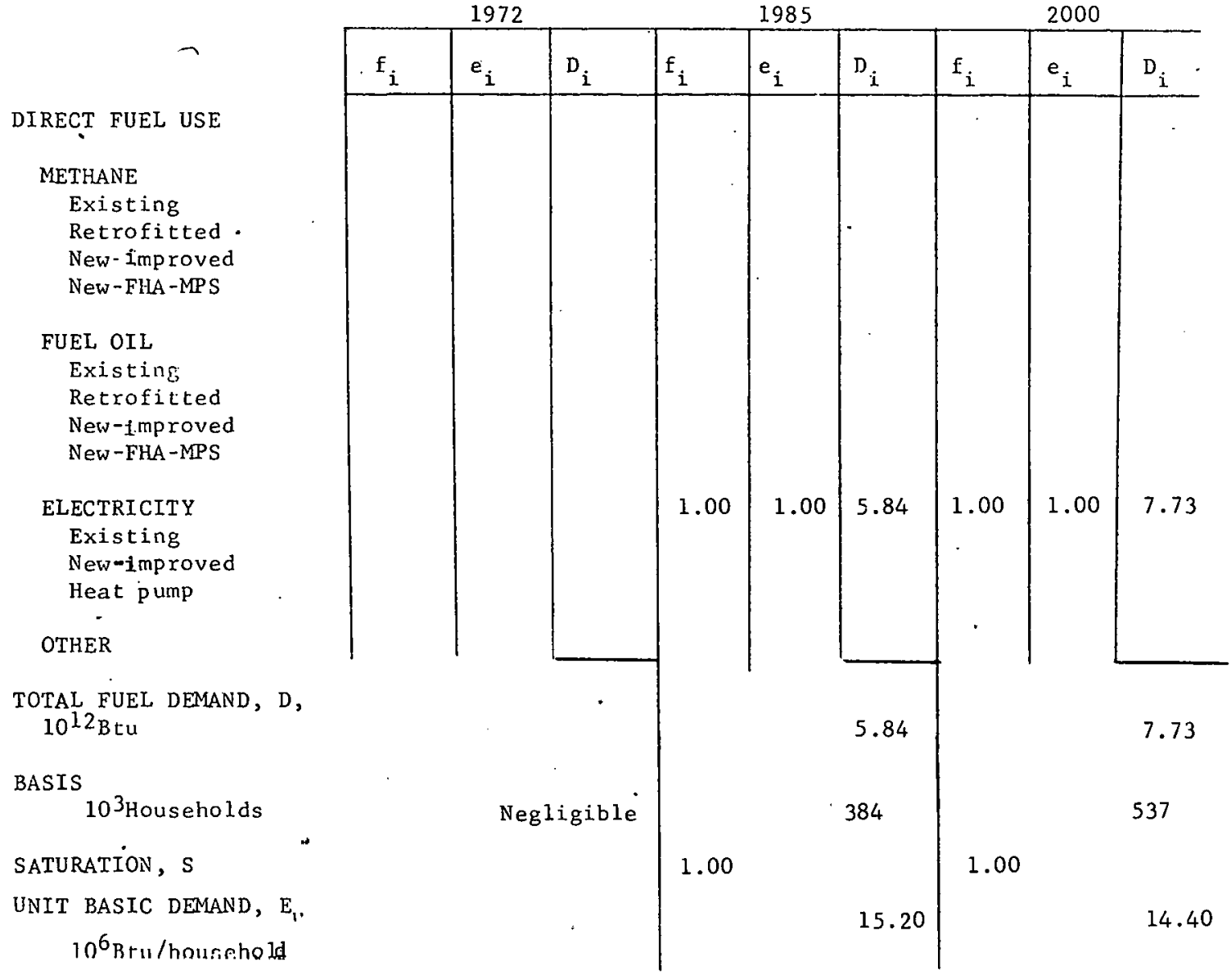

REFERENCE TECHNOLOGIES:

DATA SOURCES:

BASIS OF PROJECTION: 


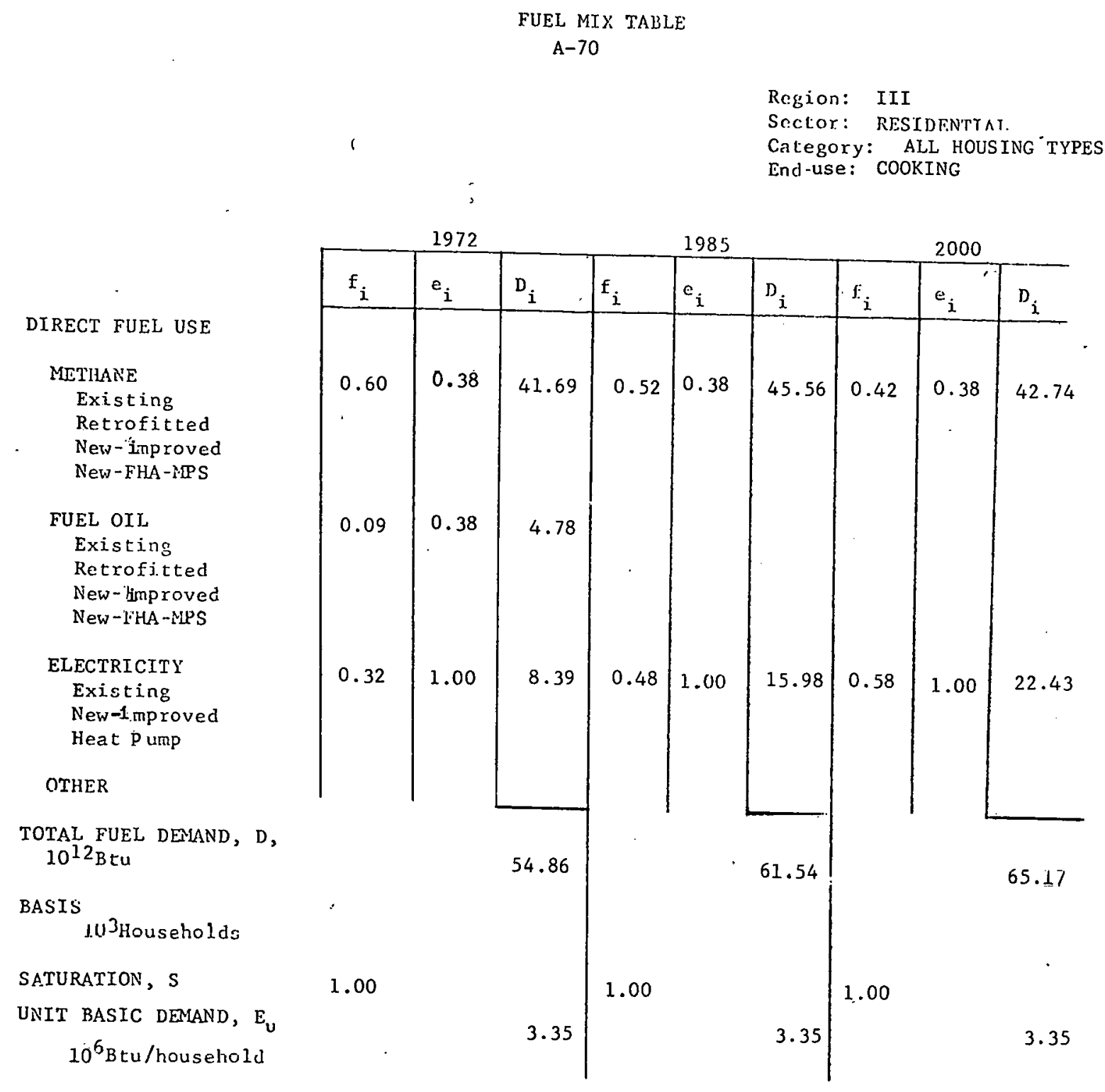

REFERENCE TECHNOLOGIES:

DATA JOURCE3:

BASIS OF PROJECTION: 
FUEL MIX TABI.E

$$
\text { A }-71
$$

Region: III

Sector: RESIDENTIAL

Category: ALL HOUSING TYPES

End-Use: LIGHTING AND MISC.

ELECTRIC APPLIANCES

DIRECT FUEL USE

METHANE

Existing

Retrofitted

New-improved

New -FH.'-MPS

FUEL OIL

Existing

Retrofitted

New - improved

New-FHA-MPS

\section{ELECTRICITY}

Existing

New-improved

Heat pump

\section{OTHER}

TOTAL FUEL DEMAND, D, $10^{12} \mathrm{Btu}$

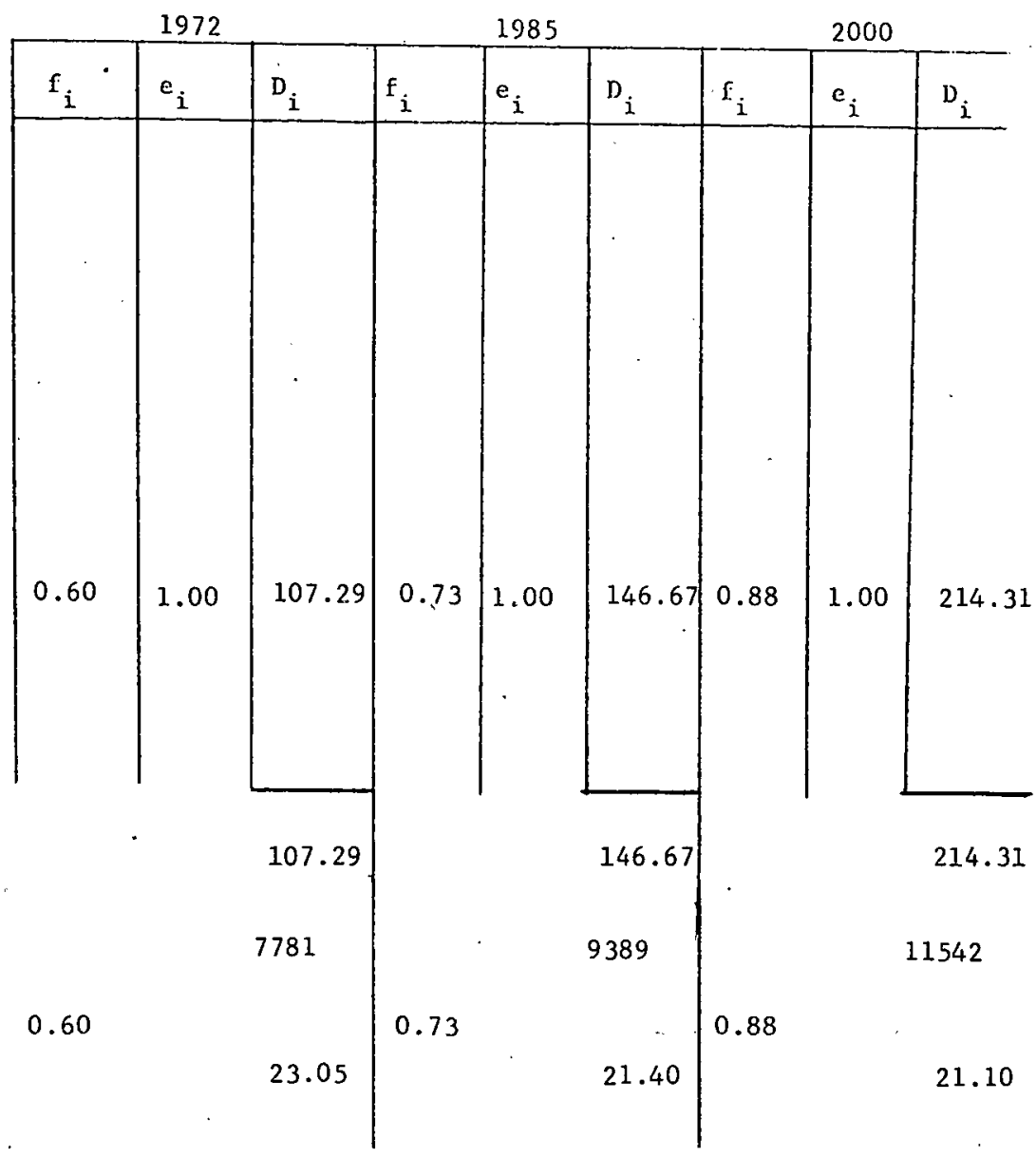

REFERENCE TECHNOLOGIES:

DATA SOURCES:

BASIS OF PROJECTION: 
FULI, HCX TABLE

A-72

Region: III

Sector: COMMRCIAL

Category: OFFICE

End-usc: SPACE HEATING

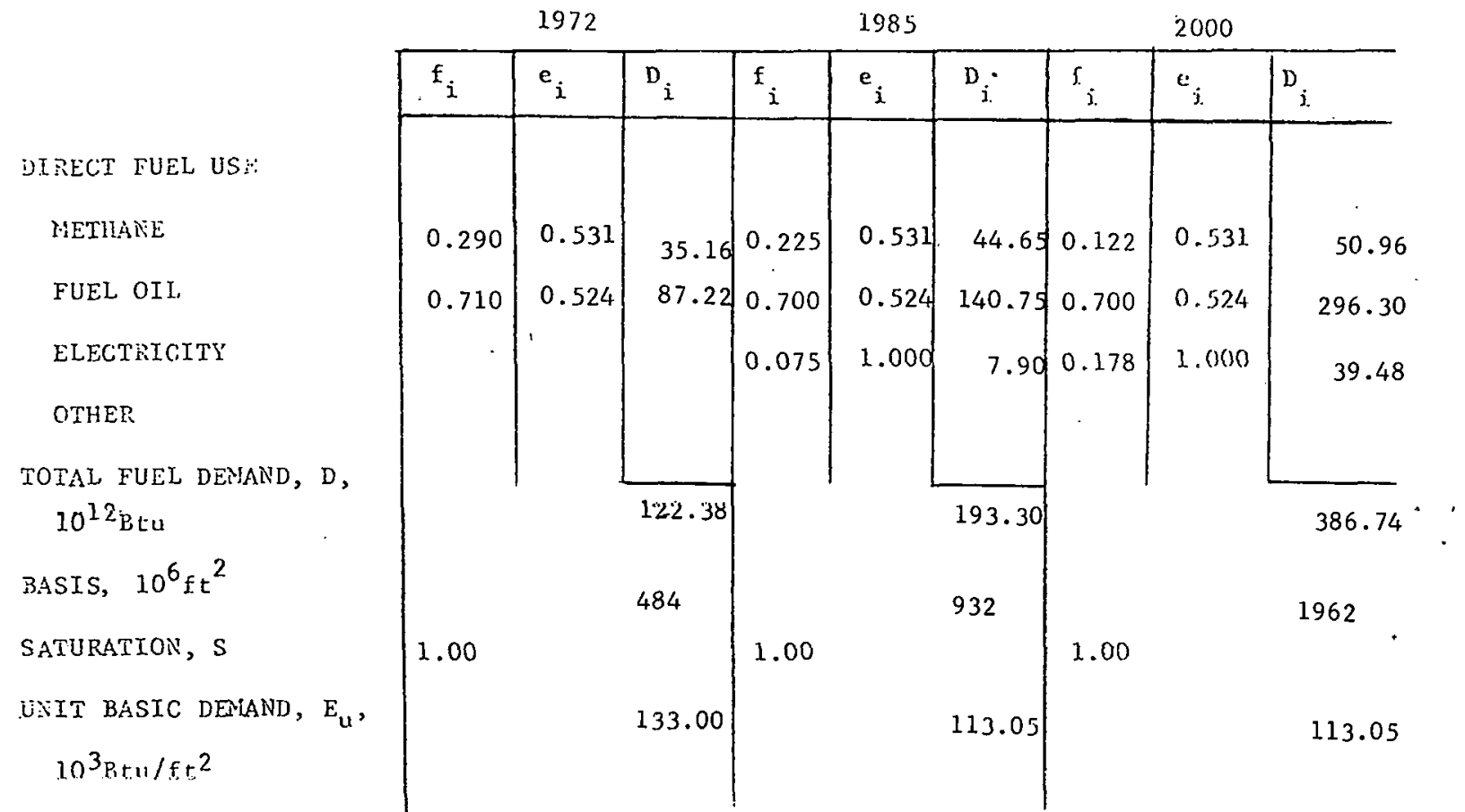

REFERENCE TECHNOIOGIES:

DATA SOURCES :

BASIS OF PROJECTIONS:

Note: For all Region III tables for the commercial sector, see corresponding Region I tables for reference technologies, data sources, and basis of projection. 
FUEL HCX TABIE

A-73

Reijicia: III

Scctor: COMMERCIAL

Catecory: RETAIL

End-use: SPACE HEATING

DTRECS FUEL USE

METHANE

FUEL OIL

ELECTRICITI

CTHER

TOTAL FUEL DENAND, D, $10^{12} \mathrm{Btu}$

BASIS, $10^{6} \mathrm{ft}^{2}$

SATURATION, $S$

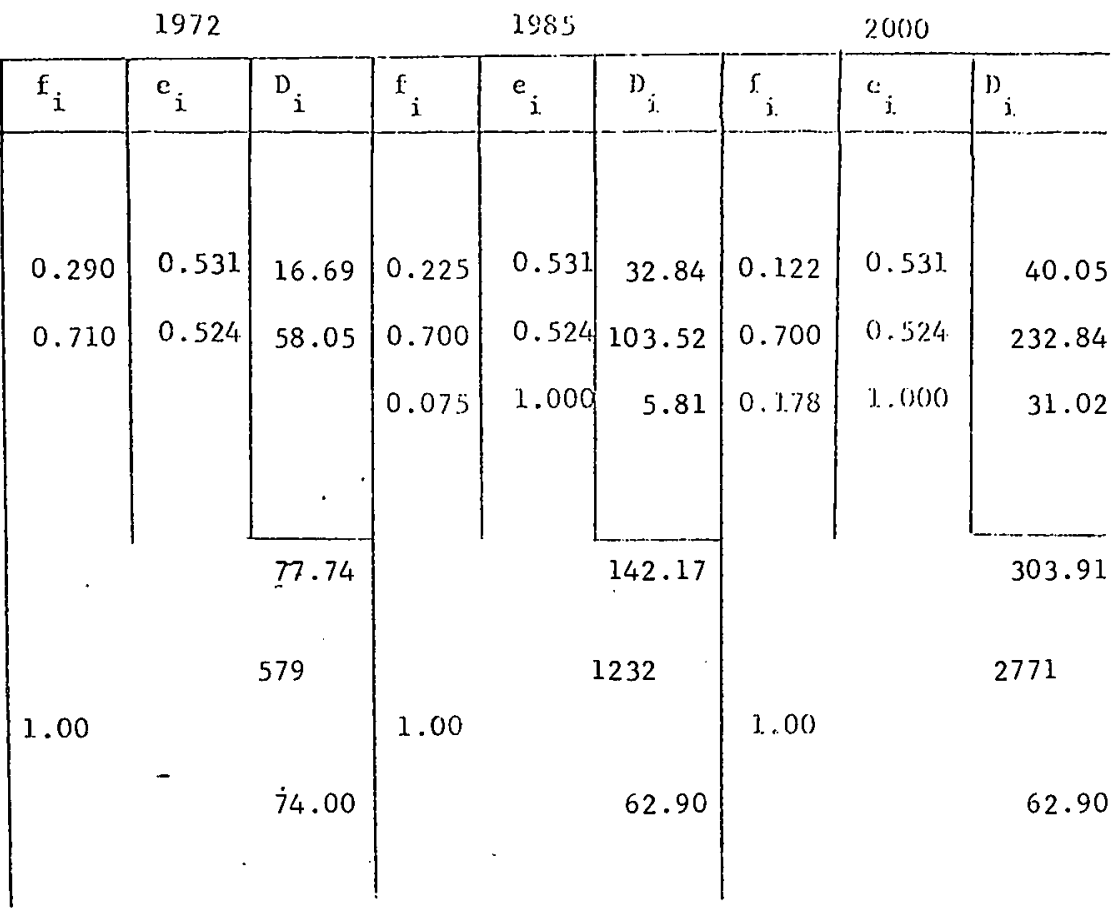

REFERENCE TECHNOLOGIJS:

DATA SOURCES:

BASIS OF PROJECTIONS: 
FUEL HIX "SABI.E

A-74

Reijion: III

Sector: COMMERCIAL

Category: SCHOOL

End-use: SPACE HEATING

\begin{tabular}{|c|c|c|c|c|c|c|c|c|c|}
\hline & \multicolumn{3}{|c|}{1972} & \multicolumn{3}{|c|}{1985} & \multicolumn{3}{|c|}{2000} \\
\hline & $\mathbf{f}_{i}$ & $e_{i}$ & $\mathrm{D}_{i}$ & $f_{i}$ & $e_{i}$ & $D_{j .}$ & ${ }_{j}$ & ${ }_{j}$ & ${ }^{\mathrm{D}}{ }_{\mathrm{i}}$ \\
\hline UTREC'T FUEI USE & & & & & & & & & \\
\hline WETHADE & 0.290 & 0.531 & 40.21 & 0.225 & 0.531 & 40.63 & 0.122 & $0.53]$. & 31.66 \\
\hline FUEL OIL & 0.710 & 0.524 & 99.77 & 0.700 & 0.524 & 128.09 & 0.700 & 0.524 & 184.10 \\
\hline DLECTRICITI' & & & & 0.075 & 1.000 & 7.19 & & & 24.53 \\
\hline OTHER & & & $\cdot$ & & & & & & \\
\hline $\begin{array}{l}\text { TOIAL FUEL DENAND, D, } \\
\quad 10^{12} \mathrm{BLU}\end{array}$ & & & 139.98 & & & 175.91 & & & 240.29 \\
\hline BISIS, $10^{6}$ It $^{2}$ & & & 624 & o & & 956 & & & 1374 \\
\hline SATURATIONI, S & 1.00 & & & 1.00 & & & ]. .00 & & \\
\hline $\begin{array}{l}\text { WAIT BASIC DFHAND, } \mathrm{E}_{\mathrm{u}} \\
10^{3} \mathrm{Btu} / \mathrm{ft}^{2}\end{array}$ & . & & 118.00 & & 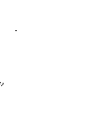 & 100.30 & & & 100.30 \\
\hline
\end{tabular}

REFERENCE TECHNOLOGIJS:

DETA SOUKCES:

BASIS OF PROJECTIONS: 
FIEI. MIX THBLE

$$
\text { A-75 }
$$

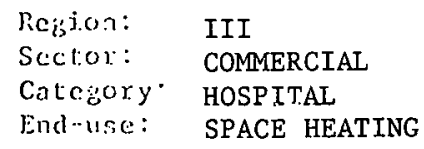

\begin{tabular}{|c|c|c|c|c|c|c|c|c|c|}
\hline & \multicolumn{3}{|c|}{1972} & \multicolumn{3}{|c|}{1985} & \multicolumn{3}{|c|}{2000} \\
\hline . & $\mathrm{f}_{i}$ & $e_{i}$ & ${ }^{D_{i}}$ & $\mathrm{f}_{\mathrm{i}}$ & $\epsilon_{i}$ & $\mathrm{D}_{\mathbf{i}}$ & ${ }_{j}$ & $c_{j}$ & ${ }^{\mathrm{D}}$ \\
\hline DIREC'I FUEL USE & & & & & & & & & \\
\hline METHANE & 0.290 & 0.531 & 14.49 & 0.225 & 0.531 & 16.93 & 0.1 .22 & $0.53]$. & 13.95 \\
\hline FUEL OIL & 0.710 & 0.524 & 42.71 & 0.700 & 0.524 & 53.37 & 0.700 & 0.524 & 81.10 \\
\hline ELECTRICITY & & & & 0.075 & 1.000 & 2.93 & 0.178 & 1.000 & 10.81 \\
\hline OTHER & & & & & & & & & \\
\hline $\begin{array}{l}\text { TOTAL FUEL DEMAND, D, } \\
10^{12} \mathrm{Btu}\end{array}$ & & & 57.20 & & & 73.23 & & & 105.86 \\
\hline BASIS, $10^{6} \mathrm{Ft}^{2}$ & & & 222 & & & 331 & & & 503 \\
\hline SATURATION, S & 1.00 & & . & 1.00 & & & 3.00 & & \\
\hline $\begin{array}{l}\text { : SNIT BASIC DENAND, } \mathrm{E}_{\mathrm{u}}, \\
10^{3} \mathrm{Btu} / \mathrm{ft}^{2}\end{array}$ & & & 142.00 & & & 120.70 & & & 120.70 \\
\hline
\end{tabular}

REFERENCE TECHNOLOGIES:

DATA SOURCES:

BASIS OF PROJECTIONS: 
FUEL TIX 'IABLE

A-76

Pegion: TII

Sector: COMMERCIAL

Calegory: MISCELLANEOUS

End-use: SPACE HEATING

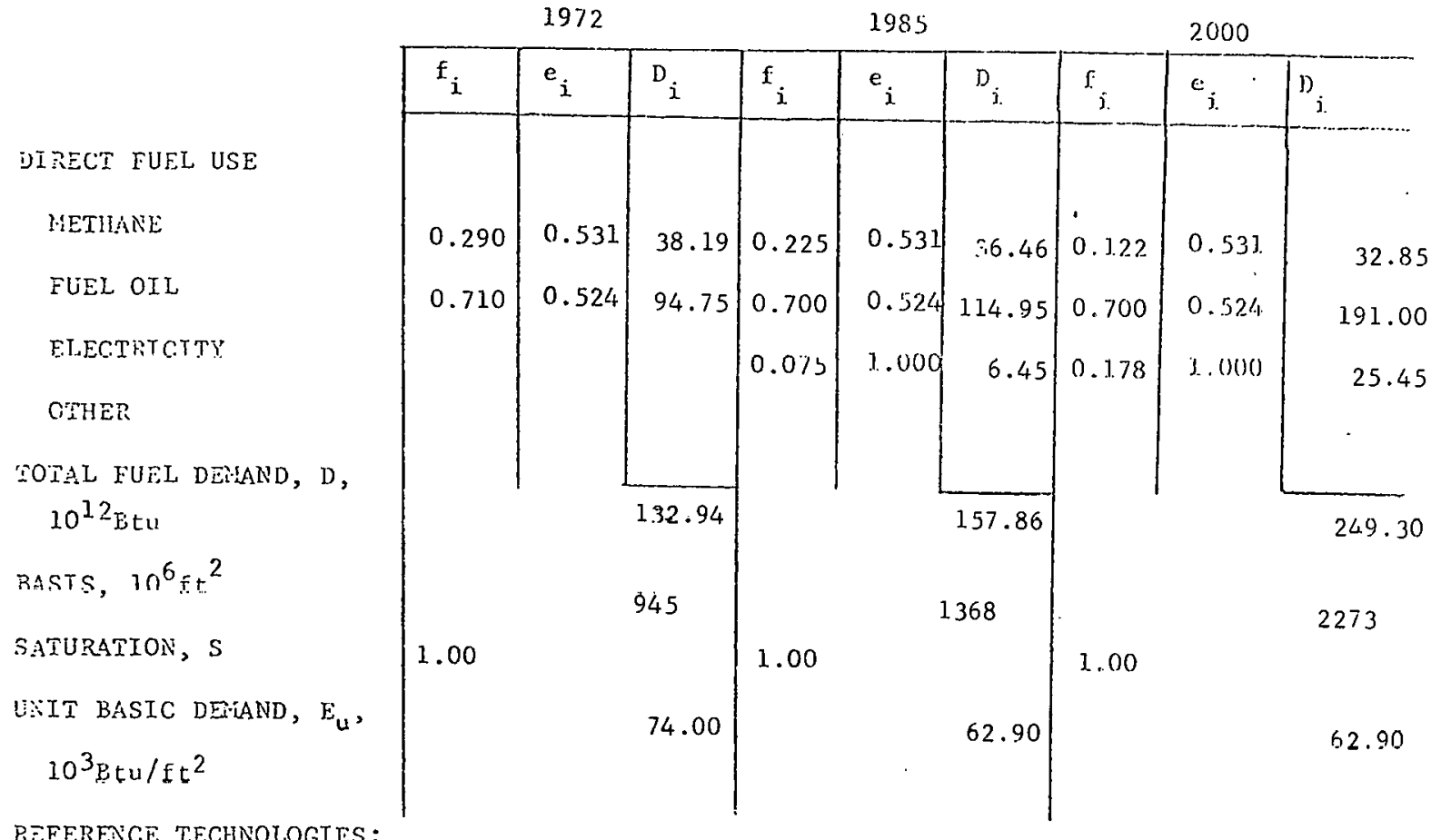

DATA SOURCES:

EASTS OF PROJECTIONS: 
FUEL MIX TABLE

A-77

Region: III

Sector: COMMERCIAI

Category: OFFICE

End-use: AIR CONDITIONING

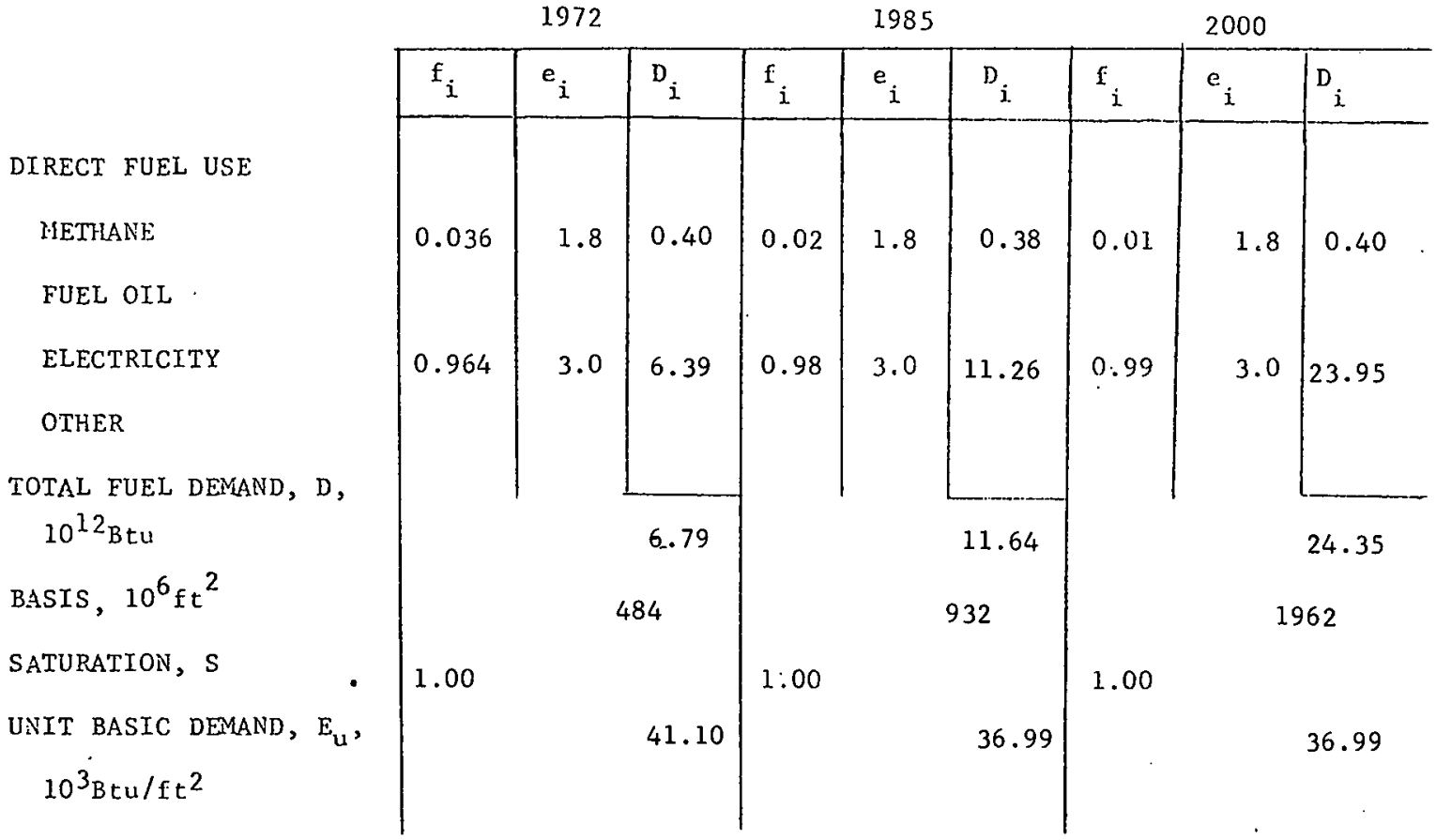

REFERENCE TECHNOLOGIES:

DATA SOURCES :

BASTS OF PROJECTIONS: 
FUEL MIX TABLE

$\mathrm{A}-78$

Region: III

Sector: COMMERCIAL

Category: RETAIL

Fnd-use: AIR CONDITIONING

\begin{tabular}{|c|c|c|c|c|c|c|c|c|c|}
\hline & \multicolumn{3}{|c|}{1972} & \multicolumn{3}{|c|}{1985} & \multicolumn{3}{|c|}{2000} \\
\hline & $f_{i}$ & $e_{i}$ & $\mathrm{D}_{\mathrm{i}}$ & $\mathrm{f}_{i}$ & $e_{i}$ & $D_{i}$ & $\mathrm{f}_{i}$ & $e_{i}$ & $D_{i}$ \\
\hline \multicolumn{10}{|l|}{ DIRECT FUEL USE } \\
\hline METHLANE & 0.036 & 1.8 & 0.53 & 0.02 & 1.8 & 0.57 & 0.01 & 1.8 & 0.64 \\
\hline FUEL OIL & & & & & & & & & \\
\hline ELECTRICITY & 0.964 & 3.0 & 8.54 & 0.98 & 3.0 & 16.63 & 0.99 & 3.0 & 37.78 \\
\hline OTHER & & & & & & & & & \\
\hline $\begin{array}{l}\text { TOTAL FUEL DENAND, D, } \\
10^{12} \mathrm{Btu}\end{array}$ & & & 9.07 & & & 17.20 & & & 38.42 \\
\hline BASIS $10^{6} \mathrm{ft}^{2}$ & & & 579 & & & 878 & & & 2771 \\
\hline SATURATION, S & 1.00 & & & 1.00 & & & 1.08 & & \\
\hline $\begin{array}{l}\text { UNIT BASIC DEMAND, } \mathrm{E}_{\mathrm{u}} \text {, } \\
10^{3} \mathrm{Btu} / \overline{\mathrm{f}} \mathrm{t}^{2}\end{array}$ & & & 45.90 & 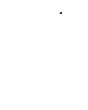 & & 41.31 & & & 41.31 \\
\hline
\end{tabular}

REFERENCE TECHNOLOGIES:

DATA SOURCES :

BASIS OF PROJECTIONS: 
FUEL MIX TABLE A-79

Region: III

Sector: CONTERCIAL

Category: SCHOOL

End-use: AIR CONDITIONING

DIRECT FUEL USE

METHANE

FUEL OIL

ELECTRICITY

OTHER

TOTAL FUEL DEMAND, D, $10^{12} \mathrm{Btu}$

BASIS $10^{6} \mathrm{ft}^{2}$

SATURATION, S

UNIT BASIC DEMAND, $E_{u}$, $10^{3} \mathrm{Btu} \mathrm{ft}^{2}$

REFERENCE TECHNOLOGIES:

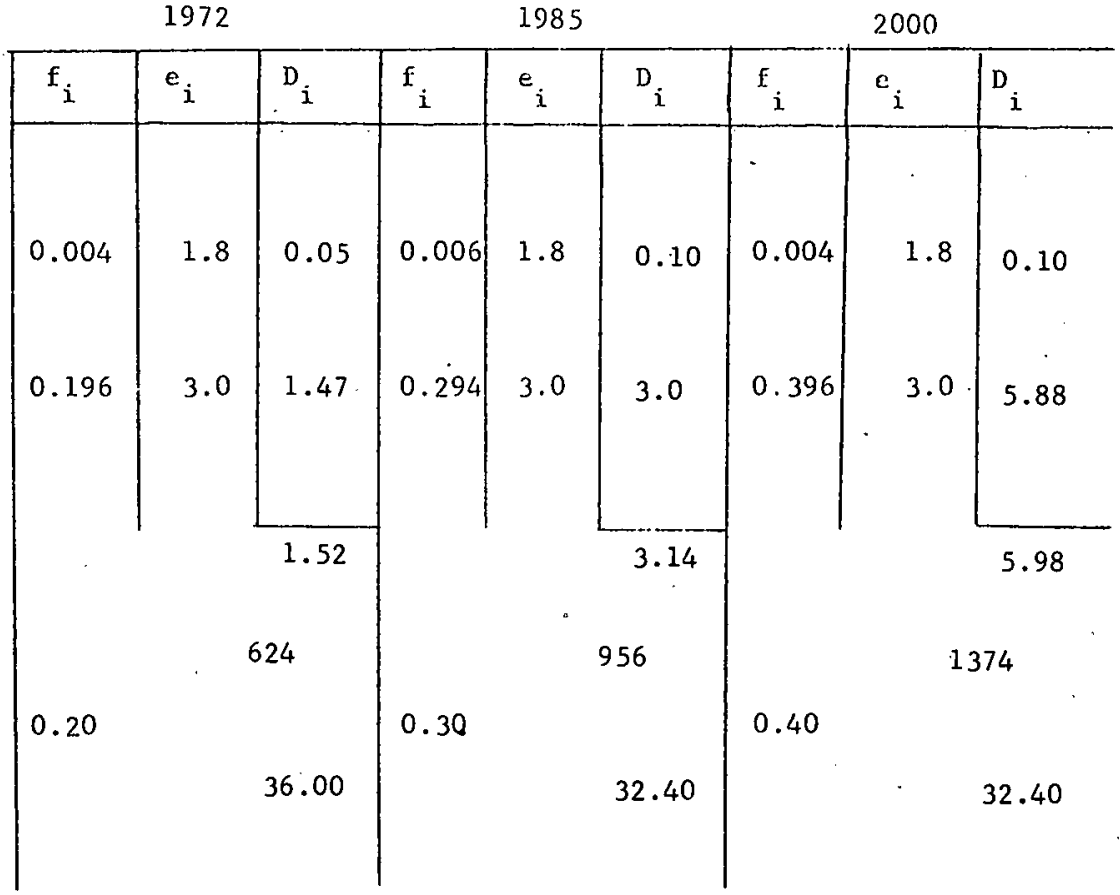

DATA SOURCES :

BASIS OF PROJECTIONS: 
FUEL MIX TABLE

$$
\text { A-80 }
$$

Region: III

Sector: COMMERCIAL

Category: HOSPITAL

End-use: AIR CONDITIONING

DIRECT FUEL USE

METHANE

FUEL OIL

ELECTRICITY

OTHER

TOTAL FUEL DEMAND, D, $10^{12} \mathrm{Btu}$

BASIS $10^{6} \mathrm{ft}^{2}$

SATURATION, S

UNIT BASIC DEMANn, $E_{u}$,

$$
1 n^{3} \mathrm{Btu} / \mathrm{Et}^{2}
$$

REFERENCE TECHNOLOGIES:

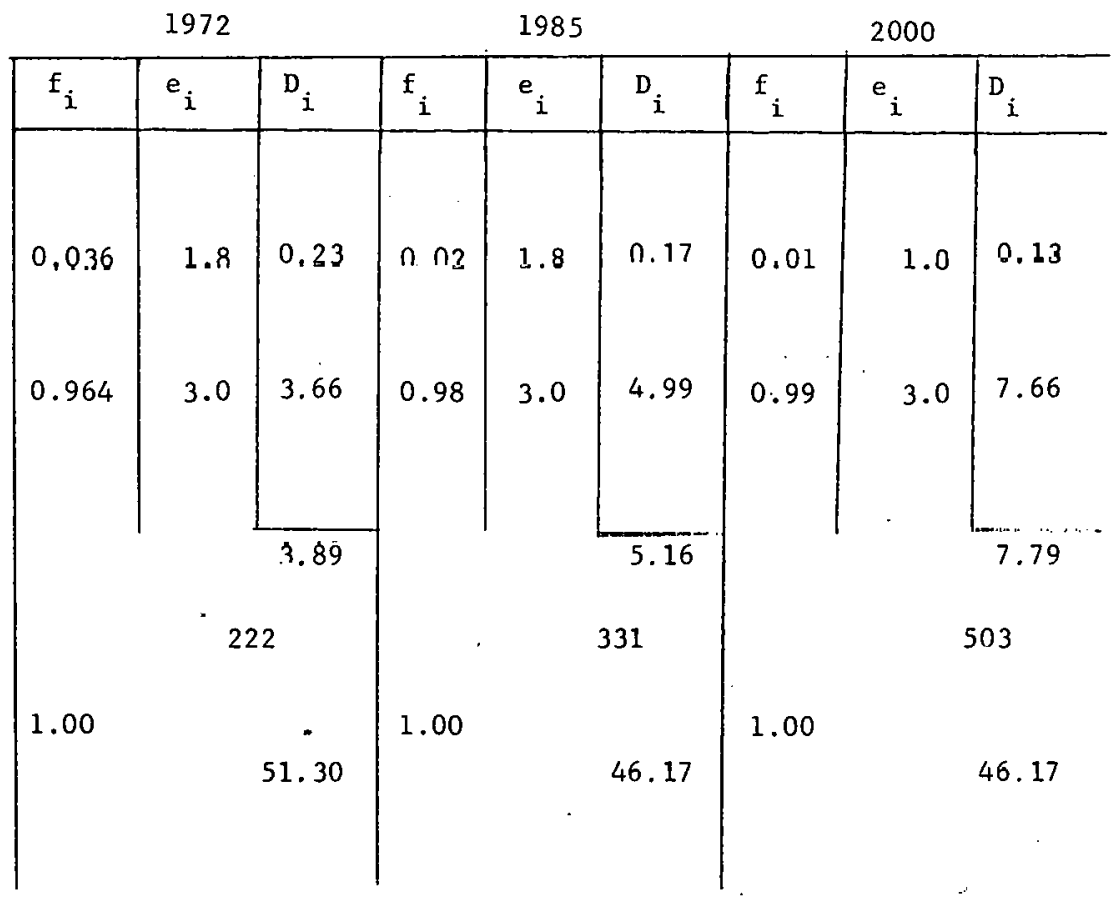

DATA 3OURCES:

BASIS OF PROJECTIONS: 
FUEL MIX TABLE

$\Lambda-81$

Region: III

Sector: COMMERCIAL

Category: MISCELLANEOUS

End-use: AIR CONDITIONING

DIRECT FUEL USE

METHANE .

FUEL OIL

ELECTRICITY

OTHER

TOTAL FUEL DEMAND, D, $10^{12}$ Btu

BASIS , $10^{6} \mathrm{ft}^{2}$

SATURATION, S

UNIT BASIC DEMAND, $E_{u}$, $10^{3} \mathrm{Btu} / \mathrm{ft}^{2}$

REFERENCE TECHNOLOGTES:

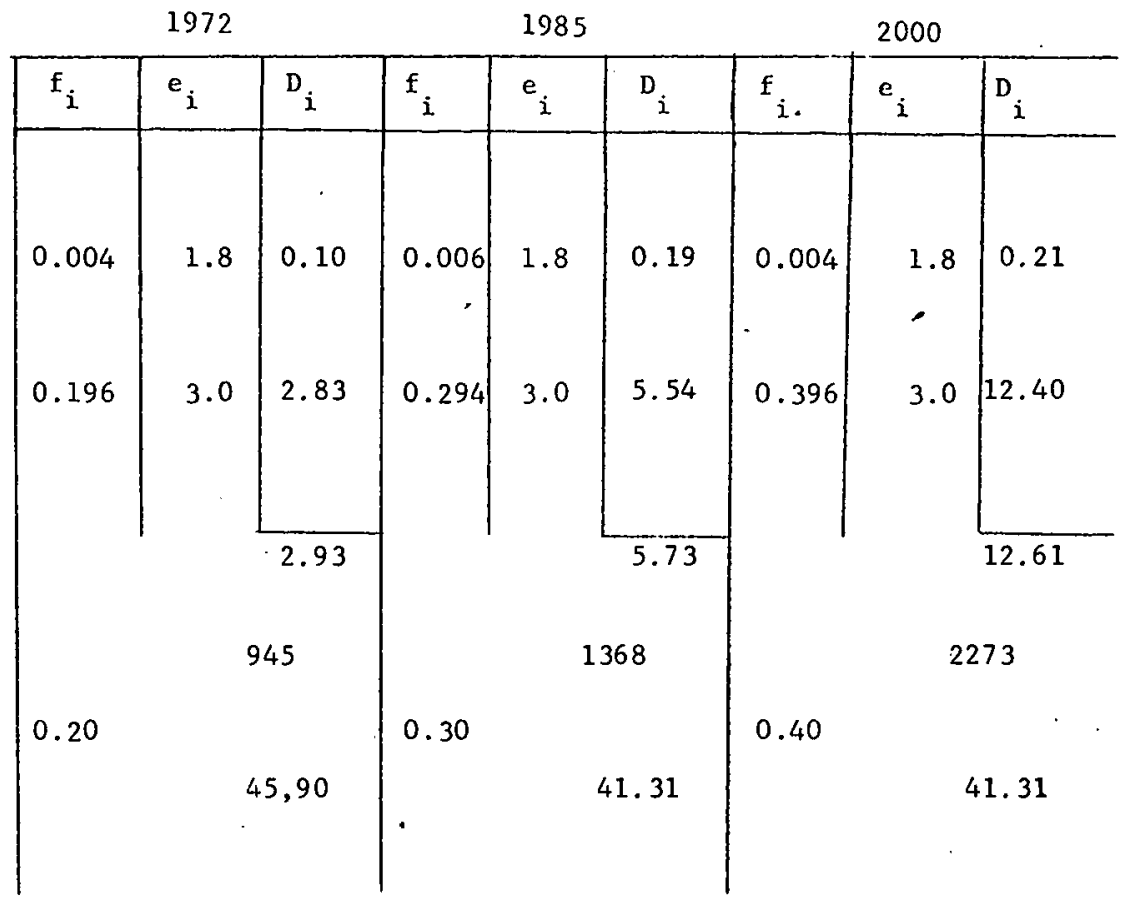

DATA SOURCES:

BASIS OF PROJECTIONS: 
FUEL MIX TABLE

A-82

Region: III

Sector: CONNERCIAL

Category: ALL BUILDINGS

End-use: WATER HFATING

\begin{tabular}{|c|c|c|c|c|c|c|c|c|c|}
\hline & \multicolumn{3}{|c|}{1972} & \multicolumn{3}{|c|}{$19 \dot{8} 5$} & \multicolumn{3}{|c|}{2000} \\
\hline - & $\mathrm{f}_{i}$ & $e_{i}$ & $D_{i}$ & $\mathrm{f}_{i}$ & $e_{i}$ & $\mathrm{D}_{\mathrm{i}}$ & $\mathrm{f}_{i}$ & $e_{i}$ & $D_{i}$ \\
\hline DIRECT FUEL USE & & & & & & . & & & \\
\hline $\begin{array}{l}\text { METHANE } \\
\text { FUEL OIL }\end{array}$ & 0.68 & 0.70 & 46.79 & 0.40 & 0.70 & 46.81 & 0.22 & 0.26 . & 47.46 \\
\hline $\begin{array}{l}\text { ELECTRICITY } \\
\text { OTHER }\end{array}$ & 0.32 & 1.00 & 15.59 & 0.60 & 1.00 & 49.15 & 0.78 & 1.00 & 217.79 \\
\hline $\begin{array}{l}\text { TOTAL FUEL DEMAND, D, } \\
10^{1 \dot{2}_{\text {Btu }}}\end{array}$ & & & 62.38 & & & 95.96 & & & 165.25 \\
\hline BASIS, $10^{6} \mathrm{ft}^{2}$ & & & 2855 & & & 4819 & & & 8883 \\
\hline SATURATION, $\mathrm{S}$ & 1.00 & & & 1.00 & & & 1.00 & & \\
\hline $\begin{array}{l}\text { UNIT BASIC DEMAND, E }{ }_{u}, \\
10^{3} \mathrm{BLu} / \mathrm{CL}^{2}\end{array}$ & & & 17.00 & & & 17.00 & & & $\begin{array}{l}17.00 \\
\ldots\end{array}$ \\
\hline
\end{tabular}

REFERENCE TECHNOLOGIES:

DATTA S̈OIRCES:

BASIS OF PROJECTIONS: 


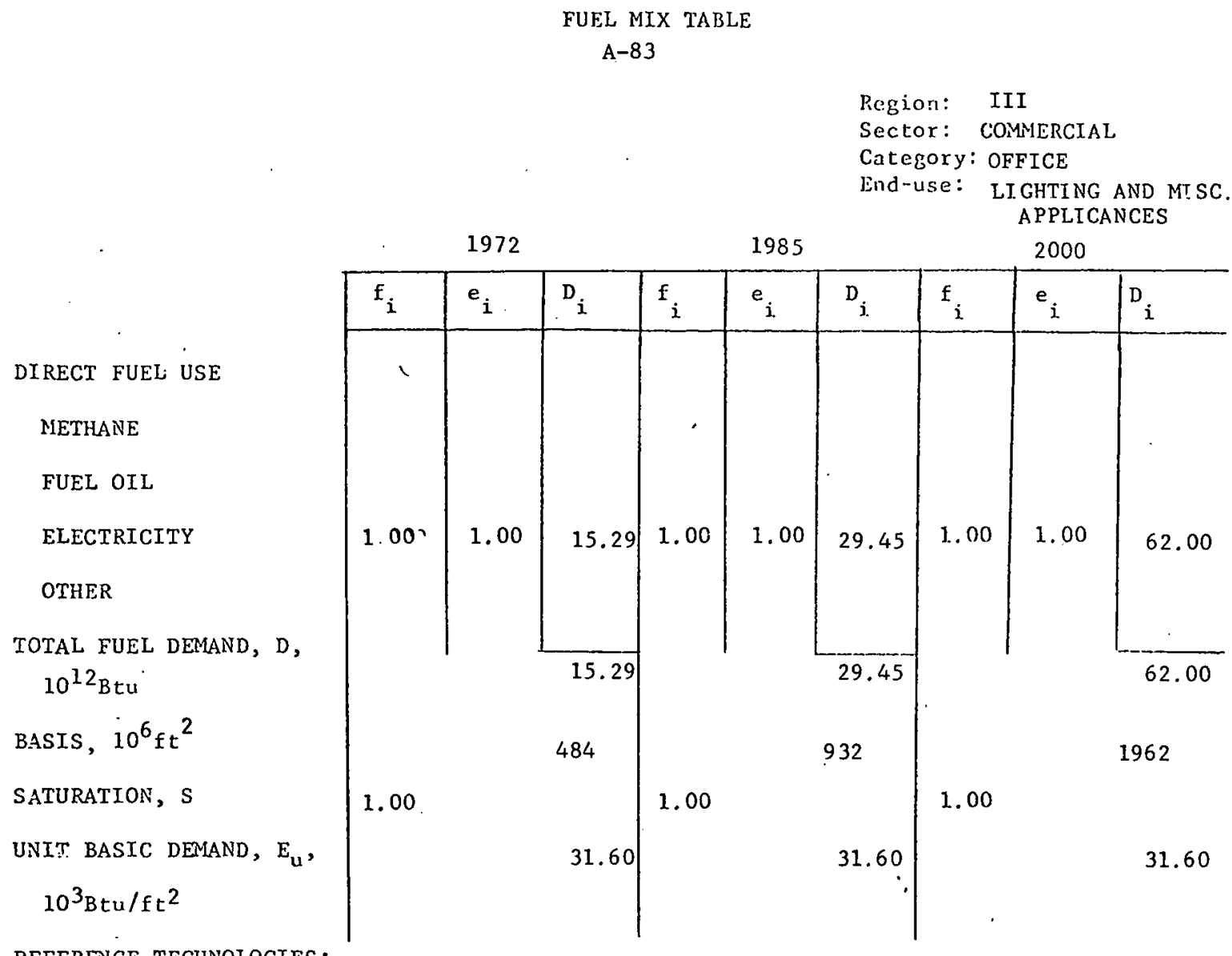

REFERENCE TECHNOLOGIES:

DATA SOURCES:

BASIS OF PROJECTIONS: 
FUIL MIX TABLE

A-84

Region: III

Sector: COMERCIAL

Category: RETAIL

End-use: LIGHTING NND MISC. APPLICANCES

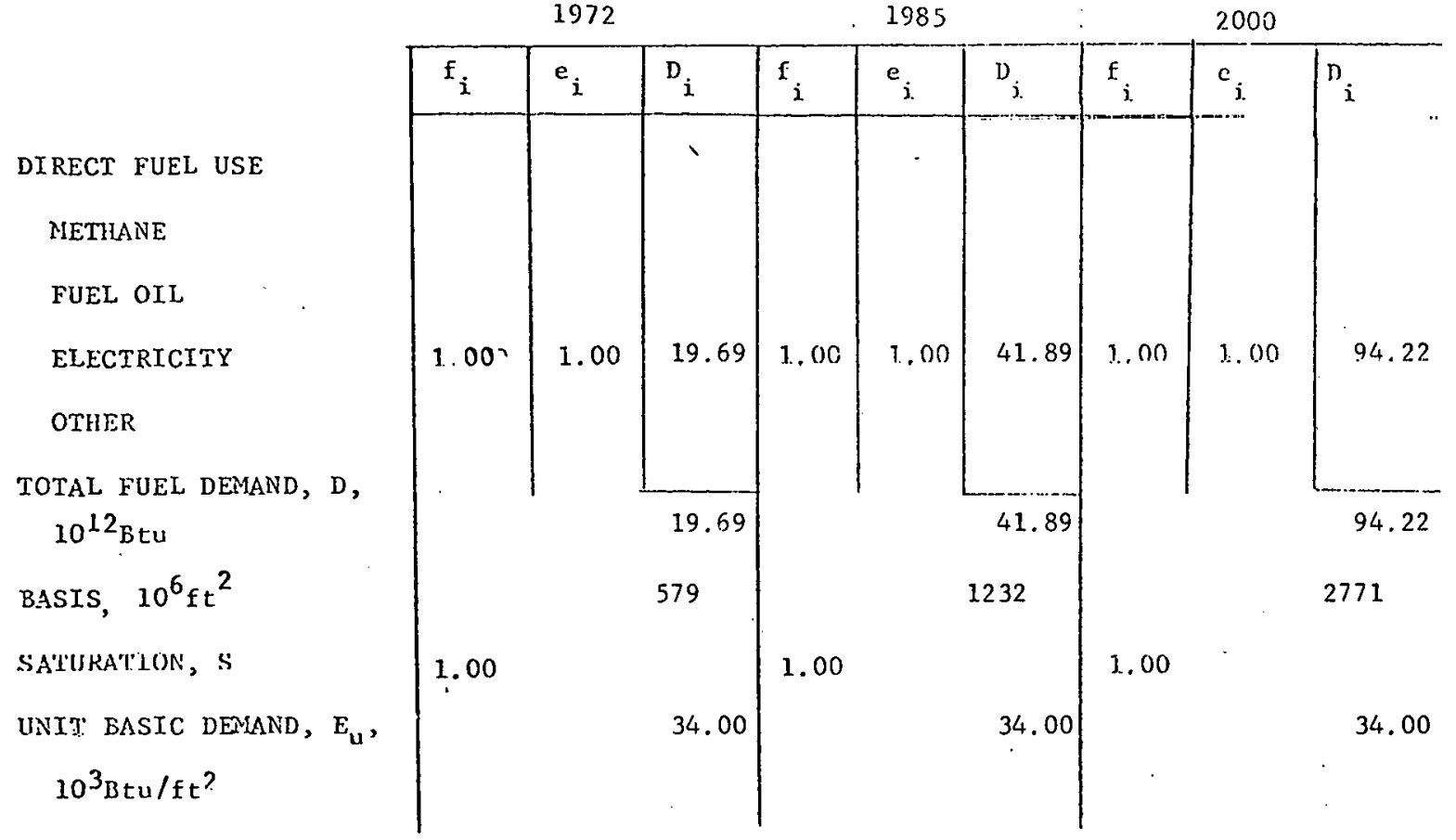

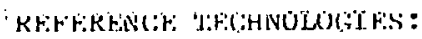

DATA SOURCES:

RASTS OF PROTECTTONS: 
FUI:L MIX TABLE:

A -85

DIRECT FUEL USE

METHANE

FUEL OIL

ELECTRICITI

OTHER

TOTAL FUEL DEUIAND, D, $10^{12} \mathrm{Btu}$

BASIS, $10^{6} \mathrm{ft}^{2}$

SATURATION, S

UNIT BASIC DENLND, $\mathrm{E}_{\mathbf{u}}$,

$$
10^{3} \mathrm{Btu} / \mathrm{ft}^{2}
$$

REFERENCE TECHNOLOGIES:

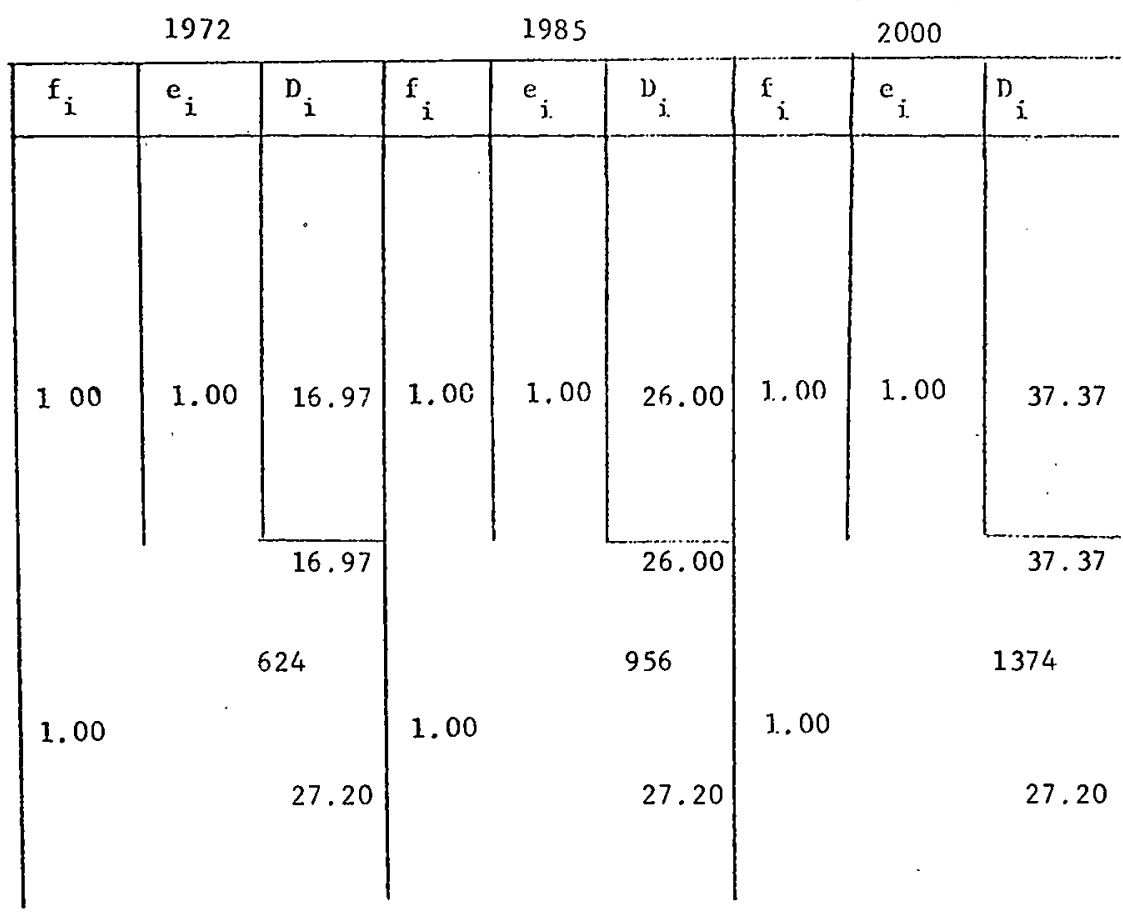

DATA SOURCES:

BASTS OF PROJECTIONS:

Region: III

Sector: COMNERCIAI

Colegrory: SCHOOL

End-use: LJGHTING AND MISC. APPI_TCANCES 
WHE HIX jAlit:

$$
\text { A-86 }
$$

Regi,jon: III

Sector: COMHERCIÁ,

Caterory: HOSPITAL

Bnd-uge: DJGHTING AND MISC. APPLICANCES

DIRECT FUEL USE

METHANE

FUEL OIL

ELECTRICITY

OTHER

COTAL FUEL DEMAND, J), $10^{12} \mathrm{Btu}$

BAEIC, $10^{6} \mathrm{CL}^{2}$

SATUPATION, S

1972

1985

2000

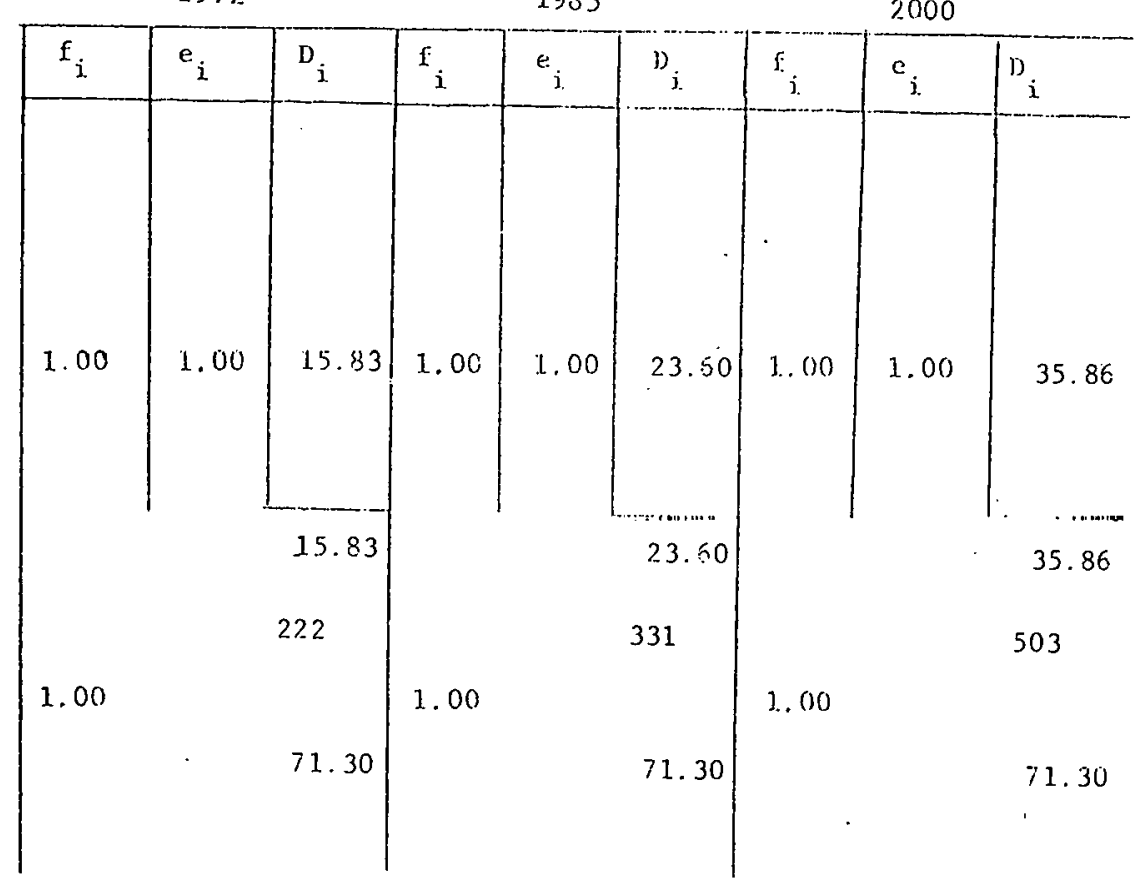

REFERE!CE TECHNOLOGTES:

DATA SOURCES:

BASIS OF PROJECTIONS: 


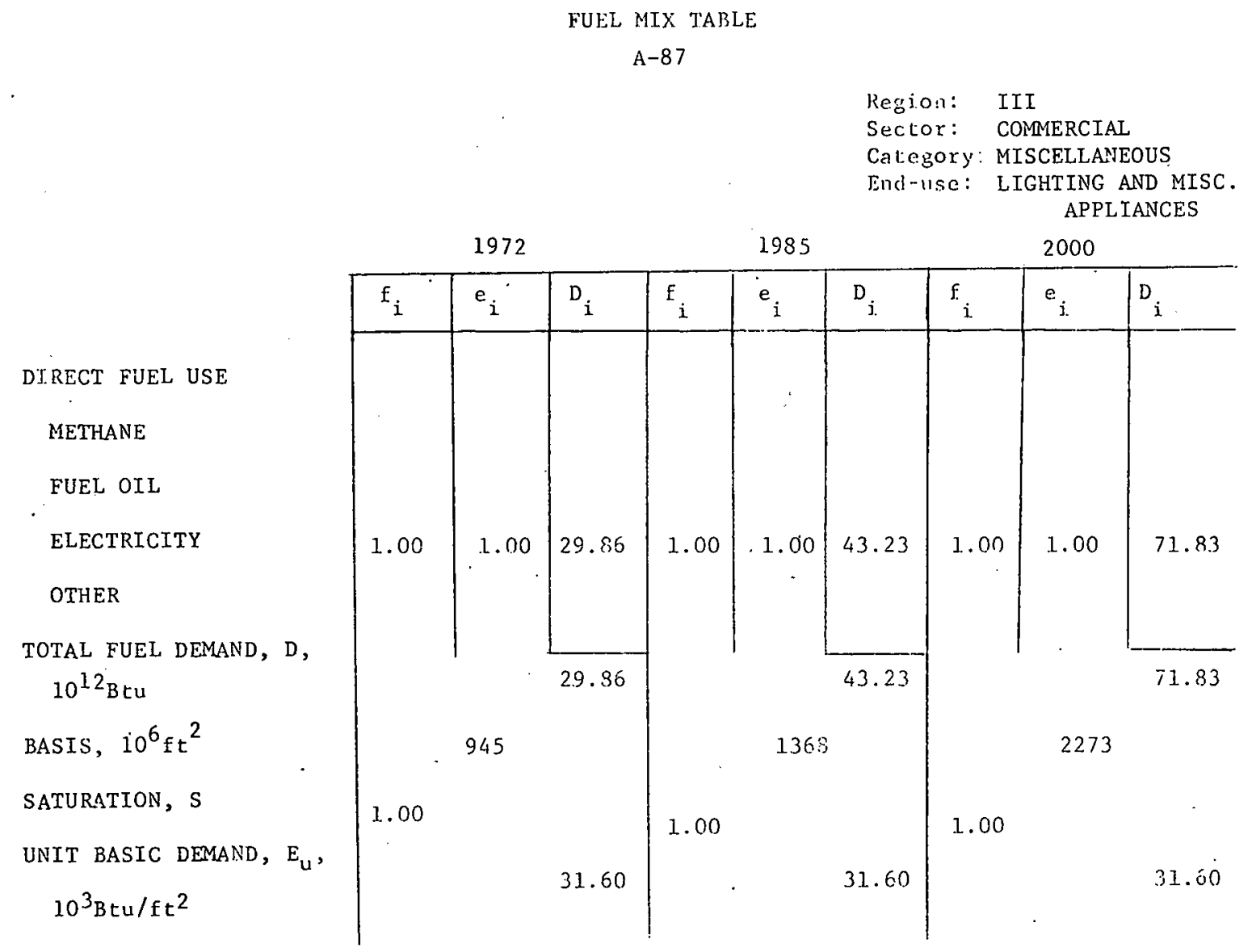

REFERENCE TECHNOLOGIES:

DATA SOURCES :

BASIS OF PROJECTIONS: 


\section{THIS PAGE \\ WAS INTENTIONALLY \\ LEFT BLANK}


APPENDIX B

MODE SHIFT ANALYSIS

In addition to the projections based on assumptions described in section IV, projections exploring the possibilities for shifts between energy forms were made for use in supply-demand analysis in the Northeast Energy Perspectives study. Such mode shifts may indicate a decrease in total energy demand of several percent; however, such reductions must be interpreted judiciously. A shift to electricity may reduce end-demand energy requirements but increase thermal energy input requirements in a supply sector. The principal advantage of a mode shift lies in the resulting change in demand for specific fuels, not in the change in total demand.

\section{Mode Shift to Electricity}

For each of the three cases developed in section IV, a corresponding case was constructed with a mode shift to electricity. For these cases, it is assumed that a larger portion of new homes are electrically heated because of restrictions on gas and oil supplies. In this mode shift, $50 \%$ of the homes built between 1972 and 1985 and $75 \%$ of those built thereafter are assumed to be electrically heated. Furthermore, it is assumed that half of the existing stock of warm air furnaces that must be replaced within the projection period are replaced with electric units. In the commercial sector, it is assumed that electricity is used for heating in twice as many units as in the non-mode shift case. The amounts of oil and natural gas replaced by electricity are assumed to be proportional to the relative market share of each fuel in the non-mode shift case. The result is shown in Table $B-1$. 
TABLE $B-1$

NORTHEAST RESIDENTIAL AND COMMERĆCIAL ENERGY

DEMAND $\left(10^{12} \mathrm{Btu}\right)$ MODE SHIFT TO

ELECTRICITY

\begin{tabular}{|c|c|c|c|c|c|c|}
\hline \multirow[b]{2}{*}{ Fuel type } & \multicolumn{3}{|c|}{1985} & \multicolumn{3}{|c|}{2000} \\
\hline & Base & Moderate & Strong & Base & Moderate & strong \\
\hline Oil & 2816 & 2513 & 2061 & 3567 & 2838 & 2027 \\
\hline Gas & 1403 & 1261 & 1043 & 1280 & 1066 & 791 \\
\hline Hiectrlctey & 1398 & 1227 & 1070 & 2812 & 2191 & 1667 \\
\hline solar & - & - & 25 & - & 370 & 631 \\
\hline
\end{tabular}

Mode Shift to Electricity and Gas

The rationale for this mode shift was a desire to see to what extent a shift to electricity and gas, supported by production of low Btu gas, could alleviate the high oil demands. For each of the iriginal three cases (Section IV) an alternative has been constructed in which gas retains its 1972 market share for space heating and electricity use is projected on the same basis as in the mode shift to electricity cases. Solar energy, if used; remains at its original levels and oil is used for the romaining demand.

Mode Shift to Oil and Gas

In this case, the possibility was explored that a high relative cost of electricity would reduce its use for heating in new buildings to half the level projected in the original reference case. The remaining demands for space heat are met with gas and oil in proportion to their use in the reference case. 
TABLE $\quad B-2$

NORTHEAST RESIDENTIAL AND COMMERCIAL ENERGY: DEMAND$\left(10^{12} \mathrm{Btu}\right)$ MODE SHIFT TO ELECTRICITY AND GAS

\begin{tabular}{|c|c|c|c|c|c|c|}
\hline \multirow[b]{2}{*}{ Fuel type } & \multicolumn{3}{|c|}{1985} & \multicolumn{3}{|c|}{2000} \\
\hline & Base & Moderate & Strong & Base & Moderate & Strong \\
\hline Oil & 2517 & 22.55 & 1851 & 2954 & 2177 & 1562 \\
\hline Gas & 1739 & 1555 & 1290 & 2147 & 1745 & 1287 \\
\hline Electricity & 1398 & 1227 & 1070 & 2812 & 2191 & 1667 \\
\hline Solar & - & - & 25 & - & 370 & 631 \\
\hline
\end{tabular}

TABLE B-3

NORTHEAST RESIDENTIAL AND COMMERCIAL ENERGY DEMAND$\left(10^{12}\right.$ Btu) MODE SHIFT TO OIL AND GAS

\begin{tabular}{|c|c|c|c|c|c|c|}
\hline \multirow[b]{2}{*}{ Fuel type } & \multicolumn{3}{|c|}{1985} & \multicolumn{3}{|c|}{2000} \\
\hline & Base & Moderate & strong & Base & Moderate & strong \\
\hline Oil & 3164 & 2807 & 2299 & 4552 & 2568 & 2529 \\
\hline Gas & 1460 & 1318 & 1089 & 1397 & 1163 & 849 \\
\hline Electricity & 1231 & 1091 & 968 & 2330 & 1851 & 1447 \\
\hline Solar & - & - & 25 & - & 370 & 631 \\
\hline
\end{tabular}

All the above cases attest to the region's very great dependence on oil for its energy source. Only in the case in which strong conservation is coupled with a mode shift to electricity and gas does the level of oil demand remain fairly constant over time. 
THIS PAGE

WAS INTENTIONALLY

LEFT BLANK 
REFERENCES

1. U.S. Departments of Commerce and Agriculture, 1972 OBERS Projections: Economic Activity in the U.S., Vol. 1 and 4, Washington, D.C., 1974. (OBERS, Office of Business Economics, USDC, and Economic Research Service, USDA.)

2. J. Lee, Energy Supply and Demand in the Northeast United States, Informal Report BNL 20427, sept. 1975.

3. U.S. Department of Commerce, Bureau of the Census, Detailed Housing Characteristics, 1970: Northeastern United States, Washington, D.C., April 1972.

4. U.S. Department of Commerce, U.S. Statistical Abstract, 1972 , Washington, D.C., 1972 .

5. Energy Policy Project of the Ford Foundation, A Time To Choose America's Energy Future, Ballinger Publishing Co., Cambridge, Mass., 1974.

6. Arthur D. Little, Inc., Project Independence Task Force Report: Residential and Commercial Energy Use Patterns, 1970-1990, Prepared for the Federal Energy Administration, washington, D.C., 1974 .

7. M. Tyson, Residential Heat Load Calculations for the Northeast, Informal Report $B N L$, in preparation.

8. 1974 statistical and Marketing Report, Merchandising Week, Billboard Publications, New York.

9. M. Marmor, Energy Conservation Scenarios for the Northeast United States, Informal Report BNL 20783, Deci. 1975.

10. Federal Power Commission, Measures for Reducing Energy Consumption for Homeowners and Renters, Washington, D.C., March 1975.

11. Press release, American Bocicty Heating, Refrigerating, and Air-Conditioning Engineers, New York, Aug. 13, 1975.

12. C.A. Berg, Conservation via Effective Use of Energy at the Point of Consumption, National Bureau of Standards, U.S. NBS IR 73-202, washington, D.C. April 11, 1973. 
13. A.L. Berlad and J. Batey, Performance evaluation and economic impact of oil-fired residential heating, Urban Analysis 1 , 95-104 (1972).

14. R. Socolow, Princeton University, Private communication to V. Sailor, BNL.

15. A.L. Berland, State University of New York at Stony Brook, Private communication to V. Sailor, BNL.

16. Westinghouse special systems, solar Heating and cooling of Buildings: Executive Summary, Westinghouse Electric Corp. Baltimore, Maryland, May 1974.

17. General Electric Co., Solar Heating and cooling of Buildings: Feasibility and Planning Study, General Electric Co.., Philadelphia, May 1974. 


\section{THE BROOKHAVEN NATIONAL LABORATORY REGIONAL ENERGY STUDIES PROGRAM}

The Brookhaven National Laboratory Regional Energy Studies Program is part of a national effort supported by the U.S. Energy Research and Development Administration (ERDA) to create an energy assessment capability which is sensitive to regional conditions, perceptions, and impacts. Within ERDA, this program is supported by the Division of Biomedical and Environmental Research and includes, in addition to a concern for health and environmental impacts of energy systems, analysis of the complex trade-offs between economics, environmental quality, technical considerations. national security, social impacts, and institutional questions. The Brookhaven Program focuses on the Northeast, including the New England states. New York, Pennsylvania, New Jersey, Maryland, Delaware, and the District of Columbia. The content of the program is determined through an identification of the major energy planning issues of the region and in consultation with state and regional agencies. A major component of the program in 1976 is the Northeast Energy Perspectives Study which examines the implications of alternative energy supply-demand possibilities for the region.

$$
y^{\prime \prime}
$$

